\title{
PERCEPTIONS OF ISLAMIC ADVERTISING HELD BY INDONESIAN MUSLIMS
}

BY

ANYA SAFIRA

\begin{abstract}
A thesis
submitted to the Victoria University of Wellington

in fulfilment of the requirements for the degree of

Master of Commerce in Marketing
\end{abstract}

Victoria University of Wellington

2017 



\begin{abstract}
In the past decades, research on the link between advertising and religion has been increasing (Cader, 2015). There is an especially growing interest in researching Islam, either in comparison with other religions (A. J. Ali \& Gibbs, 1998; Fam, Waller, \& Erdogan, 2004; Farah \& El Samad, 2014; Gibbs \& Ilkan, 2008) or as the focus of the research (Cader, 2015; Haque, Ahmed, \& Jahan, 2010). However, previous research on the topic of Islamic advertising has been dominated by conceptual papers and research conducted in Middle Eastern contexts (Bari \& Abbas, 2011; Hassan, Chachi, \& Latiff, 2008; Rice \& Al-Mossawi, 2002; Mohammad Saeed, Ahmed, \& Mukhtar, 2001). Therefore, this study has the objective of gaining a greater understanding of the perceptions of Islamic advertising to Indonesian Muslim consumers, including the interactions between religion and culture, congruency with their identity, and effects on attitudes and behaviour. Using the paradigm of critical realism, this research used a qualitative approach by gathering data through in-depth interviews. The findings identified five elements which constitute Islamic advertising in the eyes of Indonesian Muslims. These include compliance with Sharia (Islamic law), existence of universal Islamic values, relevant execution strategies, advertisement of "Islamic" products and brand, and the use of "Islamic" public figures as celebrity endorsers. Moreover, Indonesian Muslims tend to negotiate between their culture and religion which presents a challenge to the standardisation vs localisation debate in advertising. Islamic advertising was also found to be congruent with the Indonesian Muslims' identity, particularly those with higher religiosity, and induces positive effects on their emotions, attitudes and behaviour. An especially important impact for collectivist cultures such as Indonesia is that Islamic advertising is able to generate positive word-of-mouth.
\end{abstract}




\section{Table of Contents}

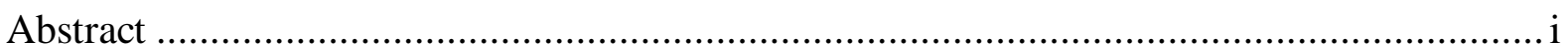

Chapter 1. Introduction ....................................................................................... 1

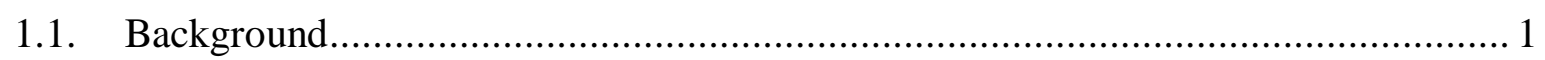

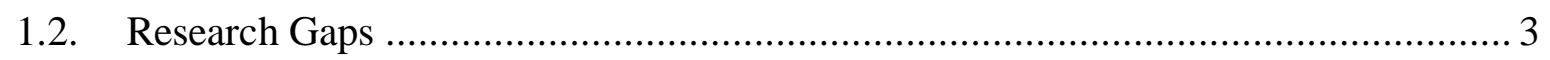

1.3. Research Contributions ......................................................................... 4

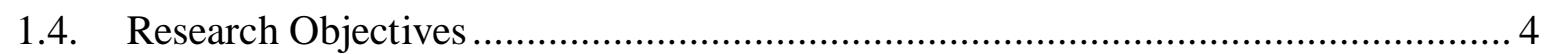

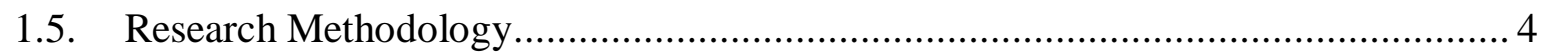

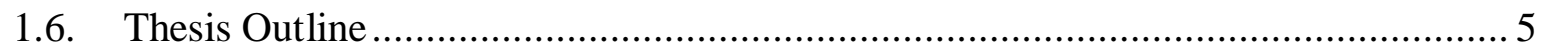

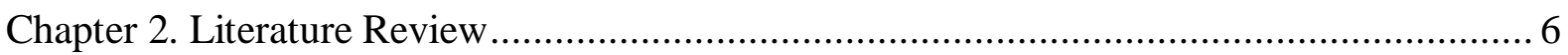

2.1. The Standardisation versus Localisation Debate ................................................ 6

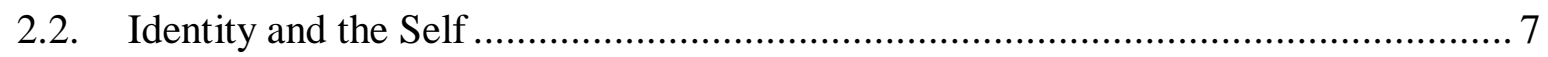

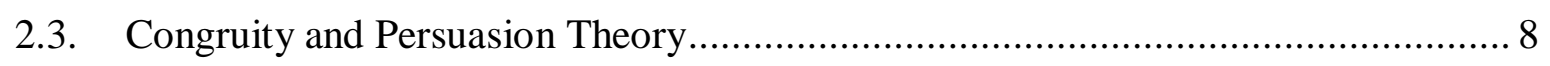

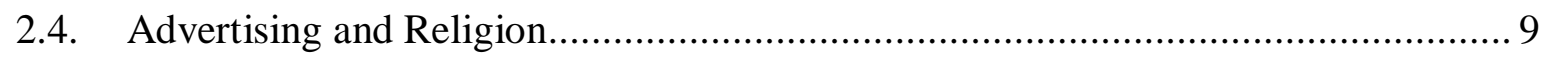

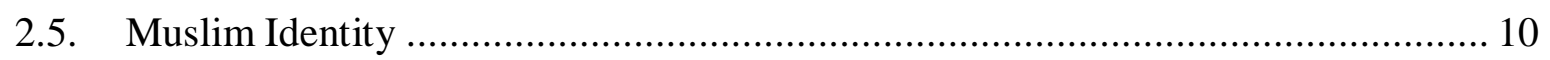

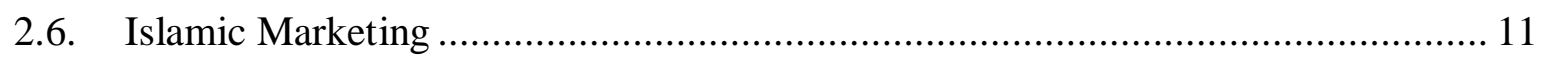

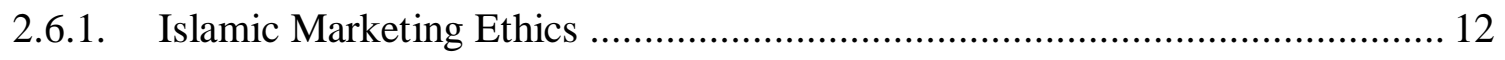

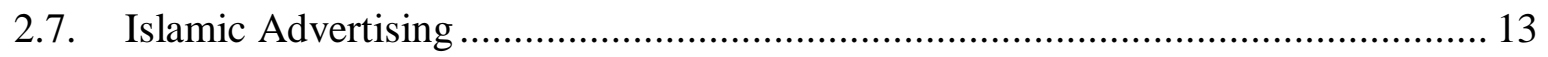

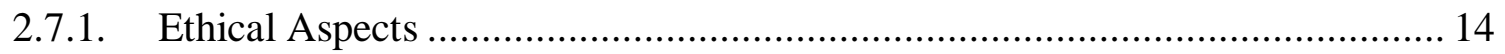

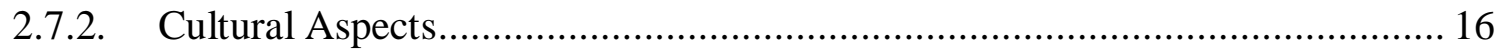

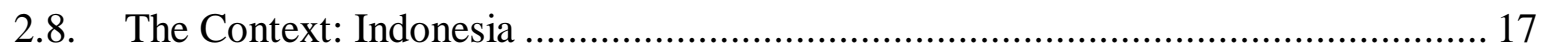

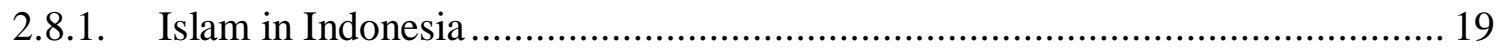

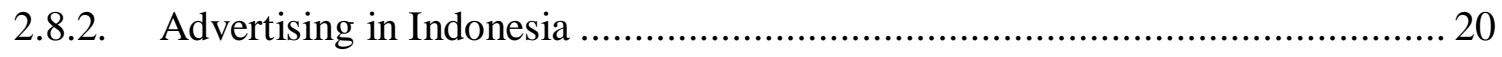

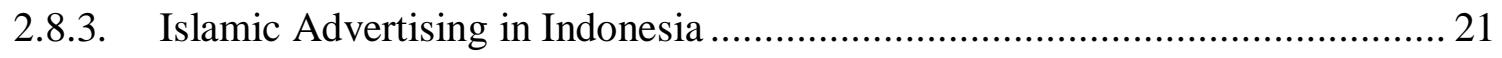

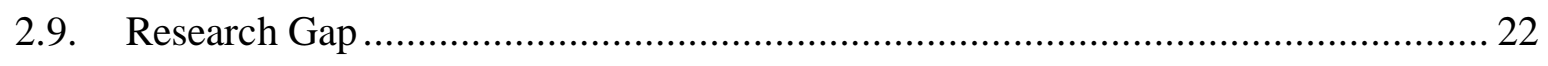

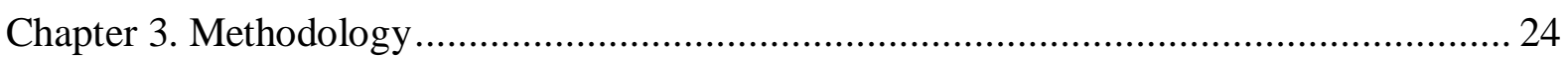




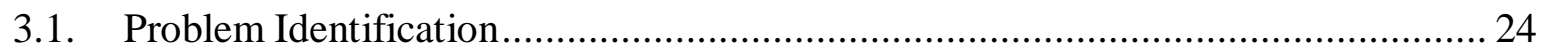

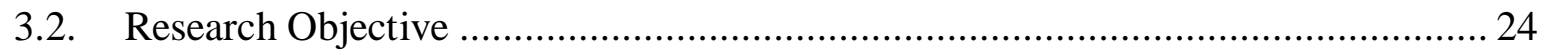

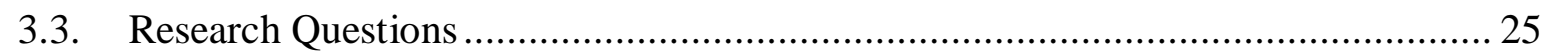

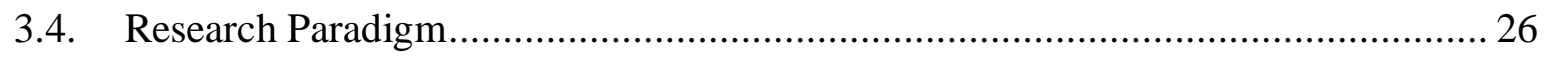

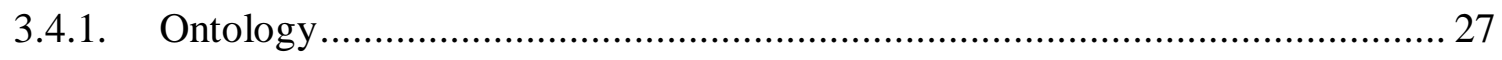

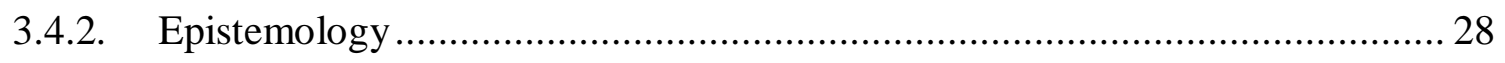

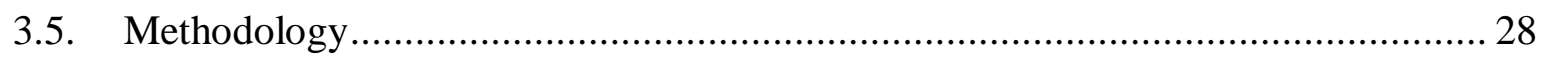

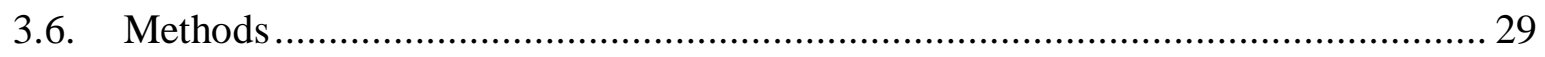

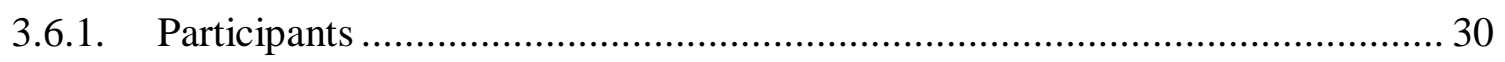

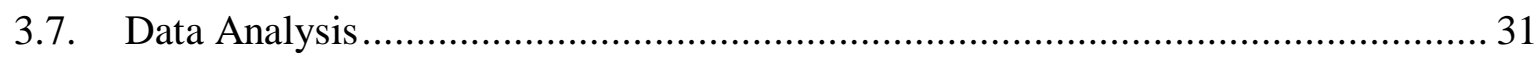

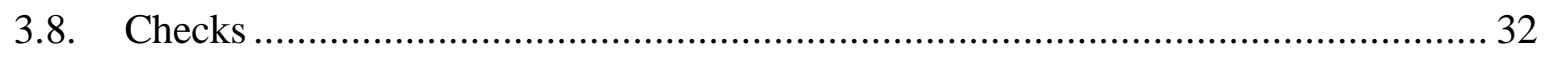

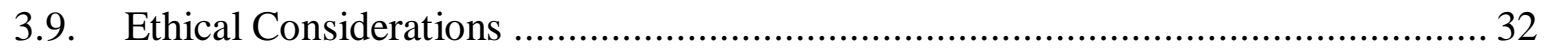

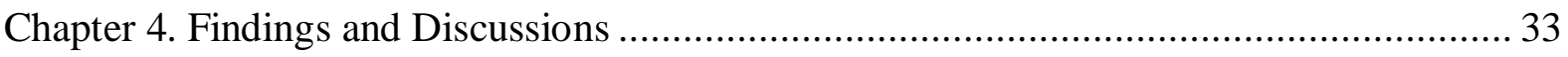

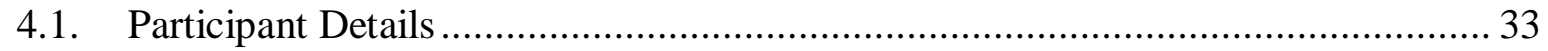

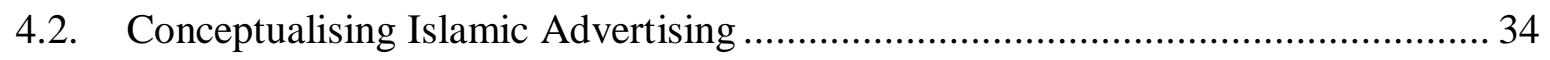

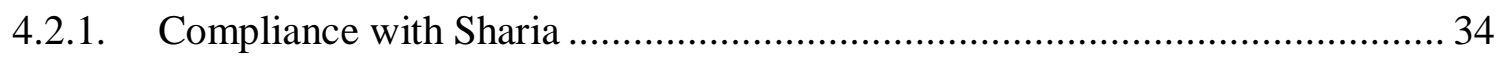

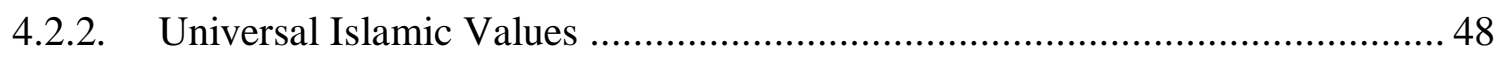

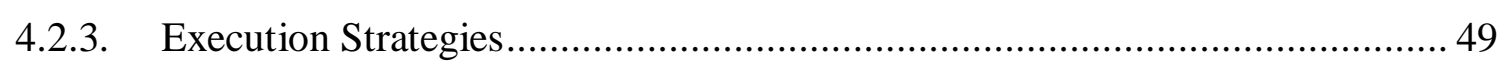

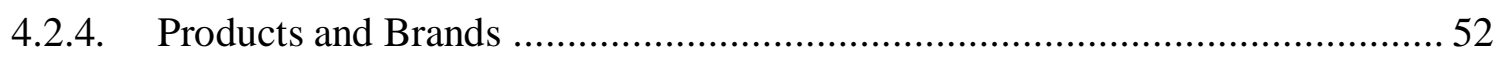

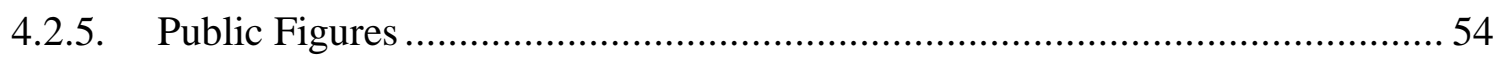

4.3. Negotiating Religion and Culture …..................................................... 57

4.4. A Challenge to the Standardisation versus Localisation Debate ............................ 60

4.4.1. Gaining Inspiration from Thai Advertisements ......................................... 61

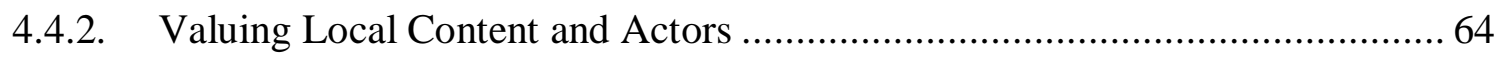

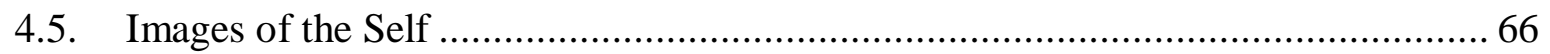

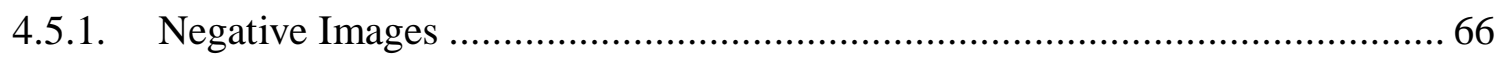

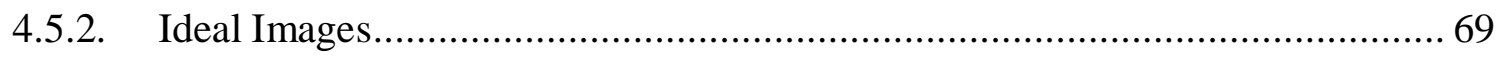




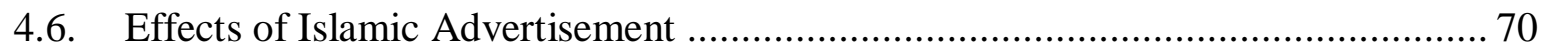

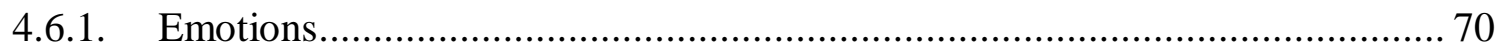

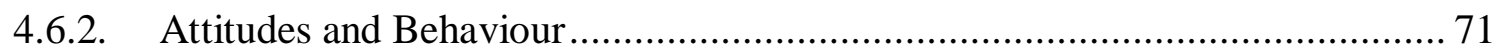

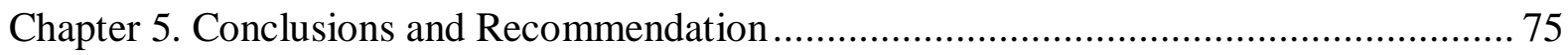

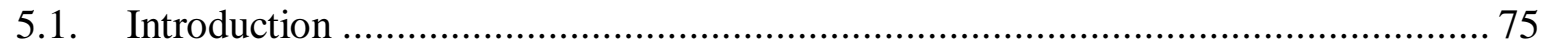

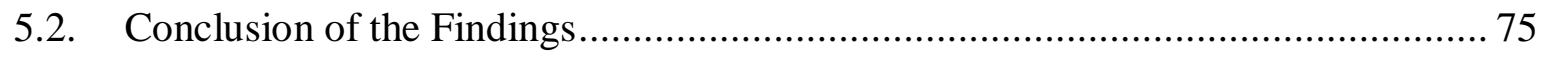

5.2.1. Adapting to the Principles of Islamic Values ............................................ 76

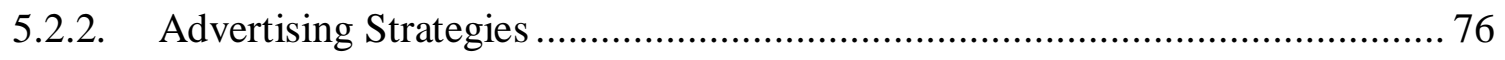

5.2.3. "Islamic" Imaged Products, Brands, and Celebrities.................................... 76

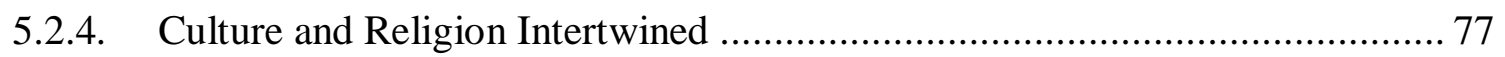

5.2.5. The Discourse on Standardisation versus Localisation.................................. 78

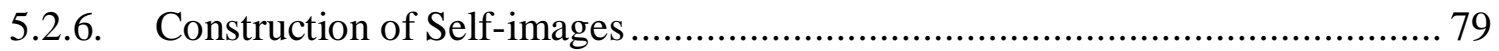

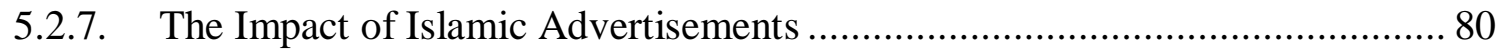

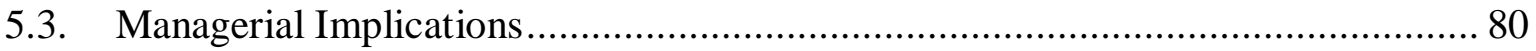

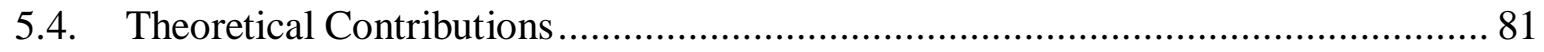

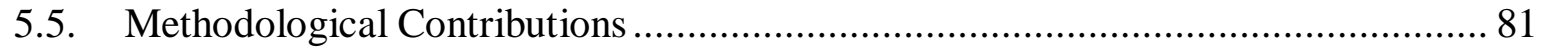

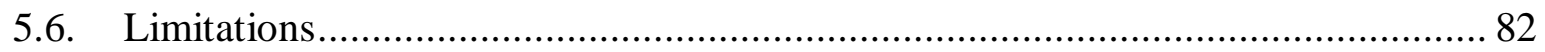

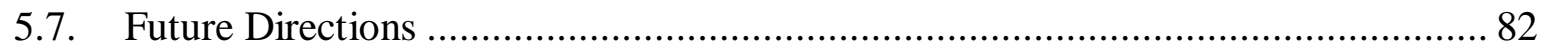

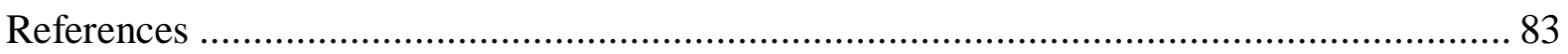

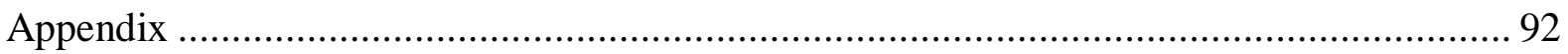

Appendix 1. Participant Information Sheet (English) .......................................... 92

Appendix 2. Participant Information Sheet (Indonesian) ............................................. 94

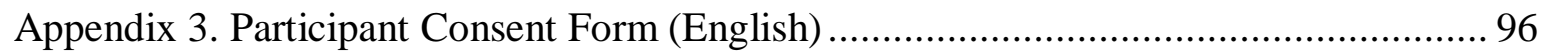

Appendix 4. Participant Consent Form (Indonesian) ............................................. 97

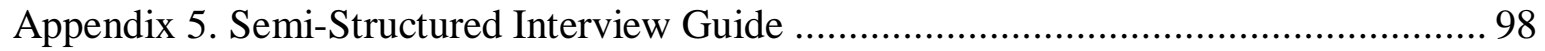

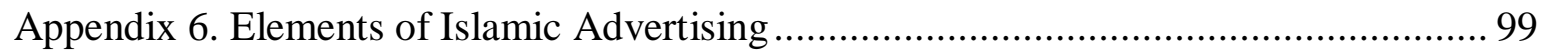




\section{Chapter 1. Introduction}

\subsection{Background}

Religion has been acknowledged to be an important consideration of marketers when creating marketing communications such as promotions and advertising campaigns (Delener, 1994). Consequently, Cader (2015) has noted that there is an increase of research conducted on the relationship between advertising and religion over the past decade. There is an especially growing interest in researching Islam, either in comparison with other religions (A. J. Ali \& Gibbs, 1998; Fam et al., 2004; Farah \& El Samad, 2014; Gibbs \& Ilkan, 2008) or as the focus of the research (Cader, 2015; Haque et al., 2010).

In comparing between the two religions, Gibbs and Ilkan (2008) found that Muslims and Christians have a negative attitude towards "ethically objectionable" promotional images and that religious intensity is a strong indicator of offensiveness. However, Muslims are found to be more sensitive and more offended by these images. Moreover, Fam et al. (2004) also found that religion has an effect on consumers' perception of advertising and that there is a "statistical distinction" between Islam and the other faiths that they studied (Buddhism, Christianity and non-religious beliefs such as Confucianism and Taoism). With these differences between Muslims and people of other faiths, it can be concluded that previous research on the link between advertising and religion has brought into attention the need to study Islamic advertising in particular.

Nevertheless, these previous research used a quantitative approach and thus were not able to discover why these differences exist and what forms the distinct perceptions of Muslims. In addition, Qutb (1997) believes Islam to be a misunderstood religion, thus more research is needed to investigate the Muslim faith, identity and implications for many aspects of life, including advertising. This is important to study as for Muslims, Islam is a "transcendental reality" (Jafari \& Süerdem, 2012) and as "a way of life and lifestyle choice" (Wilson et al., 2013), thus it is accepted as a guidance for all decisions and judgements in life. Limited research on Muslim consumers have been argued to created marginalisation of these more than one billion population of the world (El-Bassiouny, 2014).

Previous research have attempted to study the topic of Islamic advertising or advertising from an Islamic perspective. However, these were dominated by those conducted in Middle 
Eastern countries (Bari \& Abbas, 2011; Hassan et al., 2008; Rice \& Al-Mossawi, 2002; Mohammad Saeed et al., 2001). Research has yet to understand the richness and diversity of Muslims as interpretation of Islam in different parts of the world may vary. Middle Eastern countries such as Saudi Arabia is considered to be more conservative than other regions in the world (Cader, 2015; Rice \& Al-Mossawi, 2002). There is very few research which studied Muslims in other parts of the world in terms of how their interpretation of Islam influences their perceptions on advertising. Furthermore, the majority of articles written on Islamic advertising have been conceptual papers derived from interpretations of the Quran and the Hadith or previous literature which have done so. There is still few research on Islamic advertising from the eyes of Muslim consumers.

Indonesian Muslim consumers have been relatively under researched, even though the country is home to the world's largest Muslim population with 207.2 million people (Statistics Indonesia Population Census 2010). Based on these huge numbers, Hefner (2011) also states that "what Indonesian Muslims think and do should be a matter of general interest". In addition, this provides a grand opportunity for marketers and emphasises the need to understand how their religion affects Indonesian Muslims' perceptions on advertising.

Another aspect that has been under researched is the diversity found within the country. As El-Bassiouny (2014) highlights, future research in marketing need to study how the Islamic theology is perceived, interpreted, and applied in different cultures. Islam in Indonesia is more concentrated on the Western regions of the country, while the Eastern regions contain a higher proportion of adherents of other faiths. There are also ethnic factors which come into play within the country, such as the adoption of Islamic laws in Aceh or the acculturation with Hinduism and Buddhism found in many areas of Java. These ethnic factors distinguish Indonesia from other countries in the world, and thus emphasise the need to study this interaction between religion and culture. In a study by Massey, Waller, Wang, and Lanasier (2013) it was found that the stricter Muslims of West Sumatra have a higher purchase intent compared to Javanese Muslims for an ethical advertisement that was shown, when the advertisement is perceived as likeable. However, ethnicities in Indonesia go beyond these two and future research need to take into considerations how the cultural ethnic diversity may influence consumer perceptions and behaviour, including those related to advertising. 


\subsection{Research Gaps}

There are several gaps that have been identified, which guides the direction of this research.

- First of all, most research on Islamic advertising discuss concepts and guidelines derived from Islamic sources (the Quran and Hadith) and also previous literature reviews (Bari \& Abbas, 2011; Hassan et al., 2008; Rice \& Al-Mossawi, 2002; Mohammad Saeed et al., 2001; Zarrad \& Debabi, 2015). Several research have confirmed these literature with opinions from experts, either academics or Islamic scholars (Nooh, 2009). However, there is little to none that investigated consumer perceptions, even though consumers are the target of these advertisements. Moreover, consumers do not necessarily have the same level of knowledge as experts, which may impact their perceptions of Islamic advertising. Thus, it becomes important to study Islamic advertising from the perception of consumers.

- Secondly, more research needs to be conducted on the influence of culture on Islamic interpretations which play a role in shaping the customers' understanding of Islamic advertising (Naseri \& Tamam, 2012). With the differences in language, culture and location (Sandikçi \& Rice, 2011), it is simply not enough to consider all Muslims as a homogenous segment, especially as Muslims in different countries may adopt different schools of Islamic jurisprudence (Cader, 2015). Further research also needs to be done on the influence of different ethnic cultures which exist in one country (Massey et al., 2013), such as Indonesia, as consumers' identity can be influenced by both local and national cultures. Therefore, in researching Islamic advertising, future research needs to take into consideration the interactions between the consumers' culture and religion (El-Bassiouny, 2016).

- Thirdly, Bailey and Sood (1993) posit that Muslims have a tendency to be more committed to their religion as compared to people of other faiths. Consequently, they predominantly identify themselves as Muslims (Uddin, 2003) before considering national identities. Nevertheless, there is an absence of research which examines the congruency of Islamic advertising with the consumers' identity as Muslims. Furthermore, there is little understanding on how this congruency may have persuasion power in terms of affecting Muslim consumers' attitudes and behaviour. 


\subsection{Research Contributions}

This research provides benefits for marketing researchers and practitioners. For researchers, this study attempts to provide a greater understanding of the consumers' perspectives of advertising. This study also provides insights into Muslims from different ethnic backgrounds, which have been relatively under researched. From this research, practitioners can also benefit by understanding what constitutes Islamic advertising, and how it affects consumer attitudes and behaviour so that more persuasive advertising strategies can be developed.

\subsection{Research Objectives}

This research has the objective of gaining a greater understanding of Indonesian Muslim consumers' perceptions of Islamic advertising, and the congruency with their identity, and effects on attitudes and behaviour. More specifically, this objective is explored through three research questions, which consist of:

1. What does Islamic advertising mean to Indonesian Muslim consumers?

2. How do cultural factors influence Indonesian Muslim consumers' understanding and perceptions of Islamic advertising?

3. Is there any congruency between Islamic advertising and Indonesian Muslim consumers, and how will this congruency/incongruence affect their attitudes and behaviour?

\subsection{Research Methodology}

The paradigm which underlies this thesis is post-positivism with the ontology of critical realism. The research approach is qualitative in which data was collected through semistructured in-depth interviews with 25 participants who are Indonesian Muslims with various characteristics. Thematic analysis were then used to search for patterns within the transcribed interviews. 


\subsection{Thesis Outline}

This thesis consists of five chapters. Chapter 1 has introduced the study, and outlined the objectives and contribution of this research. Chapter 2 provides a review of related literature by drawing from a wide range of disciplines including marketing, sociology, psychology and Islamic studies, as well as the research gaps identified. Chapter 3 describes the philosophical and methodological approaches that were adopted for this research. Chapter 4 presents the findings of this study, along with discussions as informed by the relevant literature. To end, Chapter 5 delivers the study's conclusions, theoretical, methodological and managerial implications, and also research limitations. From these, potential directions for future research were given. 


\section{Chapter 2. Literature Review}

This chapter will identify and discuss the key literature related to the research topic. The approach starts from a broader perspective by discussing articles in the advertising literature, including the standardisation versus localisation debate and persuasion theory. Next, the discussion will proceed to examine identity and multiple facets of the self, including the religious self. This is followed by an examination of previous literature on the link between advertising and religion in general. Subsequently, the discussion will focus on Islamic marketing and Islamic advertising by dissecting it into two aspects, specifically ethical and cultural aspects. An overview of Indonesia as the context of the study is also given. This literature review results in the identification of a gap, which forms the foundation of the research objective in this study.

\subsection{The Standardisation versus Localisation Debate}

The debate about whether to standardise or customise advertising to suit local markets has continued since the seminal publications of Elinder (1965) regarding cross-national advertising in European markets, Fatt (1967) who warns of the danger of over-localisation, and Buzzell (1968) who discusses whether multinational corporations can standardise their operations. Furthermore, Levitt (1983) highlighted the concept of globalisation in his article "The globalization of markets". He observed, "well-managed companies have moved from emphasis on customizing items to offering globally-standardized products that are advanced, functional, reliable and low priced". He believes that was because consumer preferences gradually converge, forming markets with lower costs and prices due to economies of scale. Some have dismissed globalisation as a myth, arguing that "there is no strong empirical evidence that the world is becoming more homogeneous" (Wind, 1986). On the other hand, advocates of globalisation believe that it "leads to global products, global brands and global advertising" (Van Raaij, 1997).

The standardization versus customisation debate is also referred to as the global-local dilemma. In relation to advertising, it refers to the decision as to "whether to standardize advertising for efficiency or to adapt to local habits and consumer motives to be effective" (De Mooij \& Hofstede, 2010). Both views have their own advantages. Standardising 
advertising can aid in keeping a uniform global strategy and image of the company, thus leading to cost advantages, and the ability to meet the universal need of consumers in various countries (Buzzell, 1968; Levitt, 1983; Okazaki, Taylor, \& Zou, 2006; Yip, 1995). Whereas the adaptation approach puts forward that linguistic, cultural, religious, and socio-economic differences can have an impact on how consumers interpret advertising messages, which implies that advertising messages may not be transferrable across countries nor markets (An, 2007; Mueller, 1987; Roth, 1995).

This debate or dilemma has therefore stimulated research on culture in order to understand global advertising (De Mooij \& Hofstede, 2010). Hofstede and Hofstede (2005) define culture as the collective programming of the mind that can be used to distinguish members of a group from other people who are non-members. They propose five cultural dimensions, which include: power distance; collectivism/individualism; masculinity/femininity; uncertainty avoidance; and short/long term orientation. These dimensions have been used numerous times to explain variations in the self, personality, and identity, which are linked to branding, communications and advertising (Cheong, Kim, \& Zheng, 2010; Moon \& Chan, 2005; Polyorat, Alden, \& Alden, 2005).

\subsection{Identity and the Self}

De Mooij and Hofstede (2010) discuss how cultural models can and have been applied to advertising research. They begin by emphasizing that culture is not an external factor, but is embedded within the self. Thus, cultural values define the self and also the personality of consumers. They explain that the self-concept varies between cultures as in a collectivist society; the self cannot be separated from its surrounding social context. That is why advertising in collectivist cultures is more focused on building relationships and trust with the seller, rather than informing and persuading consumers as is the case in individualistic cultures (De Mooij \& Hofstede, 2010; Miracle, 1987).

The term self-concept can be defined as "totality of the individual's thoughts and feelings having reference to himself as an object" (Rosenberg, 1979, p. 7). Researchers have viewed self-concept from many different perspectives. Generally, self-concept has been understood to be multidimensional construct (Burns, 1979; Rosenberg, 1979). In the multiple selfconstructs view, some researchers have viewed self-concept as having two components, namely the actual self and the ideal self, where the latter can be defined as the image that one 
would like to be (Belch, 1978; Belch \& Landon Jr, 1977; Delozier \& Tillman, 1972; Dolich, 1969). Breaking it down further, Sirgy (1980) has described self-concept to consist of four components, namely actual self, ideal self, social self, and ideal social self. The social self (looking-glass self or presenting self) is the image that one believes others hold, while the ideal social self (desired social self) is the image that one would like others to have of the person (Maheshwari, 1974). Similar to this view, Onkvisit and Shaw (1987) describes the components of the self to consist of the real self, self-image (the way one sees themselves), the ideal self (the way one would like to be), and the looking glass self.

In relation to identity, Smaoui and Ghariani (2011) have distinguished between self identity, social identity, and cultural identity. Self identity originates from one's individual personality traits and interpersonal identity (Hannum, 2007). Meanwhile, social identity is part of one's identity due to being a member of a certain group which sets the way of thinking about the self and other people based on social groupings (Hannum, 2007). These groupings can be based on gender, age, ethnicity, race, nationality and socioeconomic status. Cultural identity is one that is based on one's environmental culture, which forms when one submits to the values, standards, and representations of a particular cultural group (Smaoui \& Ghariani, 2011). This identity can also be multicultural for some people as they may integrate several cultures at the same time.

\subsection{Congruity and Persuasion Theory}

Advertising has the goal of persuading or influencing (O'Guinn, Allen, \& Semenik, 2000; Wells, Burnett, \& Moriarty, 1998), or to enforce attitudes (Nan \& Faber, 2004). Persuasion is predominantly a communication process (Schramm, 1973). Meanwhile, advertising is also classified as a form of communication (Richards \& Curran, 2002). That is why there is an abundance of research on the topic of advertising, which examine theories of persuasion and attitude changing.

More specifically, Naseri and Tamam (2012) have noted that Persuasion Theory distinguishes between two main modes of information processing which affect the formation of attitude in different circumstances, namely cognitive (or systematic) and affective (or heuristic) information processing. 
After a review of previous research, Armstrong (2011) has concluded that there are several principles to increase the persuasion of advertising. First, rational and emotional appeals should not be mixed. Second, for advertisements with strong messages, indirect conclusions can be made if consumer resistance is expected. Third is to not ask consumers to evaluate their own satisfaction as it induces a more critical attitude instead of enjoying their experience with the product.

Furthermore, Zhang (2010) has noted that in investigating persuasion, it is important to examine the cultural congruency effect because an advertising appeal which is congruent with one's cultural orientation would induce a stronger preference. In line with the congruity theory (Osgood \& Tannenbaum, 1955), changes in evaluation correspond with increasing congruity with the existing frame of references. Several studies regarding the congruity between one's self and cultural orientations, with advertising appeals in persuasion have found that congruency with one's cultural orientation, as a point of reference, leads to more favourable attitudes (Han \& Shavitt, 1994; Hong \& Zinkhan, 1995).

Nevertheless, in examining the persuasion power of advertisement, marketers must also consider the existence of consumer scepticism toward advertising. This is defined as the negative attitudes that consumers have towards the claims and motives of advertisers (Boush, Friestad, \& Rose, 1994). According to Friestad and Wright's (1994) Persuasion Knowledge Model (PKM), consumers learn about marketers' strategies, tactics, and motives from various sources, and consequently utilise this persuasion knowledge when they are exposed to advertising. As this knowledge may impact the way consumers interpret and respond to advertisements, sceptical consumers may disregard the messages in the advertisement or even develop counter-arguments to them (Nan \& Faber, 2004).

\subsection{Advertising and Religion}

A. J. Ali and Gibbs (1998) have noted that "there are certain religious principles that are taken for granted, yet they influence individuals' behaviour and actions on a daily basis." As Mokhlis (2009) has described, religions affects consumers by influencing one's beliefs, values and behavioural tendencies. Religion also becomes an important consideration of marketers when creating marketing communications such as promotions and advertising campaigns (Delener, 1994). Consequently, Cader (2015) has noted that there is an increase of research conducted on the relationship between advertising and religion over the past decade. 
Religiosity can be defined as an individual or group's level of commitment to a certain religious belief system (Renzetti \& Curran, 1998). Religiosity is an essential value in one's cognitive structure, and can influence one's perceptions (Muhamad, 2009) and behaviour (Delener, 1994). Therefore one who is more religious has a higher tendency to align their behaviour with the belief and practices of their religion (Delener, 1994).

Gibbs and Ilkan (2008) found that Muslims and Christians have a negative attitude towards "ethically objectionable" promotional images and that religious intensity is a strong indicator of offensiveness. In comparing between the two religions, they also found that Muslims are more sensitive and more offended by these images. Farah and El Samad (2014) also found similar results when researching the perceptions of Muslims and Christians on the advertising of offensive products. Moreover, Fam et al. (2004) also found that religion has an effect on consumers" perception of advertising and that there is a "statistical distinction" between Islam and the other faiths that they studied (Buddhism, Christianity and non-religious beliefs such as Confucianism and Taoism). Thus, it can be concluded that previous research on the link between advertising and religion has brought into attention the need to study Islamic advertising in particular. However, these previous pieces of research used quantitative approaches and thus were not able to discover why these differences exist and what forms the distinct perceptions of Muslims. In addition, Qutb (1997) believes Islam is a misunderstood religion, thus more research is needed to investigate the Muslim faith, identity and implications for many aspects of life, including advertising.

\subsection{Muslim Identity}

For those who are adherents of Islam, their first and foremost identity is that they are Muslim before considering any other aspect of life (Uddin, 2003). For Muslims, Islam is a "transcendental reality" (Jafari \& Süerdem, 2012) and "a way of life and lifestyle choice" (Wilson et al., 2013), thus it is accepted as a guidance for all decisions and judgements in life. More recently, the Islamic resurgence has made it evident that Muslims are experiencing a rising religious commitment (Muhamad, 2009). Wilson et al. (2013) have also observed that this resurgence of Islam and Islamic values have developed hand in hand with increasing globalisation, which has resulted in large segments of Muslim consumers who are wanting the 'best of both worlds'. On the one hand, they are keeping their faith in Islamic values that 
they believe in, and on the other hand, they are willing to be involved in global consumer culture (Sandikçi \& Ger, 2011).

Nevertheless, there has been critique regarding the over-generalization of Muslims (ElBassiouny, 2014; Sandıkçı, 2011). As Sandikçi and Rice (2011) have argued, "Muslims are characterized by diversity and dynamism". Moreover, Sandıkçı (2011) has warned that Muslims should not be assumed to be a homogenous segment as this can generate a stereotyped understanding of Muslim consumers. In reality, they are also distinguishable by other factors such as gender, class, age, nationality, and ethnicity. Furthermore, El-Bassiouny (2014) has emphasised the influence of culture in the applications of Islamic teachings, which affects how the Muslim identity is constructed and lived. This is in line with Smaoui and Ghariani's (2011) observation that even though they have the same religion, Muslims from different countries show distinctions in various social, cultural or historical aspects.

Furthermore, with the global cultural flow, Wilson et al. (2013) have noted the "emergence of negotiated multi-layered Muslim identities and lifestyles" which would provide interesting avenues for research. In relation to this, Z. Abdullah (2008, p. 9) also posits that Muslims negotiate their identities as there are situations where they have "multiple belongings or hybrid identities". This causes the multiple identities to converge or overlap, but in other cases one dominant identity may emerge. This emphasises that there is no single boundary between inclusion and exclusion of certain identities. Therefore, a Muslim's religious identity often also meets their socio-cultural identities.

\subsection{Islamic Marketing}

Islamic marketing has been recognised as a distinct discipline (Wilson \& Grant, 2013; Wilson \& Liu, 2011). A. J. Ali and Al-aali (2015) posit that in Islamic thought, marketing is accepted as an important business function that contributes to societal stability and prosperity. Islamic marketing has also been viewed as macromarketing with the ultimate end of achieving hasanah, or good in this life and the Hereafter (Kadirov, 2014). The emergence of Islamic marketing has been seen as the impact of two major forces, namely global capitalism and global Islam (Ger, 2013).

Arguments regarding the importance of Islamic marketing can be categorised into three main points (Wilson et al., 2013). Firstly, the economic argument indicates that there is large 
market potential to tap into the needs and desires of Muslim consumers. This is evident from the numerous Muslim populations in the world and their growing spending power. Second is that beyond profit orientation, there is a consumer-based obligation to adhere to Sharia principles. That is why halal awareness increases as consumers no longer take their consumption for granted. Third is the argument that Islam is influenced by geopolitics, but also has the power to impact upon many international issues, such as international relations and national brand equity. Wilson et al. (2013) also summarised these three points by arguing that Islamic marketing actually goes beyond the Islamic religion, and beyond Muslims to become an additional movement in marketing and management, much like fair trade and total quality management.

In this emerging field in marketing, Sandikçi and Jafari (2013) have identified two research approaches that have been taken by researchers. The first is one that explores Muslims as a distinct consumer segment, which marketers must tailor to, while the second is one that adopts a more critical cultural perspective. In this latter stream, research has explored the relationship between religion and identity, and how consumption plays a role in "constructing, maintaining and communicating Muslim identities" (Sandikçi \& Jafari, 2013, p. 414).

\subsubsection{Islamic Marketing Ethics}

Marketing ethics have been defined as a study of how moral standards are applied to marketing decisions, behaviour and institutions (Murphy, 2010). In contrast, A. J. Ali and Alaali (2015) have pointed out that Islamic ethics differ from this mainstream definition due to its emphasis on behaviour and practices, which serve societal interests, while also heeding corporate goals. A. J. Ali (2011, p. 20) defines Islamic ethics as "specified rules that govern individuals and organisational conduct and seek to ensure generosity, transparency, and accountability in behaviour and actions while safeguarding societal interests". Thus, in linking it with marketing, Islamic ethics promote responsible marketing practices that are in line with Islamic laws and teachings.

Ethics governs all dimensions of a Muslim's life, both the spiritual and the material (Uddin, 2003). However, Islam is expected to strike a balance between the two, as it emphasises human well-being through socio-economic justice (Chapra, 1992). In Islam, the term is commonly used interchangeably with morality (Hanafy \& Sallam, 2001). 
The main purpose of ethics is to provide a systematic and logical reason for what is deemed to be right and virtuous in comparison to what is wrong and bad (Muhamad, 2009). Piety plays a key role in Islamic ethics and is considered an ideal ethical value of Islam (Nanji, 1991). The concept of piety is important in Islam as it encompasses a Muslim's constant consciousness of God's presence and thus teaches obedience to God and avoidance of disobedience (M. Y. Ali, 2016).

There are three general premises of Islamic ethics as described by A. J. Ali and Al-aali (2015). First, conduct that has benefit to the people is also an act that serves God (Qur'an: Oxford World Classic edition, 2005 Surah 49 Verse 13). Second, the value of any act is derived from its accompanying intention. Third, the soundness of moral judgement is seen from the ability to benefit other people in comparison to harm. These premises form a framework of Islamic marketing ethics, which can be further divided into specific marketing functions or practices of the marketing mix, including promotion such as advertising.

\subsection{Islamic Advertising}

Advertising is seen to be an area of Islamic marketing that is receiving an increase in attention (Turnbull, Howe-Walsh, \& Boulanouar, 2016). Furthermore, Haque et al. (2010) suggested that Muslims' judgments are affected by the degree of their religiosity as religious compliance is an essential part of their lives. Thus, to Muslims, advertisements need to have the right appeal and be consistent with their "religious understanding, knowledge and feelings". De Run, Butt, Fam, and Jong (2010) have also postulated that advertisements that do not consider the sensitivities of Islamic values risk losing sales and possibly their corporate image. Even so, there is no generally accepted definition of Islamic advertising. Mokhtar and Samsudin (2015) have interviewed academics of Islamic background with the aim of understanding the concept of Islamic advertising. Based on their findings, Islamic advertising is one that is Sharia-compliant (in accordance with Islamic laws and teachings) and "can be used as a method of dakwah" (informing and calling people to Islam or the truth).

As Kuran (1995) has explained, one of the objectives of Islamic economics is to educate Muslims about the behavioural norms that are sourced from Islamic texts and teachings. He has also observed that the mass media is utilised in many countries to reach this objective. Nevertheless, more research is needed on how Islamic advertising can actually be 
conceptualised and how it links with the congruity of Muslim identity and thus its powers of persuasion. Moreover, Ariffin, Ismail, and Shah (2016) have explained that advertisements that aim to promote Islamic values must encourage customers to perform good deeds. This encouragement is achieved by advertisements representing Islamic behaviour and Islamic principles, the way they are prescribed in the Quran, and also by paying attention to decency in the exposure of advertising messages. The following section will discuss Islamic advertising more specifically from two different aspects, namely the ethical and the cultural aspects.

\subsubsection{Ethical Aspects}

The Islamic law, with its detailed ethical guidelines, can play a role providing appropriate standards in the practice of advertising (Haque et al., 2010). This can be done by deciphering the guidelines provided from Islamic sources such as the Quran and Sunnah (sayings, teachings and the lifestyle of the Prophet Muhammad) into specific screening measures to ensure that advertisements are in line with Islamic law. Previous research has attempted to provide ethical guidelines from an Islamic perspective (Bari \& Abbas, 2011; Hassan et al., 2008; Rice \& Al-Mossawi, 2002; Mohammad Saeed et al., 2001). Mohammad Saeed et al. (2001) believe that these guidelines are not only ideals, but also practicable actions to be implemented. Thus, all marketing activities, including advertising, should be guided by Islamic ethics and in line with the spirit of Islam (Arham, 2010).

Furthermore, ensuring that advertising follows Islamic ethics also encompasses the whole advertising process, not just the advertising messages and strategy (Turnbull et al., 2016). Paying attention to the whole process would start from the strategic planning, research and development, the creative production, up to media planning and buying. Turnbull et al. (2016) links this with the core aspect in Islamic ethics, namely Tawheed (Unity of the Omnipotent God).

Related to the specific advertising messages and appeals, Bari and Abbas (2011) have identified that absence of exaggeration and deception, fairness, restrictions on sexual appeal are important elements to be considered when creating advertisements that are in line with the Islamic ethical system. On a similar note, Munazza Saeed and Baig (2013) have also noted the importance of truthfulness in advertising and selling products. Therefore all information, including that regarding the defects of a product, must be communicated truthfully. Abuznaid 
(2012) has also derived some guidelines for promotional strategies based on the Quran, which include no suggestive language and behaviour, no sexual appeal, no deception, no manipulative promotional behaviour and no misleading advertising. Based on these articles, it can be concluded that honesty in advertisement is a commonly expected aspect of Islamic ethics.

Furthermore, Hanafi and Sallam (1988) have also identified several dimensions of Islamic advertising, including truthfulness, trust, justice, brotherhood, sincerity, and science and knowledge. In her book regarding marketing mix from an Islamic perspective, K. Abdullah (2008) has also discussed ten categories which encompass Islamic values in advertising. These are comprised of morale in advertising, encouraging good deeds (dakwah), truthfulness and no fraud, mutual consent, communication styles, fulfilling promises, sales force management, justice and fairness, moderate spending, and the spirit of sadaqah (charity giving).

Mohammad Saeed et al. (2001) have added that "promotional techniques must not use sexual appeal, emotional appeal, fear appeal, false testimonies and pseudo-research appeal, or contribute to the dullness of the mind and/or encourage extravagance". The authors explained that these techniques are considered unethical in Islam as they exploit the basic instincts of consumers to obtain private gains (profits and market share). The restrictions against encouraging extravagance is in line with the Islamic principle of balance, which emphasises moderation of Muslims in every aspect of life (Y. Ali \& Khan, 2014). On the one hand Islam does not discourage the pursuit of wealth, but extravagance and wastefulness are prohibited. This sentiment is expressed in the Qur'an as "eat and drink, but do not be extravagant verily, Allah does not love extravagant people" (Qur'an: Oxford World Classic edition 2005 Surah 7 Verse 31).

Nevertheless, it should be noted that previous research on Islamic perspectives of advertising are dominated by conceptual papers and few have investigated the views of the consumers in order to confirm these conceptual pieces of research.

Waller and Fam (2000) have researched the views of practitioners in the advertising industry and the regulations in the Malaysian Advertising Code Television and Radio. They noted several restrictions regarding advertising in Malaysia, which are based on Islamic values. Some examples of these restrictions include nudity, indecent language and sexist images. There is an especially rigorous guideline on how women should be portrayed in the media, 
including a dress code on the amount of skin that can be seen in public and good behaviour as accepted by the local society. The role of women is also an important point in Islamic advertising that Rice and Al-Mossawi (2002) have highlighted. Other points that they consider important include honesty of the advertisement, communication style, justice and fairness, consumption behaviour, modesty, care for the environment and appreciation for the diversity of the human race. This ultimate point emphasises Muslim consumers' appreciation of cultural diversity.

\subsubsection{Cultural Aspects}

Rice and Al-Mossawi (2002) have acknowledged that cultural dimensions should be linked to Islamic values when attempting to build a framework for advertising. These cultural dimensions include relationships with people, time orientation, human nature orientation (self-concept), and activity orientation. Naseri and Tamam (2012) posit that religion can influence and actually dominate culture by providing a set of norms which in turn influences one's opinions and lifestyle. Additionally, according to El-Bassiouny (2014, p. 46), "Islamic application is affected by cultural interpretation and hence is culture-specific".

In researching Islam, it must also be noted that there are different schools of interpreting Islamic law, which have different implications of various aspects of life, including business conduct and advertising. The interpretation in Saudi Arabia is considered to be more conservative (Cader, 2015; Rice \& Al-Mossawi, 2002) and follow Hanbali interpretations. Little research has looked at the interpretations and practice of Islamic law outside of the Middle East. Asia is an especially important region as most of the Muslim population live on that continent.

Waller and Fam (2000) have looked at cultural values and advertising in Malaysia. However, they only studied media professionals' perceptions towards various media and advertising restrictions in the country. Thus, the perceptions of the consumers are still under researched. There is also limited research on Indonesia, even though it has the largest Muslim population in the world.

Within their research, Massey et al. (2013) studied Indonesia, specifically four Indonesian ethnic groups (Bali, Batak, Java, and Minang). Research participants from these last two ethnicities Muslim-dominated, even though the Javanese Muslims are more moderate. The 
authors presented an unethical and ethical advertisement, then measured the respondents' views of the ethicality of the advertisement, the likeability, the attitude toward the advertiser, the attitude toward the brand and purchase intent. It was found that for the ethical advertisement, the stricter Minang Muslims have higher purchase intent when the advertisement is perceived as likeable. This research sheds light on different perceptions that Indonesian Muslims may have based on their cultural backgrounds. Recent research has also found that Indonesian Muslims of different ethnicities and different demographic characteristics may have differing evaluations towards advertising (Purnama \& Safira, 2017). Additionally, Abdullah and Ahmad (2010) found that the religious education background and the states that they reside in influence Malaysian Muslims' opinions on Islamic promotional practices. However, no study has been done so far to explore how and why these differences appear.

\subsection{The Context: Indonesia}

Indonesia, the world's largest archipelago nation, is located astride the equator and consist of more than 17,000 islands extending 5,150 kilometres (3,200 miles) east to west, between the Indian and Pacific Oceans in Southeast Asia. Indonesians are separated by seas and clustered on islands.

Most of Indonesians may see themselves first by their ethnic and cultural group and secondly as Indonesians. There are more than 300 ethnic groups in Indonesia. The largest ethnic group in Indonesia is the Javanese who make up about $40 \%$ of the total population. The Javanese are concentrated on the island of Java but millions have migrated to other islands throughout the archipelago since the transmigration programme. The Sundanese, Malay, and Madurese are the next largest groups in the country.

Notwithstanding, Indonesia also has many cultural similarities with other Southeast Asian countries. There are some common characteristic traits, which include common frames of reference in history, culture, and religion, especially countries with the same Malay race as Malaysia and Singapore. The predominantly the Malay race lives mostly in coastal areas and western parts of Indonesia while the eastern parts are mostly inhabited by the Negrito race (Wiryomartono, 2014). 
The cultural diversity in Indonesia has been shaped by long interaction between original indigenous customs and multiple foreign influences. Perfectly located along ancient trading routes between the Far East, South Asia, and the Middle East, resulting in many cultural practices being strongly influenced by a multitude of cultural groups. This fact leads to a complex cultural mixture very different from the original indigenous cultures.

Those cultural mixtures can be seen clearly in Jakarta. As a capital city of Indonesia, Jakarta is not only the seat of the national government and centre of business activities but also a melting pot of various cultures from many parts of the archipelago. Being home to tens of millions of people, the city is where the numerous modern skyscrapers fuse with traditional Betawi's (locals) architecture and the legacies of the country's national history.

This megapolitan city has a high number of migrants from many areas, especially after the Eid al-Fitr. Like many other countries, Indonesia has an annual tradition of travelling to one's hometown during this religious holiday. The population of Jakarta usually increases significantly after this period. Some Indonesians from rural areas come to the city for the Eid al-Fitr festivities, and many them stay in the hope of finding jobs in the capital. This is partly because of the wealth disparity between Indonesian villages and cities. With this influx in population, the city tends to keep growing in diversity, highly outnumbering the local people of Jakarta (Betawinese).

However, in terms of religious affairs, the constitution of the Republic of Indonesia recognises freedom of worship. Currently, six religions are officially recognised by the Ministry of Religious Affairs: Islam, Catholicism, Protestantism, Buddhism, Hinduism, and Confucianism. Other religious groups may register as social organizations, but this status comes with certain restrictions.

Indonesia is the fourth most populous country after China, India, and the USA. The country is also known as the largest Muslim-majority country, Muslims constitute 86 percent of the total population (Seo, 2013). By 2030, this number is projected to reach 238 million, according to research by the Pew Research Center's Forum on Religion \& Public Life (2015). Even though bearing the title as most populous Muslim nation, Indonesia is a secular state because of its diversity. Most of the Muslims in Indonesia are Sunni, but the Shia, Ahmadhiyah, and Sufi are also represented. 


\subsubsection{Islam in Indonesia}

Islam actually has the same principles everywhere. However, the religion has been articulated around the Muslim countries through a dynamic range of distinctive reflections, ranging from moderate to extremely radical. These various local articulations of Islam are believed to be a reflection of the norms and the universal values of Islam.

Muslims in Indonesia read the same Quran, pray five times a day, perform Ramadan fasting and celebrate Eid as Muslims in other countries do. Nevertheless, there are some differences in interpreting the Quran and also on various other matters regarding Islam that derive from several different schools of thought (mazhab).

According to A. Saeed (1999), most of Indonesian Muslims follow the Shafi'i views while other regions may follow different ones. This school of thought is prevalent in Eastern Africa, Southern Arabia, and southeast Asia, including Indonesia. The Shafi'i school is considered to be the easiest school in terms of social and personal rules.

Furthermore, Indonesia has long been recognised as a moderate Muslim country (Wanandi, 2002). Indonesia's religious landscape is unique since the Indonesian Muslims are more tolerant to other religions and beliefs compared to Muslims in other regions, for instance in some Middle Eastern and North Africa (MENA) countries. In the wake of Islamic resurgence and the growing democratic movements in MENA, it is relevant to see Indonesia as a model of Muslim democracy. The country has successfully maintained a stable democratic government, civil liberties, and tremendous economic growth.

Generally, the Muslim community in Indonesia is divided into modernists (who embrace modern learning but adhere to scriptural orthodox theology) and traditionalists (who are generally followers of charismatic religious scholars). Many modernists belong to a Muslim organisation known as Muhammadiyah, while traditionalists belong to Nahdlatul Ulama (Fachruddin, 2006). According to Driessen (2014) both organisations claim astounding membership numbers of 40 million and 30 million, respectively and amount to $30 \%$ of the total population of the country.

All of those Indonesian Muslim group representatives are allied under the Indonesian Ulema Council originally known as Majelis Ulama Indonesia (MUI). This is the forum for the meeting among the ulema (Islamic scholars), leaders and Muslim Intellectuals from all around Indonesia. It is often described as a quasi-state body. Although it receives funds from 
the state budget, in fact, it is not an official government agency and acts independently. MUI was founded by the Indonesian New Order under the Suharto administration in 1975 as a fatwa authority to advise the Muslim community on contemporary issues (Sugiantoro, 2017).

\subsubsection{Advertising in Indonesia}

Advertising plays a major role in today's business realms. Its vital role in disseminating information has transcended over geographical and cultural boundaries. Qadafi and Wahyudi (2014) argue that advertising has become one of dominant influences over Indonesian society. As such, it can indirectly rule and shape society (Tanaka, 1994). Thus, it is no wonder that advertising is considered the most essential marketing tool and has been recognised to be effective in seizing new customers and building brand image.

In Indonesia, the advertising industry has also expanded rapidly over the years. In 2016, the advertising industry records a $16 \%$ increase in revenue, driven by TV advertising and rapid growth in digital advertising revenue (Euromonitor, 2017). Advertisements are pervasive in the Indonesian television's daily programme as it shows up almost every time the people turn the television on (Goddard, 1998). They can softly persuade, convince, or even manipulate society about almost every single thing in this world (Tanaka, 1994). Some studies show the effectiveness of advertisements to influence society through the many ways of advertising a product (Qadafi \& Wahyudi, 2014).

As the media and advertising market becomes more sophisticated, clear regulation will be required. In doing so, the Government of Indonesia established the Indonesian Broadcasting Commission or Komisi Penyiaran Indonesia (KPI). It is an independent regulatory body founded in 2002, based on the Law No.32/2002 on Broadcasting in order to regulate the advertisements in the country.

Indonesia has had a tumultuous relationship with censorship. The basic legal foundation for the censorship in Indonesia is the broad term Anti-Pornography Law No.44/2008, which has widely defined pornography as "any pictures, sketches, illustrations, photographs, writings, sound, sound image, moving animation, cartoons, conversations, gestures, or other forms of message through various forms of communication media and/or performances in public, which contain obscenity or sexual exploitation." 
Concern about the tremendous growth of the advertising market in Indonesia has led to stricter regulations by KPI as a regulatory body, for topics such as porn, tobacco, and alcohol. Despite Indonesia allowing cigarette advertising on television, advertisements cannot show the cigarette packs or scenes that illustrate actual smoking (Lee \& Johnson, 2013). In accordance with the Indonesian Government Law No.19/2003, the cigarette advertisement is defined as an activity to introduce, publish and/or promote the cigarette with or without the return of money to the society with the purpose of influencing consumers to use the cigarette advertised, and in this case, appears in Indonesian society. Furthermore, alcohol companies are forbidden to advertise on mainstream channels such as television and printed media.

\subsubsection{Islamic Advertising in Indonesia}

Hussin, Yusoff, and Yusof (2015) describe advertising as an expression of cultural values by the articulation of religious elements and effecting to the consumer's purchasing behaviour. OgilvyNoor (2010) further explains that we cannot stereotype the perceptions and preferences of Muslim consumers towards various brands and their marketing communications. For example, halal certification, though important to ensure permissibility, is no longer sufficient to persuade the new Muslim consumer that the entity behind the product carries out its business in line with Islamic principles and values.

Despite Indonesia's Muslim culture can be seen as moderate, the country still retains most of Islam's basic principles that every marketer needs to be aware of. Islamic advertising, basically, is different in Muslim countries. In ultra-conservative Saudi Arabia, women often do not appear in advertising. However, when they do, they only show their eyes. In Indonesia, on the other hand, advertising is more playful and exploits female characters. Ishadi (2011) has observed that during the month of Ramadhan, television in Indonesia experiences a huge increase in Islamic themed broadcast programmes, including sermons, talk shows, television series and music. However, apart from this month, there is very little broadcast on television that reflects Islam, even though it is the belief of the majority of Indonesians.

Complaints regarding vulgar content are received by MUI and then forwarded to the KPI. This is because the problem of television broadcasting is the domain of the KPI authority. MUI takes two approaches to people's complaints simultaneously. Firstly, it undertakes advocacy (taushiyyah) with companies and broadcasters or producers of advertising. This 
advocacy aims to maintain a certain standard and consistency of the use of the term 'halal'; not only pursuing the commercial aspect, but also following the religious moral provisions. Secondly, MUI will also take another step, in accordance with the community's complaint, by reporting it to the KPI as an authorized institution in order to correct the impression of the advertisement's content, and to prevent impressions that could damage social morals (MUI, 2015).

Furthermore, advertisements can potentially deceive the public. Some of advertisements have designed various strategies to shape public opinion for the sake of selling products. Green Sands and Bintang Zero were interesting example of the cases (Muslimdaily, 2014). They claimed that their products are free from alcohol, unlike their other alcoholic beverages. In that sense, many people thought that the products were not haram (prohibited by Sharia). Based on the results of investigations conducted by MUI, the products were not eligible to obtain halal certification given the products still contained small amounts of alcohol even though in small amounts.

Currently, there are some movements, which actively raise the issue of non-Islamic advertisements to the public and regulators. They collect public complaints regarding advertisements that did not comply with Islamic teachings, such as drinking with the lefthand (NahiMunkar, 2013). These movements, such as the one organized by NahiMunkar, an online media which was founded by an ex-reporter, serve as an additional force in filtering advertisements that are considered un-Islamic. Furthermore, to improve the morality of the people, some Muslim leaders plan to release a specific Islamic television channel that contains educational programmes (Permana, 2016).

\subsection{Research Gap}

Based on the literature reviewed above, there are several gaps that have been identified.

- First of all, most research on Islamic advertising discuss concepts and guidelines derived from Islamic sources (the Quran and Hadith) and also previous literature reviews (Bari \& Abbas, 2011; Hassan et al., 2008; Rice \& Al-Mossawi, 2002; Mohammad Saeed et al., 2001; Zarrad \& Debabi, 2015). Several research have confirmed these literature with opinions from experts, either academics or Islamic scholars (Nooh, 2009). However, there is little to none that investigated consumer 
perceptions, even though consumers are the target of these advertisements. Moreover, consumers do not necessarily have the same level of knowledge as experts, which may impact their perceptions of Islamic advertising. Thus, it becomes important to study Islamic advertising from the perception of consumers.

- Secondly, more research needs to be conducted on the influence of culture on Islamic interpretations which play a role in shaping the customers' understanding of Islamic advertising (Naseri \& Tamam, 2012). With the differences in language, culture and location (Sandikçi \& Rice, 2011), it is simply not enough to consider all Muslims as a homogenous segment, especially as Muslims in different countries may adopt different schools of Islamic jurisprudence (Cader, 2015). Further research also needs to be done on the influence of different ethnic cultures which exist in one country (Massey et al., 2013), such as Indonesia, as consumers' identity can be influenced by both local and national cultures. Therefore, in researching Islamic advertising, future research needs to take into consideration the interactions between the consumers' culture and religion (El-Bassiouny, 2016).

- Thirdly, Bailey and Sood (1993) posit that Muslims have a tendency to be more committed to their religion as compared to people of other faiths. Consequently, they predominantly identify themselves as Muslims (Uddin, 2003) before considering national identities. Nevertheless, there is an absence of research which examines the congruency of Islamic advertising with the consumers' identity as Muslims. Furthermore, there is little understanding on how this congruency may have persuasion power in terms of affecting Muslim consumers' attitudes and behaviour.

Therefore, this research will attempt to bridge the gaps by investigating the perceptions of Indonesian Muslim consumers on Islamic advertising. From drawing on the various streams of literature, the proposition in this research is that consumers with higher religiosity will be more attracted to advertisements which portray their ideal self (to be a more pious Muslim), thus the advertisement in general becomes more attractive and is able to induce positive attitudes. 


\section{Chapter 3. Methodology}

In this chapter, the problem identified will be explained based on the literature review in the previous chapter. Consequently, a research objective will be presented, along with three research questions to be investigated. Based on these research questions, the research paradigm will be explained, with an outline of the methodology and methods used.

\subsection{Problem Identification}

Based on the literature review, there is a gap that has been identified regarding the limited research done on Islamic advertising from the perspective of consumers. Moreover, there is also a gap in researching this topic in a context outside of the Middle East. Indonesia has been identified as an important market due to its large Muslim population. How Islam is embedded in Indonesia is also different from Middle Eastern countries as it is considered more moderate. Furthermore, there is also the potential interaction between Islam and the local culture in Indonesia, which may influence the perceptions of Indonesian Muslims in how their religion is lived in daily situations, such as when viewing advertising. This research will attempt to fill this gap by digging further into the perceptions of Indonesian Muslim consumers regarding Islamic advertising. Analysis will also be conducted with consideration of the likelihood as to whether different perceptions exist between Muslim Indonesians with different demographic characteristics, such as different age, gender, and local ethnic backgrounds.

\subsection{Research Objective}

As explained in the problem identification above, this research will attempt to fill the gap that has been identified from the literature review in the previous chapter. More specifically, this research has the following objective:

to gain a greater understanding of the perceptions of Islamic advertising to Indonesian Muslim consumers, and congruency with their identity, and effects on attitudes and behaviour. 


\section{3. $\quad$ Research Questions}

Indonesian Muslims have rarely been the focus of research related to advertising. Waller and Fam (2000) have conducted research to derive the views of the media and advertising industry on the link between cultural values and advertising in Malaysia, one of Indonesia's neighbouring countries. They noted that the Malaysian government's efforts to promote Islamic values have influenced the country's Advertising Code for Television and Radio. Thus, strict rules have been placed on the content that can be portrayed. This research has provided valuable insight into the industry in a Muslim-dominated country, especially one in Asia. However, the findings from Malaysia do not necessarily apply to Indonesia. Mathras et al. (2015) also recommend research on religion to be restricted to participants from the same national culture so that the religious factors can be isolated from the cultural factors. That is why this research aims to specifically study Indonesian Muslims. Furthermore, the views of the consumers have not been captured even though they are the ones being targeted by the advertisements and are the most crucial group to research.

Therefore, the first research question to be addressed is:

RQ1: What does Islamic advertising mean to Indonesian Muslim consumers?

Muslims derive their ethical system, approaches and principles from the Quran and Sunnah (Haque et al., 2010). This would imply that much of what Muslims deem as ethical is based on their understanding of Islamic teachings. Nevertheless, El-Bassiouny (2014) has emphasized the influence of culture in the applications of Islamic teachings. Thus, much of the Muslims' understanding and practice of the religion are influenced by their local culture and the society they identify with. Research has yet to explore the interplay between Islamic religion and local culture in forming the consumers' understanding and perceptions of advertising.

The second research question is:

RQ2: How do cultural factors influence Indonesian Muslim consumers' understanding and perceptions of Islamic advertising? 
Sandikci and Jafari (2013) noted that one popular stream of research on Muslim consumers stems from a "critical cultural perspective", which includes studying the connection between religion and identity, and how consumption can play a role in the construction, maintenance, and communication of Muslim identities. Zhang (2010) observed that recent studies have begun examining advertising appeals in relation to its congruency with one's self and cultural orientation. It is observed that when a certain advertising appeal is congruent with one's cultural orientation, stronger preference and more favourable attitudes will be created. However, limited study has been conducted on congruency with one's religious identity and how it affects attitudes towards certain advertising. There is also limited study on observing the advertisement holistically, instead of just focusing on certain advertising appeals.

The third research question to be investigated is:

RQ3: Is there any congruency between Islamic advertising and Indonesian Muslim consumers, and how will this congruency/incongruence affect their attitudes and behaviour?

\subsection{Research Paradigm}

A paradigm is essential to many fields of research as it set forward what to study, why to study, and also how to study it (Kuhn, 1962). Furthermore, Guba and Lincoln (2004) explain that a paradigm can be considered a set of basic beliefs that deal with core principles. It is a worldview which defines "the nature of the world, the individual's place in it, and the range of possible relationships to that world" (Guba \& Lincoln, 2004, p. 21). Della Porta and Keating (2008) point out that researchers must be aware of the different paradigms or approaches, what differences they have, and how far they can be combined. The different approaches are usually contrasted based on their ontology (disputes about the existence of a real, objective world), epistemology (possibilities of gaining knowledge of the world) and methodology (technical instruments used to gain that knowledge) (Corbetta, 2003).

According to Creswell (1994), disputes of the different approaches are usually represented by two main views, usually positivistic versus humanist. Della Porta and Keating (2008) extend this dualism by identifying four main approaches, namely positivist, post-positivist, interpretivist, and humanistic. In another perspective, Guba and Lincoln (2004) categorised the different paradigms into positivism, post-positivism, critical theory, and constructivism. 
This research is conducted within the paradigm of post-positivism. Positivism is known as the traditional approach which accepts that the world exists independently of the observer (Della Porta \& Keating, 2008). However, post-positivism is a more recent effort over the past several decades to address the main criticisms of positivism (Guba \& Lincoln, 2004). Specifically, post-positivism still believes in an objective reality, but knowledge of it will never be perfect as this knowledge is socially conditioned and may undergo reinterpretation and even challenges (Della Porta \& Keating, 2008). According to Creswell (2013), in practice, research is seen as: a series of logical steps; belief in multiple perspectives from the participants rather than a single reality; and rigorous methods of qualitative data collection and analysis.

\subsubsection{Ontology}

Ontology questions the nature of reality and what knowledge can be gained from it (Guba \& Lincoln, 2004). A paradigm of post-positivism would translate into an ontology of critical realism. This term originates from the requirement that claims about reality must be critically examined in order to understand reality as closely as possible, although never perfect (Cook \& Campbell, 1979). Critical realism has been described as the third way between the naïve realism of positivism, and radical constructionism (Fairclough, 2009). In other words, critical realism "avoids the pitfalls of positivism on one side and idealism and relativism on the other" (Sayer, 2004, p. 15).

In critical realism, reality is believed to exist, but only imperfectly understood due to the limitations of human intellectuals and the intractable nature of phenomena (Guba \& Lincoln, 2004). Therefore, the concept of reality extends beyond the self or consciousness, but is not completely discoverable (Krauss, 2005). Knowledge about this reality, and the meanings it obtains, is said to be socially constructed and therefore affected by history (Belfrage \& Hauf, 2016). This perspective is especially relevant to this research as it has been linked to the belief system in Islam which accepts that there is possible existence of "unseen immaterial realms" (Wilkinson, 2013), which cannot be directly seen, but the effects of it can be experienced.

Zachariadis, Scott, and Barrett (2013) explain that the ontology of critical realism can be seen as a stratification of the real, the actual, and the empirical. The real includes objects and structures with causal powers, which result in mechanisms. Although these mechanisms may 
not be visible, their potentialities may still exist (Bhaskar, 1978, 1998). Secondly, the actual includes events that are generated from mechanisms, both exercised and unexercised. Whereas the empirical is defined as the phenomena, events that can be observed and experienced. Thus, Volkoff, Strong, and Elmes (2007) assert that the main objective in critical realism informed research is to use the observed empirical events to identify the mechanisms that drive those events.

\subsubsection{Epistemology}

Della Porta and Keating (2008) define epistemology as how we can know things. They emphasise that knowledge is different from belief, in the sense that reasons must be given to support a certain statement, which can then potentially convince other people of this knowledge. Epistemology is also described as the relationship between the enquirer and what can be known (Guba \& Lincoln, 2004). For this research, it is assumed that reality can be approximated, though never fully known, which Guba and Lincoln (2004) term objectivist or modified dualist. Furthermore, they explain that essential to this is the role of critical traditions, such as whether the findings fit with pre-existing knowledge, which serve as guardians of objectivity.

In Islamic Critical Realism, as elaborated by Wilkinson (2013), there is a distinction between ontological realism and what he terms epistemological relativism. For Muslims, the Quran is seen as a form of ontological realism, but the act of reading and interpreting it can be considered part of epistemological relativism, which emphasises the potential for human fallibility in judgements and decisions. Epistemological relativism also accepts that human decisions are context specific and historically conditioned (Wilkinson, 2013), including those that are related to religion.

\subsection{Methodology}

Methodology concerns what the enquirer can do to reveal the knowledge they believe can be obtained (Guba \& Lincoln, 2004). In further, Crotty (1998, p. 3) has described methodology as the "strategy, plan of action, process or design lying behind the choice and use of particular methods". Within critical realism, the methodologies of qualitative and quantitative are both possible in order to discover the underlying mechanisms that affect actions and 
events (Healy \& Perry, 2000). Therefore the decision lies on the appropriateness of the research topic and how much pre-existing knowledge is available (Krauss, 2005). As there is still limited knowledge on the concept of Islamic advertising, qualitative methodology was the methodology chosen for this research. Additionally, Zachariadis et al. (2013) posit that the role of qualitative methods is more profound within critical realism as it has higher capability in describing phenomena, constructing propositions or hypothesising, and identifying structures of complex mechanisms (Layder, 1990; Sayer, 2000; Volkoff et al., 2007).

Qualitative research seeks to understand phenomena by investigating meanings that people attribute to their behaviour and the world around them (Della Porta \& Keating, 2008). Thus, the emphasis is more on human nature, including how there are diverse societies and cultures, which may influence or shape these meanings.

\subsection{Methods}

Data was collected through semi-structured in-depth interviews. This approach was chosen due to the exploratory nature of this research. In-depth interviews also enable deeper insights into the perceptions of individual participants and dig into the underlying reasons for these perceptions to be developed. As Rubin and Rubin (1995, p. 75) describe, in-depth interviews focus on "depth, detail, vividness, and nuance". These interviews also limit bias which results from peer pressure, thus participants can freely express their own opinions on the subject of the research.

This research included 25 participants after there was found to be some saturation on the topics that are brought up by the participants. Guest, Bunce, and Johnson (2006) found that saturation occurred after 12 interviews for the purposes of their research. Nevertheless, this research placed greater emphasis on the variety of participants' characteristics, thus more participants were needed. Each interview took approximately 1 hour, but varied slightly among participants.

Before starting the interview, the interviewer explained the research and what questions to expect, without revealing the specific research objective. This was to ensure that there were no biases when conducting the interview. Afterward the initial explanation consent was asked for to conduct and record each interview. Voice recording was important to ensure that there 
was no information missed during the interview and to allow the interviewer to concentrate on the discussions. The participants were also asked to sign a consent form.

The interviews were conducted in accordance with a guideline that was prepared beforehand (see Appendix 5). The opening questions were more general and intended to 'break the ice'. The key question about Islamic advertising will only be introduced when the discussion about advertisements in general became saturated. Throughout the interview, probing was done whenever necessary. This was to ascertain the intended meaning of an answer, ask for examples which would better explain the answers, or check for consistency throughout the interview. It was also necessary to rephrase several questions if the interviewee did not understand the key words that are being asked.

\subsubsection{Participants}

The participants in this research are Indonesian Muslim consumers above 18 years old. This is to ensure that the consumers are already of age to make their own purchasing decisions with their own financial resources. In recruiting the interview participants, purposeful sampling will be used, ensuring that the participants fulfil certain criteria of being Indonesian Muslim consumers. The sampling also aimed to have maximum variation in terms of gender, and ethnicity. Maximum variation sampling is commonly used due to its ability to increase the possibility of gaining research findings which reflect different perspectives (Creswell, 2013). This variation is essential to capture the diverse nature of the Indonesian Muslim consumers. Thus, an analysis can also be done on whether differences in perceptions exist between Indonesian Muslim consumers with different characteristics.

Participants were recruited through personal connections. Each participant was contacted beforehand to ask whether they wanted to participate in the research. The interviews were conducted in a public place of the participant's choosing. After the interview, the participants were also asked to recommend other potential people to be interviewed. This enabled snowballing, especially for consumers with certain characteristics such as ethnicity.

Due to several limitations, all recruited participants were living in Jakarta, the capital city of Indonesia. Jakarta has become a melting pot of all ethnicities, as there is great number of migration from many parts of Indonesia. Thus, it is not difficult to search for a variety of ethnicities in the capital city. It must be noted, that the perceptions of these participants may 
have changed due to being exposed to other cultures. However, this acculturation is seen to better reflect the characteristics of the Indonesian people nowadays as each local ethnicity is no longer secluded from people of other regions.

\subsection{Data Analysis}

Each recoded interview was transcribed verbatim. To analyse the data, thematic analysis was conducted. The transcript was systematically analysed for patterns within the text (Dittmar \& Drury, 2000). Here, the analysis aimed to investigate the participants' "feelings, perceptions and understandings of themselves and social relations" (Dittmar \& Drury, 2000, p. 119). Qualitative data analysis is seen as a way to generate different types and levels of meaning in different aspects of life, even those that seem mundane (Krauss, 2005). Meaning has been categorised into rules and meaning and articulated meanings (Lofland \& Lofland, 2006). Rules are often accepted as shared meanings, such as norms, which usually contain a positive moral tendency. Meaning is communicated from the values behind these rules. On the other hand, unarticulated meanings are those that are not recognised by the participants, instead the researcher identifies them by categorising data through typification. This is done by the researcher attributing meaning to the wide range of data obtained, and then creating generalisations based on those meanings (Krauss, 2005).

First, initial coding was done to break down the data and identify codes in each interview. Subsequently, patterns began to emerge and similar codes were grouped together under certain labels. This labelling was the beginning of theme identification. Themes were also defined to provide more meaning for each label. As a final stage, the themes were examined multiple times and refined to ensure that the correct themes had been chosen to represent the data.

This analysis process was aided by the use of Nvivo software. There are several advantages to computer assistance (Creswell, 2013). These include better organisation of files, aiding the researcher in locating materials, and encouraging the researcher to look more closely at the data in order to conduct more prudent analysis. 


\subsection{Checks}

As a way for ensuring the quality of the analysis, several checks were conducted. Design checks were done to ensure descriptive validity. This was done by making sure that the interviews were transcribed correctly without losing any of the interviewee's intended meaning (Wolcott, 1990). Triangulation was also done by confirming and contrasting the findings in the research with previous literature. Checks were also done to confirm the advertisements that the interviewee mentioned during the interview by searching for them and watching them again. Creswell (2013) describes that triangulation typically involves validating evidence from multiple sources to shed light on a certain perspective or theme. Transferability was also ensured by documenting the methods and processes taken during the research in order for it to be easily replicated in the future.

\subsection{Ethical Considerations}

This research was conducted with approval from the Victoria University Human Ethics Committee. The participants were asked in advance for their willingness to participate in the study. The participants were also given the opportunity to choose the time and place most convenient for them so they would not be pressured. On the day of the interview, consent was asked for once more. Each participant was given an information sheet to read, and all conditions of the research were explained. After the participant agreed to take part in the research, a consent form was signed. Among the points covered in the consent form are the assurance of the confidentiality of the information provided and the anonymity of the participants. None of the information provided can be traced back to each specific participant. The interviews were conducted in a public place and therefore provided safety for both the interviewer and the interviewee. The participants were not forced to answer any questions that were not comfortable for them. They were able to withdraw from the research at any point, and also had the opportunity to opt out of the research within one week of the interview in case they had changed their mind and did not want their information to be included. 


\section{Chapter 4. Findings and Discussions}

\subsection{Participant Details}

The participants for this study were selected to gain a wide range of perceptions from Indonesian Muslims of different backgrounds. In searching for diversity, several categories were used, including gender, age range, local ethnicity and religiosity. There was an almost equal distribution in terms of gender and religiosity, however there were not equal members for the age range and local ethnicity. Most of the participants were younger, ranging from 18 to 44 years old, while only 3 participants were 45 years old and above. For local ethnicity, most of the participants were Javanese, which also reflected the domination of Javanese people among the Indonesian population.

Table 1. Participant Details

\begin{tabular}{|c|l|l|l|l|l|l|}
\hline No. & Name & Age Range & Gender & Religiosity & Local Ethnicity & Interview Duration \\
\hline 1. & Ani & $25-34$ & Female & Moderate & Javanese & $0: 48: 06$ \\
\hline 2. & Caca & $18-24$ & Female & Moderate & Sundanese & $0: 55: 50$ \\
\hline 3. & Doni & $25-34$ & Male & Moderate & Malay & $0: 38: 19$ \\
\hline 4. & Edi & $18-24$ & Male & Moderate & Minangnese & $0: 47: 14$ \\
\hline 5. & Farah & $25-34$ & Female & Religious & Javanese & $0: 30: 32$ \\
\hline 6. & Gilang & $25-34$ & Male & Religious & Minangnese & $0: 36: 12$ \\
\hline 7. & Hadi & $18-24$ & Male & Moderate & Javanese & $0: 40: 37$ \\
\hline 8. & Indri & $25-34$ & Female & Religious & Arab-Indonesian & $1: 02: 40$ \\
\hline 9. & Kemala & $25-34$ & Female & Moderate & Betawinese & $0: 26: 19$ \\
\hline 10. & Khalid & $25-34$ & Male & Moderate & Betawinese & $0: 20: 44$ \\
\hline 11. & Mulya & $18-24$ & Male & Moderate & Javanese & $0: 17: 46$ \\
\hline 12. & Mira & $25-34$ & Female & Religious & Javanese & $0: 39: 14$ \\
\hline 13. & Putri & $18-24$ & Female & Religious & Acehnese & $1: 16: 58$ \\
\hline 14. & Ranti & $35-44$ & Female & Moderate & Minangnese & $0: 29: 09$ \\
\hline 15. & Rizal & $35-44$ & Male & Moderate & Betawinese & $0: 31: 22$ \\
\hline 16. & Roy & $55-64$ & Male & Moderate & Betawinese & $0: 12: 46$ \\
\hline 17. & Sari & $35-44$ & Female & Religious & Javanese & $0: 43: 12$ \\
\hline 18. & Sigit & $45-54$ & Male & Religious & Minangnese & $0: 30: 41$ \\
\hline 19. & Tegar & $25-34$ & Male & Moderate & Javanese & $1: 21: 53$ \\
\hline 20. & Tiara & $55-64$ & Female & Religious & Malay & $0: 23: 35$ \\
\hline 21. & Umar & $18-24$ & Male & Moderate & Javanese & $0: 43: 14$ \\
\hline 22. & Vivi & $35-44$ & Female & Religious & Sundanese & $0: 43: 17$ \\
\hline 23. & Yuda & $25-34$ & Male & Moderate & Bataknese & $0: 23: 06$ \\
\hline 24. & Yasmin & $35-44$ & Female & Religious & Javanese & $1: 54: 52$ \\
\hline 25. & Zahra & $35-44$ & Female & Religious & Javanese & $0: 45: 04$ \\
\hline
\end{tabular}




\subsection{Conceptualising Islamic Advertising}

Islamic Advertising is not a familiar concept, in the academic literature nor among consumers. However, consumers are able to explain their understanding of the concept, which can be derived from the words they use to explain it. Generally, the consumers accept that Islamic advertisements would also be categorised as good advertisements. These contain desirable content and appeal to Indonesian Muslim consumers. From the analysis of interview transcripts, five general themes emerged to conceptualise Islamic Advertising in the eyes of Indonesian Muslim consumers. These themes include compliance with Islamic law (Sharia), Islamic values, execution strategies, products and brands, as well as public figures. A summary of these themes, main discussions under each theme and examples can be seen in Figure 1.

\subsubsection{Compliance with Sharia}

The first theme is the one with the most basic connection to the Islamic faith. Indonesian Muslims believe that Islamic advertisements are those that comply with Sharia and do not go against it. This is a common theme found with several of the participants. The Arabic word Sharia refers to the laws and way of life prescribed by Allah for his servants. Nestorović (2016) elaborates that Sharia encompasses issues related to Islamic ideology, faith, behaviour and manners, as well as practical daily matters, including day-to-day activities and worship rituals. Umar also emphasises that an advertisement must comply with Sharia so that it can be accepted by the Indonesian people.

"If I assess ... Ones that comply with the Sharia." (Khalid)

“...surely, acceptable advertisements in Indonesia should not violate

Islamic rules. It is because if the advertisement has any tendency to violate

Islamic rules, then it would be difficult for people to accept it." (Umar) 


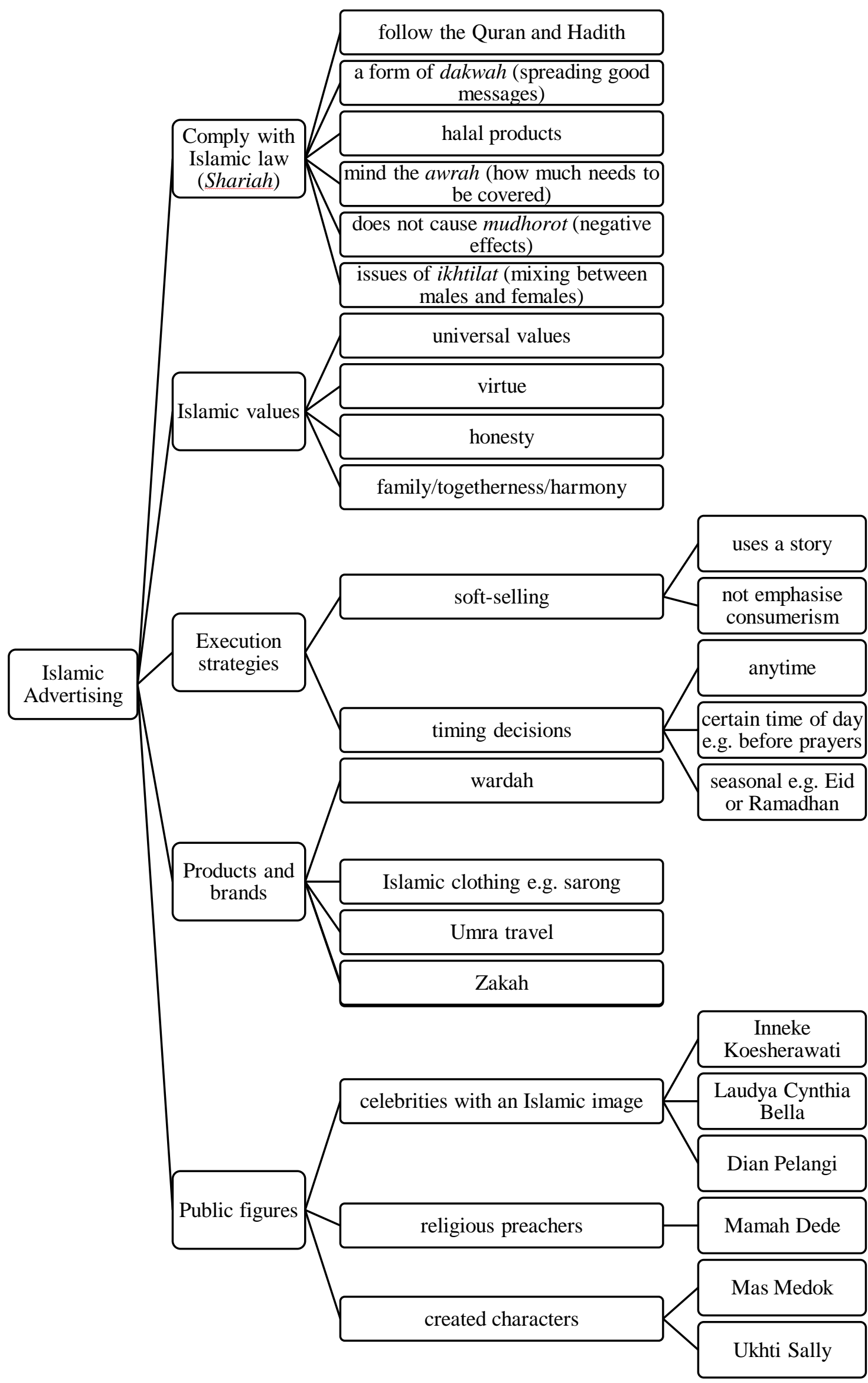

Figure 1. Conceptualisation of Islamic advertising 


\subsubsection{Following the Quran and Hadith}

Compliance with Sharia law would imply that advertisements must follow the Quran and hadith as the main sources of Sharia. Muslims believe the Quran to be the word of Allah (God), thus contradicting the Quran can be compared to going against the word of Allah and consequently Allah Himself. Meanwhile, hadith (or collectively known as Sunnah) is the words, actions and deeds of the Prophet Muhammad, which serves as confirmation and further explanation of the laws, concepts and practical matters that are mentioned in the Quran (Nestorović, 2016). These two sources of Sharia are widely accepted by Muslims, although more specific implementations may vary. This is because there are further sources, which are derivatives of the Quran and hadith, stemming from human interpretation and knowledge. These include ijma (consensus of Islamic clerics on a specific issue or ruling), qiyas (analogy with previously accepted rulings) and ijtihad (personal effort of Muslims to seek the best interpretation that suits society). As Putri emphasises, for Muslims, the Quran and hadith are accepted to be the ultimate truth, whereas human-made laws such as by the government may go astray from Sharia, even in a country such as Indonesia in which the majority of the people are Muslims.

"It is the advertisement that contains Islamic values. Something Islamic has two bases, two guides: The Quran and Sunnah so it is Islamic if its values follow these two." (Sari)

"Because according to me, the norms are based on the Quran and hadith, not based on the government rules because we know that the government is wrong as they try to legalize porn, which is not a correct thing according to the religion." (Putri)

\subsubsection{Awrah and Discussions of Hijab}

More specific discussions on the application of Sharia within advertising are related to the concept of awrah. As elaborated by Badr (2004), awrah is part of the body which must be covered and not be seen by someone of the opposite sex who is not a mahram (spouse or any blood relatives with whom one may not marry, including father, mother, brother, sister, son, daughter, uncle, and aunts). For men, awrah ranges from the navel to the knee, whereas for women, a majority of scholars agree that all parts of the body must be covered except the 
hands and face. Thus, in addition to long and loose-fitting clothes, Muslim women would wear a headscarf commonly known as hijab.

"Essentially, Islamic advertisement does not need to show any Islamic attributes, the point is it could not conflict with Islamic Sharia. For example, the clothes, women must be covered, I mean especially the vital areas. Let us say that if a woman wears a bikini then it clearly is not Islamic, it does not show Islamic wisdom. Forbidden areas are, for example, thighs are supposed to be covered, while in the advertisement, they reveal them, it is then not Islamic." (Tegar)

"Probably Islamic advertising is something that uses advertisement as a media with a content that is in accordance with Sharia. Then if we go back to the question about what should we have in an advertisement, clearly it must not be something that is prohibited in Islam, from the modesty, clothes, and actors' behaviour." (Zahra)

Interestingly, the word that was most often used to described Islamic advertising is hijab (as can be seen in Appendix 1). Evidently, hijab is one of the most common symbols of Islam and one that is recognised by Muslims and non-Muslims alike. Nevertheless, Indonesian Muslims have differing opinions on the importance or even need to use hijab in Islamic advertisements. This is also present in their discussions of wearing or not wearing the hijab, and thus extends to discussions regarding predominantly Muslim clothing as accepted in Indonesian society.

"Islamic advertisement from my point of view, the woman casts must be wearing hijab. As there are a lot of advertisements showing women with revealing clothes, we do not feel comfortable, if (judging from a) very Islamic (point of view).” (Mulya)

"Also the regular advertisements if they want to mention Islam directly...it is also compulsory to wear hijab. I perceive that it is a must for the woman to wear hijab." (Indri) 
"At least there is one person who wears hijab in the advertisement. It is so clear to see." (Hadi)

"Yeah the important one is the main. Probably the one who did not wear hijab is the friend or trying the products. But surely that remains, what is it, so the appeal must be the main actress who is wearing hijab." (Caca)

Although some consumers perceive that Islamic advertisements must contain women stars wearing hijab, they also state that not all the characters in the advertisement need to be wearing hijab. At least one hijabi (a person who wears the hijab) would be enough, but it would become clearer if the one wearing the hijab is actually the main character in the advertisement. This would show that the advertisement puts forward the Islamic appeal of the advertisement.

"Possible if she wears hijab. If she does not wear hijab then it is also fine as long as the appearance is decent." (Vivi)

“..in that one the wife did not wear hijab. Well it is better to wear it if we want to see whether it is Islamic or not. But in that one. Not really, the thingy [woman] didn't." (Mira)

However, wearing the hijab is not the only or even the main criteria when considering whether an advertisement is Islamic or not. The consumers accept that the hijab is one of the clear signs of an Islamic advertisement, but are also willing to accept if the advertisement stars do not wear hijab as long as they are wearing "decent" clothes. Decency and appropriateness of clothing also coloured many discussions throughout the interviews.

Additionally, some Indonesian Muslims were also accepting if the women in the advertisement were not wearing hijab, as long as their clothes were still considered polite and modest. Thus, Indonesians do not impose that people, especially women, must cover all of their awrah as they accept that not all Muslims that they meet in their daily life wear hijab. The clothing requirements were more moderate as modesty can be interpreted differently by different people. Different consumers have different limits to what they consider decent, however, it can generally be described as how Indonesians typically dress. Either long or 
short sleeved tops, with pants or skirts below the knee. Some of the younger participants also accepted shorts or skirts that are above the knee, but not too high that would expose the thigh area too much.

"It is just okay, I mean, there are Muslim women who do not wear hijab, so yeah it is fine. As long as they do not dress too open, if it is Islamic advertisement but there is someone with revealing clothes then it does not match. Revealing the awrah too much, like the chest part. In Indonesia, only the head, right? The hair is [okay to be] shown, I guess. The clothes are still covered. Not really [long-sleeved], maybe long skirt, that is it." (Gilang)

Indonesian Muslims realise that they live in a diverse society, in which not everyone is Muslim. For example, Indri points out that it is also forbidden in Islam to force someone against their will. Thus, she believes it would also go against Islamic teachings if all of the stars of the advertisement were forced to cover their awrah and wear the hijab. Furthermore, not all Muslims practice the faith in the same way. That is why Indonesian consumers do not mind seeing people showing the awrah in advertisements, as it is what they commonly see in their daily lives.

"Well, Unilever is multinational so it is not necessary for everyone to be covered, but they try to show something polite. What I see so far is that they wear polite clothes. It does not need to be the hijab, using cadar and covered until their feet." (Tegar)

"If for example we want to see from the perspective of religion, for an Islamic country then it is not allowed [to show the hair]. But Indonesia is not an Islamic state, why would other religions be forced to wear hijab just to become celebrities? That would mean forcing the will. That is also forbidden by the religion." (Indri) 


\subsubsection{3. $\quad$ A Form of Dakwah}

For Indonesian Muslims, Islamic advertising can also be seen as a form of dakwah (spreading good messages). This is when the advertisements are able to deliver some kind of moral message or values that are promoted in Islamic teachings. Thus, Indri highlight the potential of advertisements to value dakwah, which in Islam is also a form of worship and an obligation for every Muslim.

"for advertisement, it is about how the ad producers create something short but memorable for the people. That is why, bad message would be dangerous but if it is good, then it could be helpful, I mean that could have the value of dakwah [spreading good messages]." (Indri)

The word dakwah was only explicitly used by one participant, Indri was one of the more religious people interviewed. However, a similar theme was also conveyed by other participants through using the word 'educating'. As Tiara describes, religion is a central aspect of life and that everything is based upon faith. Thus, even advertisements can have educational value, for example regarding desirable behaviour for society. Here, religion is emphasised as a moral compass that enables people to distinguish between right and wrong, between good and evil. Thus, she sees Islamic advertisements as those that educate society in how to be good, as prescribed within Islamic teachings.

"Ones which educate kids about how to behave towards their parents, respect their teachers, neighbours, friends, anything educating basically. Religion must be present, regardless of the religion. If we are Muslim then follow Islam, but still in an educational way. Everything has faith as the basis, right? It is not good to omit religion, no faith at all, empty just like that. Meanwhile they are incapable of differentiating wrong or right." (Tiara)

\subsubsection{Halal and the Halal Logo}

An understanding and acceptance of halal (permissible according to Islamic teachings) is considered to be essential to every Muslim (Wilson, 2014). The opposite of halal is haram. 
Deciding whether a substance is halal or haram "depends on its nature, how it is processed, and how it is obtained" (Riaz \& Chaudry, 2004 p.14). Generally, Muslims will avoid all that is known to be haram and those that are still unclear (syubhat) as there is a risk of spiritual or physical consequences either in this life (dunya) on in the Hereafter (akhirah). That is why Muslims tend to avoid consumption or actions that are still syubhat or those that cause them doubt (Wilson \& Liu, 2010). In advertising, Indonesian Muslims expect the advertised products to be purely halal.

"So, only products which are not in the syubhat or even haram category, mainly the ones which are clearly halal. Let's say that there is a conventional bank's advertisement but it has a hijabi as the customer service, then this is categorized syubhat by some people. Then let's say that there is a crab restaurant and even MUI has stated that crab is halal, but for some people, it is still syubhat. Also, when it comes to food, or relates to something, then some people might still reckon that it is a product in the grey area. It is better if products that can purely be for Muslims are used, which means they do not just advertise on the surface as if they target Muslim people, but they do something for the Muslims. Islamic ones are the biggest target." (Zahra)

As explained by Indri, Indonesian consumers are especially concerned about the halal status of food products. Therefore, products, which are haram, are not expected to be advertised on Indonesian television. Several products, which were mentioned during the interviews, included liquor and non-halal chocolate, which are believed to contain lard. Here, Indri fears that general Indonesians, especially the young people, would just accept anything that is advertised on television as something permissible to use or consume. However, there are concerns that this may not be true as the producers do not explain it in their advertisements, thus the halal status of the products is still questionable.

"Restriction for advertisement, perhaps food products, haram food...Ideally nothing like this should appear as in Indonesia, all foods must be clear, but well how to do it? There is no MUI halal logo... They just, I mean I only hear issues about a product which is not halal, but the advertisement keeps showing on TV, and the young people only think that if 
something is shown on TV, it is then safe. That is the mindset. Also about the beauty products that contain mercury or stuff which are on TV, people would think that they are alright as what they know is that it has passed blah blah blah, BPOM (Indonesian National Agency of Drug and Food Control/Badan Pengawas Obat dan Makanan) and so on. But we could not guarantee whether it has really passed the tests from BPOM...Like BengBeng is halal, but there is no statement about it. People simply perceive that it is halal as anything shown on TV is surely safe. So, I would love it if there are limitations about halal products. Only those which are undoubtedly halal can enter (be broadcast), so the products have a kind of cooperation with the broadcasting division." (Indri)

One indicator that is used to check the halal status of certain products is the halal certification that is given by MUI, which allows producers to use the official halal logo on their product packaging and communication materials, including advertisements. The MUI Halal Certificate is defined as written fatwa (Islamic scholars' decision), which states the halal quality of a product in accordance to Sharia (L. MUI, 2014). As Edi portrays, the absence of a halal logo causes doubt of whether a product is permissible for Muslims or not. Thus, halal labels make it easier for Muslim consumers in their purchasing decision. Farah describes that halal logos do not necessarily have to be present in advertisements as long as they are present on the product packaging. If a product's packaging does not have a halal logo on it, Muslim consumers must carefully read the label to ensure that there are no prohibited ingredients. However, the halal logo is not a prerequisite for purchase, so products with no halal logos may also be bought if it does not contain forbidden items.

"Hmm, it is just important. It's kind of doubtful if the product has no halal label." (Edi)

"The product, for example, it is safe to use. Halal...It is not necessary to show the halal label in the advertisement but it must be printed on the product ... Yeah of course I also check the ingredients. Pork, gelatine from imported products, colouring. There is umm, there are E [codes] right?... There is a red colouring from the insects. That, sometimes, eww... If it has halal label, then I would simply buy it, rather than matching it first. And if 
we actually know what the colouring is, we will never buy it again." (Farah)

For foods and other specific products such as cosmetics and medicine, the Indonesian consumers interviewed were also concerned about whether they had passed the inspections from BPOM (Indonesian National Agency of Drug and Food Control/Badan Pengawas Obat dan Makanan), an agency with the task of ensuring the security and safety of Indonesian citizens (BPOM, 2013). Concerns regarding the safety of products are still in line with halal, if observed from a more philosophical viewpoint. Halal actually implies purity, integrity, transparency and wholesomeness, which must be present in order to obtain and keep the consumer's trust (Shirazi, 2016). Wilson and Liu (2010) agree with this notion by stating that something that is halal is essentially pure, praiseworthy and beneficial. In the Qur'an the word halal is coupled with the word tayyeb, meaning good and pure. That is why Muslims do not only seek what is permissible, but also what is good and beneficial for them. This search for tayyeb has consequently led to the increasing production of food and services of the highest quality (Reuters \& Standard, 2016).

Farah believes that displaying a halal logo or emphasising the halal status in advertisements is not an obligation. However, the logo does reduce the perceived risk during the consumer buying process, which eventually shortens the time between the initial and purchase stages. The consumer buying process is a five-stage process, consisting of need recognition, information search, alternatives evaluation, purchase decision, and post-purchase behaviour (Blackwell, Miniard, \& Engel, 2003; Hawkins, Coney, Best, \& Hawkins, 2003). When consumers perceive a product to have risks attached, they employ risk reduction strategies during the second and third stages, such as relying on personal recommendations (Midgley, 1983; Perry \& Hamm, 1969), or seeking additional information about the product (Beatty \& Smith, 1987; Lutz \& Reilly, 1974). Farah has also explained the latter strategy, in that he would carefully read the ingredients on the product packaging to ensure that no haram substances were included. Seeking personal or word-of-mouth recommendations is also a common strategy that Indonesian Muslims take to reduce their risk of purchasing, or consuming, non-halal products.

"[I get information from] sharing, normally, and I also look for it myself in the shops, whether there is any [halal logo] on it." (Sigit) 
"Now, people's benchmark is social media to get some testimonials. So, people trust testimonials more than words from the company. I am also like that, like this, but I do not just believe one or two people, but how many people that say it. If there are a lot, then it is valid." (Yasmin)

Nevertheless, not all information through informal channels is reliable. Consumers are sometimes still left wondering whether the information can be trusted or not. Furthermore, there can still be news that certain products are not halal, even though it has already been granted a halal certificate from MUI. That is why Muslim consumers must also make their own decisions and weigh up how much risk they are willing to take from relying on shared information.

"all you can eat restaurant, I think. Hanamasa? Well they have meat. Do they have pork? There are some who said yes, some who said no... [I did not find any] inside [the restaurant], but there are some suspicions. Such as, in one boiling pot, it was previously used for that meat, then would it be halal or not. I have not searched more on the internet... [I am] just suspicious because there was news that it was not halal." (Hadi)

"Yes, Magnum, there are some who say that it is not halal as it contains a certain kind of milk or something, it is written there. But it already has a MUI logo then why would we feel afraid. For me, I still eat it, while some others might be afraid once they read that it contains that substance, they would not want it." (Sigit)

The cases above highlight that there are still trust issues regarding the halal status of products in Indonesia. Not all Indonesian consumers believe that halal-certified products have undergone rigorous examination processes. Some even doubt whether the halal logo is truly registered or whether it has been granted without any foul play. This doubt can be linked to consumer scepticism towards the halal label, which is defined as "the general tendency to disbelieve the halal label due to negative judgment about the certification process" (Aji, 2017, p. 190). From his research, Aji (2017) found that Indonesian Muslims demonstrate 
scepticism toward the halal label, and that this sentiment moderates the relationship between consumer attitudes towards the halal label and their purchase intention.

"Here, we have the halal logo but no assurance about its validity. Abroad, my husband's friend who works in the BPOM (Badan Pengawas Obat dan Makanan - Indonesian National Agency of Drug and Food Control) of that country said so. And they really test everything for halal certification. So, the government body is serious when it labels something as halal: the process, the final goods, everything. Here, we have no idea." (Yasmin)

"There are a lot of fake logos now. There are many people from MUI nowadays who behave like that. I see in the news that people are able to bribe them." (Vivi)

Another issue that has been brought up in the interviews is the potential controversy that a halal status can bring. Farah described a case when Zoya, a producer of hijab and Muslim fashion, posted a billboard stating that their hijab was halal even though it was not. She believes that the misinformation was based on Zoya requesting legal opinion from MUI rather than actually receiving a halal certificate. She continued by explaining that some consumers had negative perceptions of this as they believed it implied that other hijab products were also not halal. However, Sari (2016) reported that Zoya did receive a halal certificate (number 01171156041015) through the MUI office in West Java. The halal certificate was given based on the absence of haram substances when treating the materials used to make their hijab and Muslim clothing. This halal status can be determined by investigating whether pig gelatine was used as an emulsifier in its washing processes. Even though it was not Zoya's intention, their campaign to advertise the halal status of their products generated many conversations and even debates on the need for a halal logo specifically created for fashion products. Although it is not technically wrong for them to brand themselves as having halal hijab due to the sourcing and processing of the cloths, it may create unnecessary fear of the non-halal status of products. A week after announcing their halal certificate Zoya issued an apology for the controversy that it had caused (Yulianti, 2016). Wilson and Liu (2010) also observed that halal labelling has the potential to increase caution, fear, or suspicion among consumers. Although everything is essentially halal, unless 
stated otherwise, proliferation of halal labelling creates the image that everything must be labelled or risk being perceived as not halal enough.

"One point is that if it is rather controversial, let us say the halal hijab, was like a billboard...I understand, but halal labelling in this country becomes fatal and crucial, and it could cause misunderstanding. I read further and found out that it was about the fabrics, so not only hijab, as other fabrics might be mixed with something non-halal. That's the point, right? But basically, hijab is already part of Islamic Sharia, so when it is stated that hijab is not halal, the value of Sharia, I worry that it becomes not compulsory to wear it because people judge some hijabs are halal and some others are not. There will be a perception that it is better to not wear hijab, rather than wear one that is not halal. This is then wrong. Well, we know that marketing would always try to attract people. Furthermore, after further investigation, it was not actually MUI who did this. MUI was only asked, but did not publish any halal certification. Usually when MUI is questioned, they will give this [an opinion]. There was a talk show about this in TV One. There is no halal certificate issued by MUI." (Farah)

\subsubsection{5. $\quad$ Not Cause Mudhorot}

This fifth principle that is in line with Sharia is that the product that is advertised or the messages that it conveys does not cause mudhorot (negative effects leading to harm). This is closely linked with the concepts of halal and tayyeb as explained above, however the principle can be considered more generally instead of only focusing on the nature of the product. Related to this principle, Indri uses cigarettes as the most evident example of something that causes mudhorot, in this case, diseases.

“...Islamic product should not cause any mudhorot (harm) to the people.

So, it is halal religiously from MUI and although it is not a food product, it would not cause any disease, then Islamic advertisement must [be like that]." (Indri) 
Nevertheless, mudhorot can also be defined more widely as something that is believed to have the potential for causing negative effects on society. For example, Sari disagrees with the support that certain international brands have given to LGBT people. She especially sees it as a bad influence for her children. She fears that her children will have negative influences from it and eventually accept it as something normal. Although she has no objections towards LGBT people, she does not want herself and her family to be associated with it. In contrast, she believes that the brand should be putting forward positive movements that benefit society and do not cause controversy.

"Well, like that Nike one, they openly announced that, and there was another one, Honda if I am not mistaken, they clearly created a colourful advertisement and saying that they supported LGBT people. As the LGBT community is represented by a rainbow, right, so yeah like that... if they made such a movement, or if this brand supports it, that is definitely a big no no then. If you wanted to make any movement, then make a right one, something that enhances good things, not any weird ones. " (Sari)

\subsubsection{Issues of Ikhtilat}

Another issue that has emerged regarding Islamic advertising and its compliance with sharia concerns ikhtilat (intermingling of people of the opposite gender). This issue is actually related to that of hijab. In one sense, the hijab is a limitation of how much the opposite gender can visually see and how one's behaviour should also be restrained. Here, not intermingling is another layer of limiting the interactions between the opposite sex that is not permissible within Sharia law. Samsudin and Mahmud (2013) described ikhtilat as interactions between a male and female which includes admiring each other, and sitting closely which can lead to touching each other. Therefore, Islamic advertisements must also pay attention to the acceptable boundaries between male and female according to Sharia.

An advertisement that has crossed this acceptable boundary is that of Mio brand of motorcycles, which is commonly targeted to the youth market. In the advertisement a young male (Aleandro, a famous actor from an Indonesian television series) is giving a ride to a young female (Priscilla, an actress who performs alongside Aleandro in the television series) on his Mio motorcycle. Here, Indri finds it uncomfortable to see them sit so close to each other, as she believes it goes beyond the acceptable boundaries specified in Islam. However, 
it must be noted that Indri is someone with high religiosity and knowledge of certain Islamic principles. That is why this issue of ikhtilat did not occur during interviews other participants, especially the more moderate ones. As with the case of hijab, there were also differing opinions on the matter of ikhtilat.

"An example that is not in accordance is the advertisement of Mio where there are two youths, one male and one female. If I'm not mistaken the actors were Aleandro and Priscila. In the ad, they were riding on the motorcycle together, but their position was so close. In Islam, we are guided to not ikhtilat (intermingling between males and females), there are boundaries for non-mahram (related kins for which intermarriage is forbidden)." (Indri)

\subsubsection{Universal Islamic Values}

Despite the large amount of conversations regarding hijab during the interviews, the most commonly found theme among the various Indonesian Muslims was the content of the advertisements, which puts forward Islamic values. The values here are ones that are in line with Sharia and what Muslims have learnt from Islamic teachings. Nonetheless, many of these values can also be considered universal values that will be upheld by other people, including non-Muslims. Thus, the values can be generally accepted by anyone.

"Yes, the actor, the content, and everything needs to be Islamic. So, the presentation must be Islamic, as Islam requires hijab, and teaches Islamic values. For example, togetherness, helping each other, yeah the whole package." (Putri)

"Because the Islamic values are actually universal values, such as goodness, honesty, integrity, cleanliness, then it could be applied to other people, too." (Yasmin)

"Well, if it is Islamic then the models should also be Islamic. What are the boundaries? Well for example they bring Islamic values...It is pretty universal, manners, I do not know ... Like what, hmm ... like the ones with family values and stuff are still categorized Islamic, like that." (Gilang) 
One of the values that are highly upheld by the consumers is the family values and togetherness. Besides being described as Islamic values, they are also in line with Indonesia's collectivist culture. This may be why such values are highly accepted in the country and are also perceived as desirable values to be present in advertisements.

\subsubsection{Execution Strategies}

Besides the more fundamental components, which conceptualise Islamic advertising, analysis of the interview also uncovered more detailed themes, which can be applied in marketing, including execution strategies. These strategies include the preference of using soft-selling as opposed to hard-selling techniques, and also alternative timing decisions.

\subsubsection{Soft-selling}

Most advertisements in Indonesia are considered to be hard-selling. As illustrated by Sari, these types of advertisements become uninteresting to Indonesian consumers, as there is nothing else that they offer. With the abundance of hard-selling advertisements, an additional advertisement with such an approach would just be lost in the clutter. This can also be seen in Sari's example. She cannot remember the product or brand of medicine, just the general message that they tend to give to consumers.

"To me, uninteresting advertisements are ones which are too straight to the point. Seems like too much hard selling. Like the medicine advertisements back then, "just buy this then you would be pretty". "This and you can get instant healing", such straightforward ones... For me, if there is a lot of clutter then it would be hard to remember because everybody uses hardselling-appeals so we would not remember the hard-selling advertisement that they create. So, the advertisement needs to make a differentiation, or something different." (Sari)

In contrast, soft-selling advertisements are more memorable to the consumers. Alden, Steenkamp, and Batra (1999) describe soft-sell advertisements as those, which have content 
that emphasises the image over reasons to buy, by giving general associations with the brand. Here, Yasmin can remember that the brand is BNI (Bank Negara Indonesia), one of the stateowned banks in Indonesia. She can also remember that BNI was offering an insurance product, and that the imagery in the series of advertisements revolved around the story of a father who was a single parent, trying to raise his child. Yasmin emphasised the presence of a moral message in the advertisement, which can be linked back to the universal Islamic values as explained previously. In addition, Okazaki, Mueller, and Taylor (2010) found that advertisements with soft-selling appeals are related to a more positive attitude toward the advertisement and an increase in advertisement believability.

"Probably the ones that I like are advertisements with inspiring content. And it is more drama and not hard-selling that tells people to buy. But more that has a story, like the moral message, such as insurance from BNI, if I am not mistaken, the topic is about a kid who lost the mother. Then how hard it is for a father to take care and raise the kid alone and they make a series of it." (Yasmin)

\subsubsection{Timing Decisions}

Another consideration that marketers must consider when undertaking Islamic advertisement is when the advertisement should be aired. Overall, there are three possible times that Indonesian Muslims have discussed throughout the interviews. First is to show it at any time. This is the opinion of Indonesian Muslims who consider Islamic advertising as something universal, thus can be used by any brand at any time. The central idea is to spread good messages and universal values, which they believe should not have any time limitations. Putri believes that it is important to have more Islamic advertisements in Indonesia to be shown all the time. However, she realises that not everyone has the same awareness of the negative effects of un-Islamic advertisements. Therefore, there is a call for more Islamic advertisements to be used by various brands, and shown more frequently, without paying heed to the seasons.

"For me, it is pretty important. But I do not think that the society realizes that it is important. Because they do not realize these advertisements could 
teach us bad things. They do not even realize it. So, it is very important." (Putri)

So far, many of the Islamic advertisements are still seen to be very seasonal, surrounding certain Islamic moments such as the month of Ramadhan or Eid festivities. Ishadi (2011) noted that during the month of Ramadhan, television in Indonesia experiences a huge increase in Islamic themed programmes being broadcast, including sermons, talk shows, television series and music. Ramadhan is the holiest month in Islam, in which Muslims must fast from sunrise until sunset. Furthermore, Keenan and Yeni (2003) have added that beside the fasting, Ramadhan in general is a month of increased contemplation and spirituality. Thus, in their research of Ramadhan advertising in Egypt, they found that the advertisements focused more on messages of charity and that the characters are more conservatively dressed. This was seen as a form of respect for the values of Ramadhan and Islamic principles in general.

In Indonesia, the participants have also noticed an increase of more Islamic advertisements. Farah also noticed that when there is an increased of advertisements of certain products such as Marjan syrup which has become associated with breaking the fast during Ramadhan or Eid al-Fitr festivities in Indonesia. There are Islamic values shown in these advertisements such as the family, and asking for forgiveness. The theme of forgiveness is especially important during the Eid al-Fitr moment as Muslims believe that after one month of fasting and increased spirituality, they can return to fitrah, as a pure soul without any mistakes. Thus, they must also as for forgiveness from their relatives or friends if they have previously done them wrong.

"Ramadhan advertisements are like the ones I previously mentioned, there would be stories about the relationship between mother and children. Eh what is that syrup ad or I forgot some kind of food.... Yeah, maybe it is adjusted to the theme, it is very particular in Indonesia. Like there is already an image. So, when there are already Marjan syrup or sarong advertisements starting to show up, it means that we are welcoming Ramadhan already. So it's like a particular thing... Yeah, all Islamic things are those during Ramadhan or Eid al-Fitr which show Islamic values. Well maybe people perceive those as the examples. Like Eid al-Fitr ads, like 
asking for forgiveness. Now that is one of the Islamic values, right?... But again, it goes back to the event, moment, perhaps it can be made more Islamic when Ramadhan and Eid al-Fitr comes." (Farah)

Another moment that can be used for Islamic advertisement is before the broadcast of adzan (call for prayer), especially Maghrib prayer (at the time of sunset). This moment is particularly relevant for advertisements on television, as the most popular media in the country. In Indonesia, the call for Maghrib prayer is broadcasted by most national television stations and accompanied by a mini movie or illustrations of nature. Therefore, it would be a good idea to link this time in which Indonesian Muslims are getting ready for prayer to more Islamic advertisements which put forward religious values and messages. In addition, Doni also notes that this is the prime time when many Indonesians would be watching television, thus the advertisements will receive a wide audience compared to other times of the day.

"So, before Maghrib, like it is important to have more religious Islamic advertisements, I think there are already some of them like that." (Doni)

\subsubsection{Products and Brands}

Certain products and brands have already formed an Islamic image in the eyes of Indonesian Muslims, thus advertisements of these products and brands are automatically deemed as Islamic. Some brands that were mentioned throughout the interviews include Wardah and Sunsilk for hijab. Wardah is the first cosmetics brand in Indonesia that has put forward its halal status as one of the main messages in its advertisements. However, its appeal is not just from the halalness of their products; the advertisement has been executed so well that it offers a whole Islamic package. Caca has expressed that the Wardah advertisements have resulted in a good image, and Zahra explained the particular elements that makes Wardah a good example of Islamic advertisements. Although the advertisements have a mixture of hijabi and non-hijabis, the clothing was still within the boundary of politeness. The language and movements in the advertisement was also smooth, as expected from a good Muslim, who must be modest in all aspects of life.

"Yes, so I think Wardah has good imaging in the ad and is really cool, good." (Caca) 
"From what I see, Wardah have put effort in to show that they are Islamic. Wardah were initially total Muslim, halal cosmetics for Muslims, but now they have changed as they could expand the market, not only for Muslims, right. But that is fine, from the business side, which I happen to know it personally. I know that for the test and everything else they do not use animals and they assure the halalness of their ingredients. That means that they have already done something with the product, and in the advertisements, none of Wardah's advertisement with both hijabi and nonhijabi characters act in an impolite way. They also use smooth, polite language; the movement is also smooth, nothing like, the Javanese say "biyayakan", meaning too active, not like that. So, they seriously try to be consistent to Islam. That is a good example." (Zahra)

Shampoos for hijabi are also mentioned, with Sunsilk as the most common brand. As Sunsilk is aiming for a specific target market, their appeals are also suited to their target audience, women who wear hijab. Yasmin especially makes note that these hijabis are really concerned with their religion, thus they would not take off their hijab even though there are some hair and scalp problems that are commonly associated with wearing the hijab in Indonesia. As Indonesia has a hot and humid climate, wearing the hijab is often perceived as hot and there would be less air circulation in the head area, especially as people are often sweating. Thus, women who wear the hijab may experiences more greasy hair, itchy scalp and even dandruff. That is why brands such as Unilever's Sunsilk and P\&G's Rejoice have launched a special product variant with ingredients, which cater for these hijabis. Sariayu, a local Indonesian brand, also has a series of products for hijabis, which includes shampoo, conditioner, hair tonic lotion, and hair mist (Sariayu, 2015). The increase of products that are especially targeted for hijabis reflects the increasing number of women who have taken to wearing the hijab, and at the same time shows an increasing public piety. In contrast, approximately two decade ago Brenner (1996) observed that wearing the hijab is still an uncommon practice in Indonesia.

"So, they launched those hijab series of Sunsilk in the beginning of Ramadhan. It was their effort to present the product and create an Islamic marketing image. As they see the target market. For the middle class who 
really pays attention to religion, they would not take their hijab off. Meanwhile wearing hijab makes the hair greasy, itchy, and so they offer a solution." (Yasmin)

Moreover, there are some products, which have been more traditionally linked with Islam. Some clothing items that have been culturally linked with Islam include sarong, koko (Islamic prayer shirt), peci (prayer cap, traditionally made of black velvet), and mukena (prayer garment for women). Other products that are only targeted for Muslims include umra travel (mini pilgrimage to Mecca) and payment of zakah (obligatory charity). As in the case of shampoo for hijabis, the advertisements of these products are commonly accepted as Islamic advertisements because they have a more specific target market: the Muslim population.

"You know sarong? The advertisement is about how to... It's about the quality of the fabric and how people are proud to use it." (Ani)

"Local TV advertisements which are Islamic... Maybe umra advertisements. I think others rarely advertise." (Doni)

\subsubsection{Public Figures}

Another indication of Islamic advertising is the use of public figures who are deemed as pious and have a religious image. These public figures can be categorised as celebrities with an Islamic image, religious preachers, and religious fictitious characters which are especially created for an advertisement.

Celebrities with an Islamic image are generally those who wear hijab in their daily life such as Inneke Koesherawati, Laudya Cynthia Bella, Dewi Sandra, and Allysa Soebandono. These celebrities did not wear hijab in the past, but are already familiar as celebrities in the eyes of Indonesian consumers. After they started wearing it, different companies approached them to advertise products, which more targeted for Muslims. For example Inneke Koesherawati was one of the pioneer celebrities who donned the hijab. Jones (2016) noted that by wearing the hijab, Inneke Koesherawati created a blend between beauty and character, which suggests that consumption and religion are not mutually exclusive. 
"Wardah was a pioneer in stating that it is halal. It was Inneke, the model... So, they later, how to say, they choose the model which still represent Islam, who is it, Dewi Sandra." (Yasmin)

In addition, there is Dian Pelangi who has become a Muslim fashion icon in Indonesia. Dian Pelangi is a designer for Muslim wear, who is also the founder of Hijabers Community in Indonesia (Riduwan, 2013). As Kemala explains, Dian Pelangi was present in the advertisement of a watch. Even though the watch is ordinary, meaning it can be used by anyone, Muslims and non-Muslims alike, the presence of Dian Pelangi creates an Islamic image of the advertisement of a whole. Thus, the use of certain celebrities such as Dian Pelangi can have a halo effect on the ordinary product.

"Dian Pelangi is also shown in Charriol watch advertisements, so it gives Islamic impression. While in fact the product is just ordinary, only a watch." (Kemala)

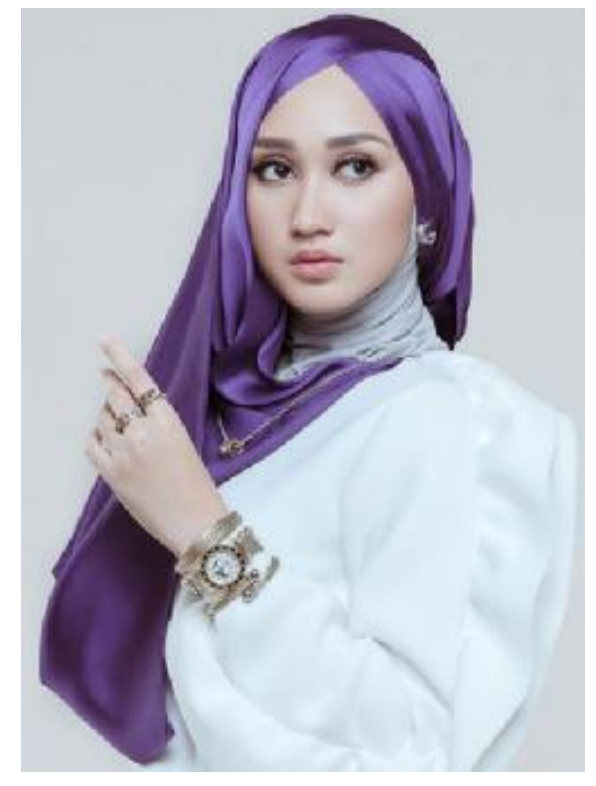

Figure 2. Dian Pelangi for Charriol

Source: Anjani (2015)

Kemala also talked about the use of Islamic preachers. Ishadi (2011) listed a number of popular preachers, who have almost celebrity status, including Aa Gym (from 2000), Arifin Ilham (from 2004), Ustad Jefri Al Buchori (from 2004), Yusuf Mansur (from 2006), and 
Mamah Dedeh (from 2008). As they have become television icons, companies have also approached these preachers to advertise their product. For example, Sudibyo (2013) studied Mamah Dedeh as the endorser of Larutan Cap Kaki Tiga (a medicinal drink for heartiness) and found that there is an effect on the image of the brand as a whole, with trustworthiness being the most important dimension. Thus, these celebrity preachers can affect the image of products and brands to make them more appealing to Muslim consumers.

"The star of the advertisement makes the advertisement Islamic. For example, we look for Islamic preachers. ” (Kemala)

“...also on TV like Mamah Dedeh, all is actually media for people to learn about Islam." (Yasmin)

Furthermore, marketers have also been observed to create fictitious characters with desirable, Islamic characteristics. Some characters that were mentioned include Mas Medok, which will be described in a later discussion (4.3.2 Valuing Local Content and Actors), and Ukhti Sally. Here, Yasmin described Ukhti Sally as a young Muslimah (Muslim woman) wearing hijab. She is actually the icon for Pasal, a brand of Muslim wear, which sells hijab and clothes. At first, Ukhti Sally was depicted as a cartoon character in its Twitter, and Instagram account. However, later on, the character was also used to create a YouTube movie in which there was an open casting for who would become the Ukhti Sally character. Even though the style of hijab sold tends to be more conventional (longer hijab, below the chest), the use of the Ukhti Sally character made it more playful and relevant to its young target market. Although Yasmin is not the main target market, she still follows the progression of communications by the Pasal brand though its use of various social media. That is because the messages are still relevant for her as a Muslimah, and she finds the character and her story interesting to follow.

"So, they have an endorser; Ukthi [sister] Sally, she is the icon, for instance, Wendy is a girl with ponytails then it is Ukhti Sally for Pasal. A young Muslimah wearing hijab. Ukhti Sally was the leading role." (Yasmin) 


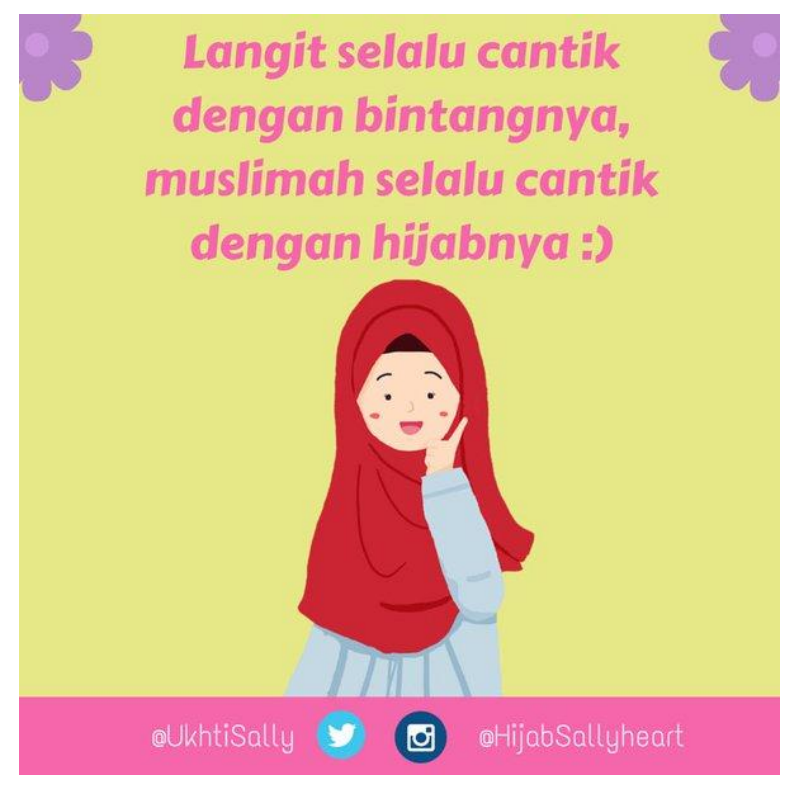

\section{Figure 3. Ukhti Sally (a Muslimah is always pretty with her hijab)}

Source: (Sally, 2015)

\subsection{Negotiating Religion and Culture}

Roth (1995) posited that both religion and culture have significant impact on global marketing practices, including that of brand imaging and advertising. In Saudi Arabia, Luqmani, Yavaz and Quraeshi (1995) believe that religion has a greater affect than culture on the practices of advertising. Yet, this relationship is more complicated in Indonesia as religion and culture tend to be negotiated and interact in a way unique to the context.

As Islam is a relatively new religion in Indonesia, the Indonesian people were previously already familiar and practising other religions and faiths, including Buddhism, Hinduism, and Animism. Therefore, the practice of Islam is sometimes coloured with more traditional faiths and local customs, forming a kind of acculturation. Vatikiotis (1993, p. 120) observed that in almost all parts of Indonesia, "traditional, culturally based law, or adat, takes precedence over strict Islamic customs". He especially noted that in Java, many aspects of the previous Hindu-Buddha era have become mixed with Islam. Thus, he believes that syncretism and tolerance seem to be innate to Indonesian society. However, since Vatikiotis made those observations (1993), the social landscape in Indonesia has changed; Islam has become increasingly significant to its adherents in the country. 
Yasmin elaborated on how her father's family, especially older generations, mixed Islam with traditional Javanese beliefs. This became a challenge for her family in applying Islam in the family, as there is also reluctance to perform prayer, even though it is one of the basic obligations of Islam. Many of the Javanese beliefs are also contradictory to Islamic beliefs and teachings, such as the reliance on mystical calculations and the belief that certain objects can have powers, such as for strength or long life. In contrast, the foundation of Islam emphasises that Allah is the Almighty God and that believing in anyone or anything other than Him (known as syirk) is the greatest sin possible in Islam.

However, Yasmin also observed that this situation began to change from the early $21^{\text {st }}$ century. Since then her family has become more accepting of Islam. She especially noted the difference in her generation, such as among her cousins, that they have been applying Islam more fully and have a stronger adherence to the religion. This growing religiosity was not only within her family; she also observed that Indonesian Muslims in general were more willing to apply the "straight" version of Islam; the religion that is purer without the influence of traditional cultural belief.

"My family is a kind which is really Javanese, very Kejawen [Javanese religious tradition]. We are of ningrat [royal Javanese blood], so it is very hard for Islamic values to be fully applied. So, my family started to pray in around 2000s. My generation and my cousins are stronger in applying Islam. I guess the shift of religious values was the one that caused others' awareness for people to apply Islamic values, then it also affected the market...in my dad's family. So Kejawen. They do not want to pray, they even follow Primbon [Javanese traditional calendar and its rituals] to do fasting. Then the mystical things, like keris [Javanese knife, believed to have mystic powers], and stuff. So, it is a bit tough, from my dad's family. We try to reach them to apply Islam. A form of Islam with straight belief, not with those things. But alhamdulillah, we have destroyed those things since the passing of my grandfather." (Yasmin)

Although Indonesian Muslim are growing to be more pious in applying Islam in their daily lives, it does not mean that the influence of culture is eliminated. That is why, in creating advertisements, the consumers believe that companies and advertising agencies must take into consideration the commonly accepted culture in Indonesian society. Most of these 
cultural considerations revolve around issues of decency, exposure and sex appeal. This finding partly supports previous literature which states that no sexual appeals must be used in advertising (Mohammad Saeed et al., 2001). However, Caca has no problem with mild use of sex appeal, such as what is used in the Axe advertisement that is shown in Indonesia. She contrasts the advertisement with a more "vulgar" version that she has seen of the Axe advertisement that is shown abroad. Caca even described that the Axe advertisement abroad degrades the dignity of the women who chase after the man who used Axe. The women were willing to take off their clothes in public and present themselves physically to the man, without considering their self-worth.

Some participants also take into consideration the local culture of specific ethnicities, such as Javanese. As a Javanese, Ani believes her culture to be very strong and characterizes her cultural teachings to those of other ethnicities. Javanese people are "taught to be more polite and more religious". Honorifics are an important part of the culture. One cannot just directly call other people by name, but must refer to them using Sir, Madam or with other appropriate honorifics. Names can be used directly only among people of similar ages who already have a close relationship or with younger people. Honorifics must always be used with people who must be respected, such as elders.

“...mostly as Javanese, the culture is very strong and it's like we are taught to be more I mean you know the custom is very strong and we are taught to be more polite. We are taught to be more polite and also more religious... like I said before culture influences everything so I think that the advertisement should consider the culture where it will be broadcast or where it will be you know advertised. It should consider the culture of the people." (Ani)

"Maybe the point is more towards guiding them to understand about our culture, like what is not allowed. What is decent and what is not, what is allowed and what is not, more to that, I guess. It must take into consideration... General or common culture in our society, the one which is perceived as decent." (Mira)

"Oh yes, for example, culture. The culture because we may be more to the East, more Eastern. So maybe if abroad I sometimes see if I am in the hotel there is an ad that may be more vulgar. Like this advertisement, the Axe 
effect. In Indonesia, it is still standard. Well if it's overseas, I forgot what country. That girl would eventually open her buttons. It's not possible in Indonesia. Basically, so super-duper sexy... Later if we let the advertisement enter, then maybe FPI [Front Pembela Islam - Islamic Defenders Front] and such would say "wow indecent". Later even the product could face problems." (Caca)

The concept of Eastern culture also emerged in the findings. Eastern culture assumes that there is a divide between the East and the West. Indonesian culture is often associated with Eastern culture and contrasted with that of the West (most often associated with the United States of America). Irawanto (2009) looked at the cultural dimensions proposed by Hofstede and Hofstede (2005) and by the GLOBE Project (House, 2004) in which he drew some conclusions on national cultural dimensions that generally differ between West and East. He stated, "Eastern people tend to show collectivist behaviour, which emphasises harmony and social order". Indonesians often believe themselves to be and are often described as friendly, peace loving, and open handed (Mulder, 1994). This is consistent with the descriptions derived from the interviews, where within the Eastern culture one is expected to have selfcontrol, maintain good behaviour, ensure the comfort of others, treat others in a respectable manner and build relationships with other people. This collectivist nature, leads Indonesians to always mind the feelings of others, and thinking carefully before one speaks or acts. Indonesians take care that their behaviour does not upset others (Irawanto, 2009). That is why in advertisements, Indonesians also expect that there are no parties that would feel insulted or degraded.

\subsection{A Challenge to the Standardisation versus Localisation Debate}

The interplay between culture and religion also emphasises the challenge that marketers face when creating advertisements for Indonesian Muslim consumers. On the one hand, Indonesian Muslims place importance on universal values such as family, togetherness, and helping other people. This implies that standardisation is an advertising strategy that can be used in Indonesia. Standardisation can especially be done in the form of pan-regional advertising. 


\subsubsection{Gaining Inspiration from Thai Advertisements}

Many of the consumers have seen and were affected by advertisements in Thailand. Although the advertisements have not officially been shown in Indonesia, especially as the advertised products are not available in the country, they have been shared on social media platforms and become viral as inspiring advertisements. The Thai advertisements are appreciated because they often have a touching story, which ends with a moral message. The advertisements not only focus on the product they are trying to present, but also communicate a message to the audience.

One example of a Thai advertisement that was mentioned during the interviews is an advertisement by Advice, a distributor of IT products such as computers, laptops and tablet. Although Putri forgot the details in the advertisement, but the essence and message it delivers is still memorable. The advertisement begins with a couple and their young son who are looking to buy a tablet. They picked one of the tablets, which they observed had many games. The tablet was handed to one of the staff in the Advice store so that the family could purchase it. However, when the Advice staff asked and found out that the tablet was in fact for their five-year-old son, he said that they may come to pick-up the tablet after 7 years. He goes on by explaining that 12 years old is the right age to start handling a tablet and that while the son is still young the parents should spend more time with him so that he can grow to know tenderness and love, instead of becoming a heartless person. During the last five seconds of the 45 second advertisement, the family stand in front of the store with the Advice staff while he announces the tagline of the advertisement: "Advice, only good ones for you."

On first impression, it seems that the advertisement is counterintuitive as the staff actually reject a potential sale for the day, but they stay true to their tagline by putting the customers' interests at heart. By putting forward this message, the advertisement has extended beyond their target audience and is appreciated by people all over the world, including many Indonesians, as was found from the interviews. The Thai advertisements have become very memorable to them and are role models of what they hope advertisements in Indonesia could be like.

"Thai advertisements, as an example, the ones that I saw previously were

Thai ads. They always have stories which are impressive." (Farah) 
"Well, the ones that I would say are very interesting are typically from Thailand. So great, so on point. For example, if someone helps somebody else, at the end of the day that person would also get help. There is a family, who wanted to buy a tablet [for the child], but the parents did not permit it because he was not yet eight years old. There are just a lot of Thai advertisements which literally deliver it..." (Putri)

"In Indonesia, it is still rare to create advertisements based on stories, whereas there are a lot in Thailand. The idea comes from a Thai insurance advertisement which touches us so that we even cry watching it, but in the end, it is about insurance, but people do not really think to protect their beloved ones with insurance but they are moved already with the story." (Yasmin)

"Inspiring ones, there are many of them abroad, like Thai advertisements maybe, they have stories and then only at the end do they insert a little bit about the product." (Gilang)

Another strength of these advertisements is also their ability to become viral. Many Indonesians have come across the links to these advertisements through Facebook or other social media. Often, the links are shared with headings such as inspiring or best advertisement, which causes the consumers to be curious and eventually click on the links. The Thai advertisements do not disappoint them, as they are proven to be touching and leave a lasting impression on the viewers. Some consumers who watched the Thai advertisements also proceeded to tell their friends and family about them or shared them again through their personal social media accounts.

Furthermore, the Thai advertisements generate so much awareness and attention because they are not just focused on trying to sell their products. In contrast, Indonesian consumers expressed their critique of the abundance of advertisements in Indonesia that only have a "selling orientation". Indonesian advertisements are judged to be straight to the point, only focusing on the products and urging consumers to buy them. However, in order to gain consumer attention, advertisements are asked to offer additional benefit and value from the 
communications in advertisements. Otherwise, they will just be lost in the clutter and do not leave a lasting impression on the consumers.

"For me, advertisements in Indonesia are more to sell products, even though there are some good ones like brushing teeth so that we do that as a routine, but like cigarettes, energy drinks, they just want money, that's what I think." (Ranti)

"Actually, it is not good to show the product too often. Like Freshcare, isn't it annoying, like so focused on selling. I do not really like such advertisements. So, I like it if it has a story..." (Kemala)

Indonesian consumers actually do not mind watching advertisements from Thailand, and actually prefer it rather than local advertisements. When local advertisements pop up, they would just skip it, change the channel or simply do not pay attention. However, they do not mind watching Thai advertisements, and some even intentionally seek them out on YouTube. This emphasises the possibility of using standardised advertising, such as a pan-regional strategy, as long as it is executed correctly. Indonesian consumers appreciate advertisements, which have an interesting story that they can follow, and also contain a moral message or desirable values to be presented in them. As Islamic values are seen as something universal, advertisements from abroad which deliver these values can also be considered Islamic.

"I mean the content is also like that, in that one the wife did not wear hijab. But the point is about closeness and harmony. Those kinds of things are also part of Islam." (Mira)

"Like humanity, integrity, love, these are Islamic values which ideally every Muslim has; the ones that could be spread to others, as well. So how to say, the values that are ideally adopted by Indonesia are not supposed to be far from Islam's. As Islam is universal and its religious teaching is not different from other religions, ... Such as parents shall love their children, children should do good to their parents, then be kind to the neighbours, care about those living in our neighbourhood are actually Islam's universal values which would touch people more once applied in marketing and business through advertisements." (Yasmin) 


\subsubsection{Valuing Local Content and Actors}

Despite the Indonesian consumers' acceptance of advertisements from abroad, they also appreciate the use of local content and local actors in advertisements. This makes the advertisements more relevant to them. Edi believed that foreign advertisements could still be accepted in Indonesia, but found it better if local actors were used as the stars of the advertisements. If foreign actors were to be used, he would like the majority of the actors to still be Indonesian. Moreover, Indonesian consumers also observed that several advertisements that were made in Indonesia are also used abroad. This increases their appreciation of the advertisement and also instils a feeling of pride.

"I see no problem about that. But it is better if they use Indonesians. So, it is just more suitable for us, like the one, that female one, what was that, L'Oréal advertisement maybe? The one presenting Raline Shah and her hair, it is also used abroad, also Julie Estelle if I'm not mistaken is also used abroad, so this makes us proud... But if possible, the proportion is at least 60-40. 60 percent are Indonesian models as the stars of the ads." (Edi)

“...when I speak about Singapore and Malaysia some of the Unilever advertisements are taken from the Indonesian version which are adapted in English there. So, somehow there are not many multinationals, which change it [the advertisements] into Indonesian, on the contrary, as it is creative and cheap they would create in Indonesia for at least Southeast Asia or something. So, I do not see many advertisements being translated or what. In fact, there are even more local advertisements perhaps the advertising industry in Indonesia has become more creative." (Caca)

Moreover, Indonesians like to gain more information about their country's natural beauty and local cultures. Indonesians are proud of their natural and cultural heritage, but the diversity is still underexplored, thus Indonesians are always looking for opportunities to learn more about their rich heritage. As the archipelago is so vast, many Indonesians have not had the opportunity to explore all of it, thus they enjoy seeing and learning about the local cultures or the unexplored nature of more remote areas. Related to this, Tegar mentioned an 
advertisement for noodles, which showed local cultures from Sabang (the most Western point of Indonesia) to Merauke (the most Eastern point of the country).

"A good example of interesting advertisement is Axe; do you know that one? Axe was made, who is it, Keenan Pearce, he makes travel documentaries, like his travel to the villages but it does not advertise the Axe, but it advertises his journey in teaching people. Then it is also documented in the form of an advertisement. As I know, he also uploads his videos on YouTube. It is just interesting, the advertisement, because we could see another side of what it is, he is in the villages, we could see the life there." (Yuda)

"A noodle advertisement I think, instant noodles. Yes, sometimes they showed other area's icons. And the traditional clothes from other regions. Actually, they wanted to show that everyone throughout Indonesia consumes instant noodles; eats their products from Sabang to Merauke." (Tegar)

Putri described an advertisement from Bukalapak, an Indonesian online shopping website. Bukalapak is known for its funny and creative advertisements. The "Mas Medok" advertisement that she mentioned was actually part of a miniseries that Bukalapak created before the Eid al-Fitr moment. The first episode was uploaded to Bukalapak's YouTube channel in February 2016, while the eighth and last episode, in which the character was going back to his hometown, was uploaded in July 2016. Mas Medok is depicted as a hero, originating from Java, thus his name is Medok, meaning thick Javanese accent. 'Mas' is also a Javanese honorific used for older or respected males. Uniquely, he is a hero, which only uses his fingers to help other people. Throughout the series, his fingers were used to show directions on a map, capture flies that were bothering a food seller, fighting of villains, and many others, including helping people sell items on Bukalapak. Therefore, there is still some product knowledge for the viewers when watching the videos.

In the episode that was described by Putri, going back to one's hometown is a tradition that many Indonesians go through at the end of the Ramadhan month so that they can spend Eid al-Fitr with their extended family. Many Indonesians travel to larger cities, especially Jakarta, 
to make a living and will only return during this period. That is why it is a special moment that is very relevant to many Indonesians. Knowledge of local wisdom and traditions such as this increases the attachment that consumers feel with the advertisement and thus increases their willingness to actually watch the advertisement instead of just skipping it. Consequently the Mas Medok series was also awarded as the Top 3 Video Ads of January-June 2016 by Google Indonesia, due to its popularity and the buzz that it generated (Ruhiyan, 2016; Wira, 2016).

"There are a few that present something from the people, one of them is Bukalapak, the "Mas Medok" one as it was a hit, right, he was going back to his hometown during Ramadan, we were also going back to our hometown, and it was funny, there was a message in it." (Putri)

"Or another example of what I enjoy is BukaLapak.com advertisement, it has a continuous story and it is so 'daily life', so it just feels like watching a drama series, while behind that it is actually Bukalapak. So, it makes us want to see more of it. Yes, perhaps because it is related, so we connect it with our own experiences, it is just quicker. (Sari)

\subsection{Images of the Self}

According to De Mooij and Hofstede (2010), the concepts of self, personality, identity and image were developed in the individualistic Western world. In collectivist cultures, such as Indonesia, the self is interdependent to the social environment, and people's ideals and behaviour are influenced by contextual factors, including their status in society (Church et al., 2006).

\subsubsection{Negative Images}

Discussions of negative images surround two main topics, namely inauthentic images and sensual images. Inauthentic images are mostly connected to what Indonesian Muslims perceive as fake images of beauty, which do not represent real people, especially the diversity of beauty. Meanwhile sensual images are considered vulgar and verge on pornography. These negative images can be understood from previous literature on offensive advertising. 


\subsubsection{Inauthentic images}

The first negative image that was discussed during the interviews was an inauthentic one, or one that participants described as fake. Most of the discussions surrounding inauthentic images surround the topic of beauty. Many beauty products in Indonesia advertise the ideal beauty as having white, pearly skin. Saraswati (2010) has also noted the abundance of advertisements for skin-whitening products in Indonesian media, and that these products are the most popular among the cosmetics industry in the country.

Nevertheless, Indonesian Muslim consumers are now realising that there is no single definition of beauty. Indonesians are proud of their diversity and consumers such as Farah and Putri believe that diversity in skin colour should also be embraced and considered in advertising. That is why depiction of white skin as the single image of beauty becomes inauthentic as compared to the diversity of skin colour seen in daily life. From a cultural perspective, this inauthentic image of beauty can also be linked to ethnic self-awareness, a situation in which someone becomes aware of their ethnicity (Forehand \& Deshpandé, 2001). As Stayman and Deshpande (1989) found in their study, ethnicity not only about who one is, but also how one feels and the situation that they are in. When seeing advertisement of skinwhitening products, Indonesian Muslims such as Farah and Putri do not see their ethnicity being depicted in the advertisement, as they realise that the real image of Indonesians is not just pure white, but encompasses a wide range of skin tones.

An additional point that Farah makes is that the emphasis on beauty tends to lead to revealing of the awrah. Thus, it goes against Islamic teaching of covering the awrah; showing that area off instead. Showing off beauty and intentionally trying to attract the opposite sex is known as tabarruj, and is forbidden in Islam as it goes against the Quran (Samsudin \& Mahmud, 2013). In the Quran, surahs (chapters) Al-Ahzab and An-Nur emphasise the need for modesty in dressing and behaviour. Thus, overemphasis in beauty and showing off this beauty would not be in line with this concept of modesty.

"I hate advertisements' portrayals of fair skin as the only idea of beauty; basically, the image of beauty. I mean that just does not matter... That's wrong. I reckon that it is a false perception. wrong doctrine. In other countries, there is no such thing as fair beauty. Not everyone has fair skin." (Farah) 
“... a celebrity shows off her body to sell detergent, just because she uses the detergent, then the clothes smell good, she uses it in the laundry and she wants to give it as she is beautiful, with skin like porcelain, which is revealing awrah in one point, and the second, it is lying." (Putri)

\subsubsection{Sensual images}

The second category of negative images that were found during the interviews is sensual images, meaning those that are using sex appeal. This can still be linked to the concept of tabarruj as explained above. As Sari illustrates, there are three elements, which make the advertising sensual, namely the clothing, behaviour, and language. She gives an example of candy advertisements from 2011. There was actually a range of candy produced by PT Unican Surya Agung with the brands Suteka (milk tea candy), Sukoka (milk coffee candy), and Mint Choka (mint chocolate candy). Their advertisements have different settings, but similar levels of sex appeal. For example, the advertisements for Suteka feature a couple that were just sitting down to watch a movie at the cinema. The man's clothes were quite ordinary, just a T-shirt. However, the woman was wearing a sleeveless dress, which accentuated her breasts and cleavage. After they both sat down, the man suddenly delivered his request "Mimik... Mimik Cucu (Drink... Drink Milk)". The language used here is not formal Indonesian (Minum... Minum Susu): instead a playful or cute version of the language, usually used by little kids or in intimate situations. Furthermore, the request was made while the man was looking at the woman's breasts, which emphasises an erotic tendency given the words that he used. The advertisement proceeds with the woman taking out a strong Suteka candy from the chest area of her dress. There are many elements here that Indonesian Muslims would find offensive, including not adhering to the polite dress code and using strong sexual appeal.

"Weird ones, there are, the advertisement that is a bit offensive, like presenting a very sexy female actor. It is very offensive, right. So, what do they want to sell, actually? They only want people's attention by presenting females with mini clothes, for example, strange dancing like that... They used sexy woman and she said, 'eat milk tea candy', it was very offensive to the milk with the way she wears that sexy dress." (Sari) 
In contrast, a subtle use of sexual appeal that is still acceptable within the Islam can actually be acceptable and even favourable to some Indonesian Muslims. When asked about advertisements that she liked, Ani describe a Lux (Unilever brand) soap advertisement featuring Bunga Citra Lestari and her husband, Ashraf Sinclair. In their advertisement, the main message was to awaken the vibrations of love (Putri, 2014). Although the advertisement showed Ashraf Sinclair appreciating Bunga Citra Lestari's skin, it can still be seen as something that is acceptable as they are legally and religiously married (within Sharia), thus instead of being offensive, Ani finds it to be a romantic moment that she also desires to have. Research by Anatariona (2014) also found that using Bunga Citra Lestari as the celebrity endorsement has a positive effect on advertising, which in turn leads to purchase intention from Indonesian consumers.

\section{"Lux. Bunga Citra Lestari with her husband. Yeah I mean it's like you know it's romantic moment." (Ani)}

\subsubsection{Ideal Images}

For Indonesian Muslims, ideal images in advertising are not only seen in terms of physical appearance, but more in terms of character. Thus, the ideal images in advertisements are those that depict good Muslim role models: virtuous characters that are in line with Islamic teachings. The evidence of this is how Islamic advertisements sometimes use religious preachers as their endorsers. However, a virtuous character can also be created through the stories in advertisements, such as was the case with Mas Medok. These ideal characters are appealing to Indonesian Muslims, as they are in line with the ideal self that they would like to be: a self that is more pious and more religious. Thus, the characters, story and messages blend together to educate or remind these Muslim consumers of certain Islamic teachings and principles (dakwah), which can incrementally raise their awareness of the intended message.

Sari gave an example of Pepsodent Herbal (a toothpaste brand from Unilever) during Ramadhan, which encourages an act of charity during the Ramadhan month. Through her elaboration, it can be understood that the physical appearance of the mother did not matter to her, even though her awrah was not properly covered. However, she found congruence between the character of the mother and her own self, whom she describes as humanistic. Thus, messages such as these touch Muslim consumers given that they serve as reminders to become a better person and a better Muslim. 
"Pepsodent Herbal which says, "Do not throw the package away, this could be used to donate for others' suhoor meals", like that. That actually teaches about charity, teaching about kindness. That is Islamic although the mother only uses a head scarf, well it's okay actually. The important thing is... I mean a head scarf, not a proper hijab which actually shows [her hair], that is actually fine." (Sari)

This is in line with Yasmin's elaboration that learning is a continuous process in life, in which Islam gives guidance to Muslims. Although one might already have a certain level of knowledge, it is still welcoming to have reminders of Islamic teachings depicted in advertising. Thus, everything that Muslims see or do will be matched with their idealism and faith to see whether they are congruent or not.

"Learning itself is a continuous process, although we have learned about something, that does not mean that we should stop... If we are in the society like this, we learn about life, then we match it with idealism, then it just goes like that. Then why still hang on, it is because by being on this path [Islam], our life becomes peaceful, so we have a guidance." (Yasmin)

\subsection{Effects of Islamic Advertisement}

After discussing congruity with ideal images of a more pious character, this section will discuss the effects that Islamic advertisements have on Indonesian Muslim consumers. This discussion will be divided into two: effects on emotions, as well as attitudes and behaviour.

\subsubsection{Emotions}

Islamic advertisements bring positive emotions to Indonesian Muslims. Yasmin described these advertisements as being able to make her feel more calm and peaceful. In previous literature, emotions as results of stimuli such as advertising have been classified into dimensions of pleasure, arousal and dominance (Mehrabian \& Russell, 1974). Here, the calm feeling can be considered, as the Muslim consumer is experiencing pleasure. This can be 
contrasted to the annoying and offense that these consumers feel towards un-Islamic advertising, as explained in the discussion of negative images.

"More calm. Honestly, I feel more peaceful. At least it could be listed as my evoked set. So, at least, if one day there is somebody who asks for reference then I would refer to that." (Yasmin)

\subsubsection{Attitudes and Behaviour}

Islamic advertisements can also have an impact on Indonesian Muslim consumers' attitudes and behaviours. Caca described how watching the Wardah advertisement for compact powder left a very positive impression on her. The emotions of watching the happy bride on her wedding day translated into a positive attitude. In turn, it also affected her behaviour in two ways. First, it led to positive word-of-mouth regarding the Wardah brand and products. Here, Caca shared her experience of telling her mother about it, and about plans to buy it. Thus here, purchase intention was formed, which eventually led to her purchasing the powder.

"The advertisements are cool, like see the powder advertisements that enter TV... I think marriage is once in a lifetime. Then she was initially not confident so confided with her sister what her boyfriend might be fighting or something. But on the D day wow thanks to this powder, maybe subtly, she can be pretty and so confident in herself. Well I am the type of person who if it's interesting, let alone Inneke, I think it's good, I told my mother. Then I tried it." (Caca)

Nevertheless, Islamic advertisements do not necessarily lead to purchase intention. As Sari illustrates, these advertisements make Indonesian Muslims want to watch the advertisement, instead of turning it off, switching media, or distracting themselves with other activities, such as the case for other advertisements, especially ones that are considered un-Islamic. These consumers are willing to watch the full advertisement even multiple times when it shows again. 
"So, it's like that, it makes us retain, I mean it makes us want to see it more. But whether it leads to buying their products or not, I do not know. At least they get the exposure." (Sari)

In contrast, for un-Islamic advertisements, Indonesian Muslims will make efforts to not watch the advertisement. There are already negative attitudes from the un-Islamic elements of the advertisements. For example, Zahra already has negative attitudes about cigarettes as a product that is syubhat, thus she filters herself from watching cigarette advertisements. Indri also takes measures to not watch un-Islamic advertisement, especially those that are revealing the awrah or what she refers to as pornographic content. She finds it irritating and annoying that she must change the channel. So, often times when she was watching television and an un-Islamic advertisement is shown, she lowers her gaze to avoid seeing it.

"I screen cigarette advertisements as I do not like cigarettes, so I just skip them. Although they no longer show the cigarette, but most of the time, I either skip, or I do something else. I just do not watch it." (Zahra)

"It lowers my intention to buy, I do not really want to buy it, that is just it...I need to take the remote control and switch the channel, that is tiring. Haha. No, now I am more this, let us say that I do not really realise. Well, I just do not want to see it, and I would need some time to lower my head to avoid seeing it, that is annoying." (Indri)

These accounts above highlight the avoidance behaviour that some Indonesian Muslims take towards advertisements that they consider to be un-Islamic. Avoidance is one of the ways consumers resist advertising, other than contesting and empowering (Fransen, Verlegh, Kirman, \& Smit, 2015). Furthermore, when consumers are faced with offensive advertising which influences their own or others' sense of identity, the coping strategies taken are either avoidance or escape (Christy, 2003). This can be linked back to how Muslims try to maintain the purity of their faith, thus would avoid those that go against the teaching of Islam or that would cause negative effects (mudhorot). Just as how Putri explains, that she limits bad influences that may affect her way of thinking. An example she gives is the normalisation of revealing clothing that does not cover the awrah. By limiting these negative effects, she is trying to preserve her faith and the Islamic principles that she holds. 
"I am trying to limit myself from the bad things. Because at the end of the day, the bad things will give us some effects even if we are not aware, right? I mean, for example, the fashion teaches us that short pants are pretty cool, then everybody starts to think that short pants are pretty cool, which is actually untrue." (Putri)

Although Islamic advertisements do not always lead to purchases, Indonesian consumers do remember them. Thus, the brands and products that are advertised will receive the Indonesian consumers' share of mind. As Zahra described it, she will remember the brand so that one day she may refer it to a friend that upholds Islamic values.

"So, at least, if one day there is somebody who asks for reference then I would refer to that. At the time that I need to be so strict to very Islamic concepts, then I know that there is such a product. Like hotel, I know Sofyan Hotel which is Islamic... One day if there is a guest from another country who is very Islamic, then I would know oh just stay at Sofyan then." (Zahra)

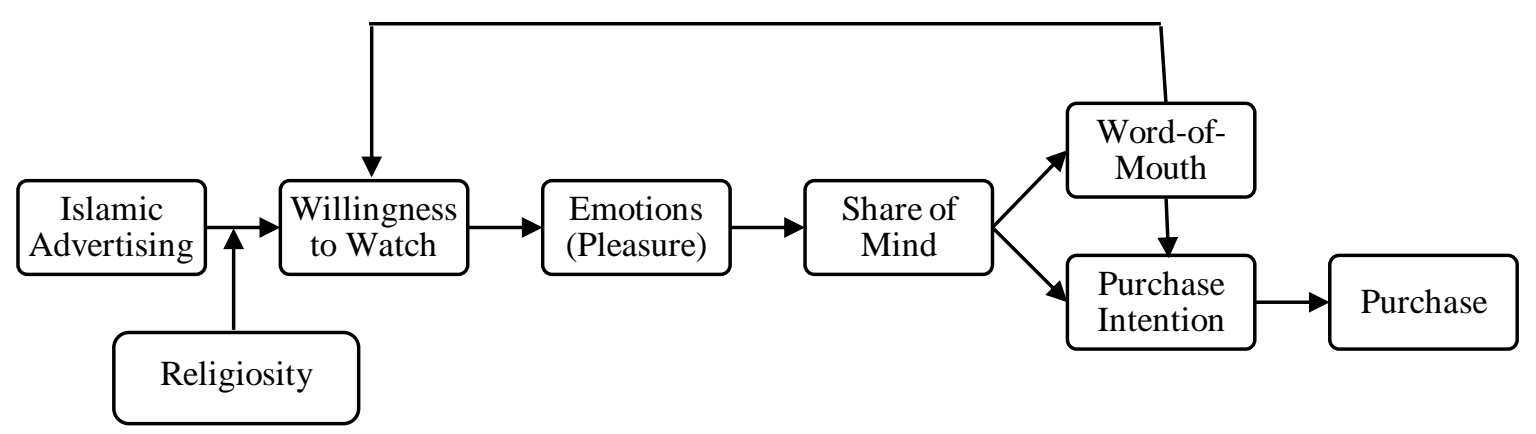

Figure 4. Effects of Islamic Advertising

Word-of-mouth (WOM) is especially important for collectivist cultures such as Indonesia. Research has also found that WOM tends to have longer carryover effects compared to traditional marketing efforts from the company (Trusov, Bucklin, \& Pauwels, 2009). WOM is often more trusted than company generated messages. Yasmin also talks about the 
importance of social media to gain WOM. Personal accounts and references are said to be more trusted. Furthermore, the number of people who support WOM is also important as the indicator of the validity of information. Here, WOM or the search for references can also be considered as part of the risk of minimising behaviour to ensure that the products they choose are suitable for them, including the halal status. Thus, WOM can eventually have a positive impact on other consumers, either leading them to engage with the advertisements or also lead to purchase intention. The effects of Islamic advertising on Indonesian Muslims have been summarised in Figure 4.

"Now, people's benchmark is social media to get some testimonials. So, people trust testimonials more than words from the company. I am also like that, like this, but I do not just believe one or two people, but how many people that say it. If there are a lot, then it is valid." (Yasmin) 


\section{Chapter 5. Conclusions and Recommendation}

\subsection{Introduction}

Increasingly, there has been special interest in researching the link between advertising and religion. This interdisciplinary focus involves the combination of well-established disciplines such as marketing, but also reaches into the discipline of Islamic studies. However, there are a limited number of studies which have looked at Muslims in other parts of the world and how their interpretation of Islam influences their perceptions of advertising. Despite having the biggest Muslim population in the world and being a dynamic emerging economy, Indonesian Muslims have rarely become the focus of research related to advertising.

This study contributed to a synthesis of existing research of the Muslim perceptions toward advertising. Although Islam does not explicitly inhibit advertising, there are several restrictions on its content. Taking into consideration that Indonesia is more moderate than other Muslim countries, this study investigated the attitude of the religious perceptions of Indonesian Muslims towards advertising.

\subsection{Conclusion of the Findings}

The following section discusses the central conclusions of this study with regard to two key research objectives and research questions. In general, the findings reveal the importance of ethics in the social context when observing the consumer perceptions of advertising. Following this, the effects of personal values and social norms in the society are investigated. Secondly, the findings demonstrate how perceptions construct consumption behaviour of the customers. Finally, the findings show the importance of ethics based on Islamic values and the principles of the advertising.

Objective: To gain a greater understanding of the perceptions of Islamic advertising to Indonesian Muslim consumers, and congruency with their identity, and effects on attitudes and behaviour

The primary objective of this research is to understand Indonesia Muslim consumers' perceptions of Islamic advertising. Accordingly, this involves exploring individual Muslims 
from different backgrounds. Various categories were used in order to obtain diversity in the observation, including gender, age range, local ethnicity and religiosity. Through exploring Islamic advertising, we have a better understanding of how consumers perceive the various meanings and associations of "Islamic" in the area of advertising. We understand not only how individual Muslim knowledge influences perceptions and consumption behaviour, but also through interactions and experiences in their social environment.

\subsubsection{Adapting to the Principles of Islamic Values}

The most fundamental feature of Islamic advertising is its compliance with the Sharia principles, which are derived from the main sources of Islamic teachings namely the Quran and Sunnah. According to Chapra (1992), these guidelines aim to ensure preservation of faith (din), life (nafs), intellect (aql), prosperity (nasl), and wealth (maal) which are also known as the essential objectives of Islamic teachings (maqasid al-shari'ah). It is designed to bring benefit and prevent harm. These would also become a moral filter in advertising activities. Hence, complying with these principles are required so that the advertisement can be accepted by Indonesian Muslim consumers.

\subsubsection{Advertising Strategies}

Overall, the findings revealed that most of the advertisements in Indonesia use hard-selling and are uninteresting for Muslims in Indonesia. They seek the advertisements that also have some form of moral message. Some consumers were stimulated by several advertisements that incorporated the substance of universal Islamic values.

However, this good initiative of spreading the messages of Islamic values was deemed to be very seasonal. Such advertisements are usually being found attached to certain Islamic moments like Ramadhan or Eid festivities. Many believe that these should also be aired all the time.

\subsection{3. "Islamic" Imaged Products, Brands, and Celebrities}

There were several products and brands identified as having an "Islamic" reputation according to Indonesian Muslims, due to their good imaging in the advertisements. 
Consequently, advertisements of these certain products and brands were automatically considered to be Islamic advertising.

The cosmetic products that placed emphasis on their halal status in their advertisements were often perceived as Islamic products. Similarly, an advertisement with the female actors wearing hijab were also often considered Islamic.

Another attribution of Islamic advertising is the use of celebrities who are deemed as pious and present a strong religious impression. These celebrities can be characterised as public figures with an Islamic image, religious preachers, and religious fictitious characters, which are specifically created for the advertisement.

\subsubsection{Culture and Religion Intertwined}

Culture and religion cannot be separated as they are both interlinked and affect each other. The two have a significant impact on global advertising practices, including that of brand images and perceptions. Some say religion has a greater affect than culture on advertising activities.

In the case of Indonesia, such relationships are more complicated given that both religion and culture tend to be negotiated and eventually combine in a unique and sometimes unforeseeable ways. The practice of Islam is sometimes coloured with more traditional customs and local wisdom, which are derived from religions that predate Islam's arrival in the area, such as Hinduism and Buddhism.

Nevertheless, there are growing trends in the religiosity of the Indonesian Muslims towards Islam in general and more are willing to adhere to a "pure" version of Islam. People are more aware of the importance of practising Islamic teachings without the influence of traditional cultural beliefs.

Notwithstanding Indonesian Muslim are growing to be more pious in purifying Islamic practices, the influence of culture cannot be neglected. Culture still plays an important role in shaping their worldview. The companies, therefore, believe that they must take into consideration the generally accepted values and norms of Indonesian society.

The foremost cultural and religious consideration needing to be considered by the companies is the issue of decency, exposure, and sex appeal. Negligence of these issues will result in bad 
perceptions towards the products as well as the companies. They have been considered as degrading the dignity of women.

In addition, some important cultural norms and values also need to be recognised. Generally, Indonesians can be categorised as Eastern culture (Irwanto, 2009). The most important characteristic of Eastern cultures is collectivism: placing great emphasis on harmony, openhandedness, respectfulness, and building solid relationship with others.

\subsubsection{The Discourse on Standardisation versus Localisation}

The interconnectedness of culture and religion also creates its own challenge that marketers have to face when producing advertisements for Indonesian Muslim consumers. On the one hand, Indonesian Muslims place strong emphasis on universal values such as family, togetherness, and helping other people. This implies that standardisation is an advertising strategy that can be optimised in Indonesia. Standardisation can especially be done in the form of pan-regional advertising.

One good example that was frequently mentioned by the respondents during the interviews was a Thai advertisement. Many of them were touched by the advertisement as it contained a moral story. Another interesting point here is that the advertisement was not available in Indonesia. The products advertised are also not being marketed in the country. The respondents accessed the advertisements through social media and they became viral as inspiring advertisements. The respondents were impressed by the advertisements and expressed a desire for similar advertisements in Indonesia.

Moreover, the Thai advertisements generate awareness and attention, as they are not just focused on trying to sell products. They are appreciated because they have a touching story, which includes a moral message.

Despite the Indonesian consumers' admiration of foreign advertisements, they also respect the use of local content and local actors in certain advertisements. It makes those advertisements more relevant to them. On the other hand, Indonesian consumers also perceived that several advertisements that were made in Indonesia are also used abroad. This escalates their appreciation of the advertisement and also instils a feeling of pride. 
More specifically, Indonesians like learning about their country's landscape and local cultures. They are proud of their natural and cultural heritage, but the diversity is still underexplored, thus Indonesians are always looking for opportunities to learn more about their rich heritage. Respondents appreciated advertisements, which included aspects of local knowledge and traditions; it helped them feel more connected with the content and product. Thus, it may increase their willingness to keep watching the advertisement instead of ignoring it.

\subsubsection{Construction of Self-images}

In a collectivist country such as Indonesia, the self is interdependent with society, and people's behaviours are also determined by societal factors including their hierarchical status. The two most interesting findings in this study surround negative and ideal images. The respondents found inauthentic and sensual images as major issues in advertising.

The negative images that were mentioned most frequently during the interviews were inauthentic images. One interesting finding is the matter of beauty. Most beauty product advertisements in Indonesia define the ideal beauty as having white and pearly skin.

However, Indonesian Muslim consumers are more aware that there is no single image of beauty. They are proud of their diversity and believe that various skin colours should also be considered in advertising. Thus, the depiction of white skin as the single definition of beauty becomes inauthentic as compared to the diversity of skin colour seen in daily life. From a cultural perspective, Forehand and Deshpandé (2001) contend this inauthentic image of beauty can also be associated with ethnic self-awareness.

Furthermore, the following category of negative images that were found is sensual images, meaning those that use sex appeal. Sensuality can be portrayed in clothing, behaviour, and language. Indonesian Muslims would find the portrayal of sensual content offensive in a variety of ways, including: disregard for the polite dress code; erotic gestures; and using strong sexual appeal.

For Indonesian Muslims, in general, the ideal images in advertising are not only seen in terms of physical appearance, but also in terms of character. Ideally, the images in advertisements are those that represent role models to become better Muslims through righteous characters 
that are in accordance with Islamic values and norms. Evidence of this comes from the occasional use of religious preachers in Islamic advertising.

\subsubsection{The Impact of Islamic Advertisements}

Islamic advertisements bring positive emotions to Indonesian Muslim consumers. Such advertisements are able to make them feel more calm and peaceful. The sense of calm arises from the experience of pleasure from watching an advertisement. This is in contrast to the irritation and offense that consumers sometimes feel towards un-Islamic advertising, as described in the prior discussion of negative images.

Islamic advertising can be seen to influence Indonesian Muslims consumers' attitudes and behaviours. Some say the advertisements of Wardah, the halal cosmetics brand which was well known for their Islamic image, left a very positive impression. This impression then translated into positive attitudes and affected behaviour in two ways. First, it led to positive recommendations through word-of-mouth regarding certain brands and products. Second, purchase intention emerged, which eventually led to purchasing.

Conversely, Indonesian Muslims will make an effort to avoid watching un-Islamic advertisements. There are negative attitudes towards this kind of advertisements. For example, negative attitudes towards advertisements of cigarettes, which is considered a syubhat product. Others prefer not to watch un-Islamic advertisements, especially those that are revealing the awrah or what is considered pornographic content.

The avoidance behaviour demonstrated by Indonesian Muslim consumers towards advertisements they consider un-Islamic is one of the manifestation from consumers to resist such advertisements. This can be seen as an effort by Muslims to maintain the purity of their faith, and therefore avoid going against the teaching of Islam or elements that would cause negative impacts (mudhorot). By limiting these negative effects, a Muslim is actually trying to preserve his/her faith and the Islamic principles that he/she holds.

\subsection{Managerial Implications}

Customer perception is of prime concern for companies. International marketers need to know about Muslims' perceptions, considerations and their ethical issues regarding 
advertising in order to become successful in countries with a significant amount of Muslim population. A case study of Pakistan concludes that an Islamic appreciation of products and services offered by companies can acquire greater acceptance in a Muslim majority country (Abbasi et al., 2011).

International marketers need to be aware of the religious perceptions of the consumers in their target country in order to become successful in marketing their products and to gain public acceptance. They must place emphasis on several sensitive ethical issues, which may make their products controversial in the eyes of the consumers and create resistance.

\subsection{Theoretical Contributions}

This study has contributed to the body of literature of Islamic advertising by providing a gist of Islamic marketing and Islamic advertising, the perceptions of these topics and the attitudes and behaviour of Indonesian Muslim consumers towards the issues. The research draws on a wide range of disciplines including marketing, sociology, psychology, and Islamic studies in order to build a wide-ranging understanding of Islamic advertising. The study has elaborated these issues by showing how culture affects individual perceptions of advertising.

\subsection{Methodological Contributions}

This study employed methodological techniques not commonly used in marketing and advertising literature. The study successfully utilised qualitative methods to consumer's perception in an Islamic advertising framework. This methodology allowed for flexibility in research design and examined the respondents' perspectives as individuals. By conducting individual interviews, the responses of each participant could be analysed to obtain general patterns of Muslim consumers in Indonesia.

Semi-structured, in-depth interviews allowed for exploration of the research questions. Other relevant topics and issues could also be elaborated on during the interviews. This interview method allowed the researcher to obtain a richer understanding of Indonesian Muslim consumer perceptions. However, there were some limitations with this approach, which future researchers should be aware of in order to improve the quality of research. 


\subsection{Limitations}

The research applied an adapted interview methodology with 25 participants. This approach enabled the research to explore the dynamics within Muslim consumers in Indonesia by conducting individual interviews. As discussed above, the adapted case study methodology is a limitation of this research but it did allow for analysis of the individuals within and between Indonesian Muslims to generate findings that were meaningful, valuable and grounded in context. These interviews have adopted a general approach by taking the opinion of the respondents about some products that were considered controversial amongst the wider Muslim Indonesian society.

\subsection{Future Directions}

The findings of this research were exploratory in nature, with the purpose of making theoretical generalisations to provide a conceptualisation of Islamic advertising; how this links to congruity with the Muslim identity; and effects on attitude and behaviour. A more focused approach could be adopted in future to assess the opinion of Muslim consumers regarding specific advertisements instead of relying on personal memories of such advertisements. 


\section{References}

Abdullah, K. (2008). Marketing mix from an Islamic perspective (1 ed.). London: Pearson Prentic Hall.

Abdullah, K., \& Ahmad, M. I. (2010). Compliance to Islamic marketing practices among businesses in Malaysia. Journal of Islamic Marketing, 1(3), 286-297. doi:http://dx.doi.org/10.1108/17590831011082446

Abdullah, Z. (2008). Negotiating identities: a history of Islamization in black West Africa. Journal of Islamic Law and Culture, 10(1), 5-18.

Abuznaid, S. (2012). Islamic marketing: Addressing the Muslim market. An - Najah University Journal of Research (Humanities), 26(6), 1473-1503.

Aji, H. M. (2017). Does skepticism toward halal label exist? The empirical evidence from Indonesia. Paper presented at the 8th Global Islamic Marketing Conference, Alanya, Turkey.

Alden, D. L., Steenkamp, J.-B. E., \& Batra, R. (1999). Brand positioning through advertising in Asia, North America, and Europe: The role of global consumer culture. The Journal of Marketing, 75-87.

Ali, A. J. (2011). Islamic ethics and marketing. In Ö. Sandikci \& G. Rice (Eds.), Handbook of Islamic marketing (pp. 17-34). Cheltenham: Edward Elgar Publishing.

Ali, A. J., \& Al-aali, A. (2015). Marketing and ethics: What Islamic ethics have contributed and the challenges ahead. Journal of Business Ethics, 129(4), 833-845. doi:http://dx.doi.org/10.1007/s10551-014-2131-x

Ali, A. J., \& Gibbs, M. (1998). Foundation of business ethics in contemporary religious thought: The Ten Commandment perspective. International Journal of Social Economics, 25(10), 1552-1564.

Ali, M. Y. (2016). An Islamic model of marketing ethics. In A. Jafari \& Ö. Sandikci (Eds.), Islam, Marketing and Consumption: Critical Perspectives on the Intersections (pp. 141-155). Abingdon: Routledge.

Ali, Y., \& Khan, G. (2014). The Islamic market: The key challenges to effective marketing. In J. Sinnakkannu, M. Nair, \& G. Lee (Eds.), Islamic Business: Contemporary Issues and Economic Development (pp. 197-227). Kuala Lumpur: LexisNexis.

An, D. (2007). Advertising visuals in global brands' local websites: a six-country comparison. International Journal of Advertising, 26(3), 303-332.

Anatariona, R. (2014). Analisis pengaruh efektivitas iklan televisi dan keunggulan produk terhadap minat beli sabun mandi Lux. Universitas Diponegoro, Semarang.

Anjani, R. (2015, 2 September). Dian Pelangi hingga Wulan Guritno jadi model koleksi terbaru Charriol. Detik.

Arham, M. (2010). Islamic perspectives on marketing. Journal of Islamic Marketing, 1(2), 149-164.

Ariffin, S. K., Ismail, I., \& Shah, K. A. M. (2016). Religiosity moderates the relationship between ego-defensive function and attitude towards advertising. Journal of Islamic Marketing, 7(1), 15-36. doi:10.1108/JIMA-11-2014-0074

Armstrong, J. S. (2011). Evidence-based advertising: An application to persuasion. International Journal of Advertising, 30(5), 743-767.

Badr, H. (2004). Islamic identity re-covered: Muslim women after September 11th. Culture and Religion, 5(3), 321-338.

Bailey, J. M., \& Sood, J. (1993). The effects of religious affiliation on consumer behavior: A preliminary investigation. Journal of Managerial Issues, 5(3), 328-352.

Bari, A., \& Abbas, R. Z. (2011). Advertisement \& Islam: A muslim world perspective. Australian Journal of Business and Management Research, 1(6), 152-157. 
Beatty, S. E., \& Smith, S. M. (1987). External search effort: An investigation across several product categories. Journal of Consumer Research, 14(1), 83-95.

Belch, G. E. (1978). Belief systems and the differential role of the self-concept. NA-Advances in Consumer Research, 5, 320-325.

Belch, G. E., \& Landon Jr, E. L. (1977). Discriminant validity of a product-anchored selfconcept measure. Journal of Marketing Research, 14(2), 252-256.

Belfrage, C., \& Hauf, F. (2016). The Gentle Art of Retroduction: Critical Realism, Cultural Political Economy and Critical Grounded Theory. Organization Studies, 38(2), 251271. doi:10.1177/0170840616663239

Bhaskar, R. (1978). The Possibility of Naturalism. Sussex: Harvester Press.

Bhaskar, R. (1998). Philosophy and scientific realism. In M. S. Archer, R. Bhaskar, A. Collier, T. Lawson, \& A. Norrie (Eds.), Critical realism: Essential readings (pp. 1647). London: Routledge.

Blackwell, R. D., Miniard, P. W., \& Engel, J. F. (2003). Consumer behaviour. Orlando, FL: Harcourt.

Boush, D. M., Friestad, M., \& Rose, G. M. (1994). Adolescent skepticism toward TV advertising and knowledge of advertiser tactics. Journal of Consumer Research, $21(1), 165-175$.

BPOM. (2013). Main Function of NA-DFC. Retrieved from http://www.pom.go.id/new/index.php/view/fungsi

Brenner, S. (1996). Reconstructing Self and Society: Javanese Muslim Women and "The Veil". American Ethnologist, 23(4), 673-697.

Burns, R. B. (1979). The self concept: In theory, measurement, development and behaviour. London: Longman

Buzzell, R. D. (1968). Can you standardize multinational marketing? Harvard Business Review, 46(6), 102-113.

Cader, A. A. (2015). Islamic challenges to advertising: a Saudi Arabian perspective. Journal of Islamic Marketing, 6(2), 166-187.

Center, P. R. (2015). The future of world religions: Population growth projections 20102050. Retrieved from http://www.pewforum.org/2015/04/02/religious-projections2010-2050/

Chapra, M. U. (1992). Islam and the economic challenge. Herndon, VA: International Institute of Islamic Thought (IIIT).

Cheong, Y., Kim, K., \& Zheng, L. (2010). Advertising appeals as a reflection of culture: a cross-cultural analysis of food advertising appeals in China and the US. Asian Journal of Communication, 20(1), 1-16.

Christy, T. P. (2003). A qualitative study of consumer reactions to offensive advertising. The University of Tennessee, Knoxville.

Church, A. T., Katigbak, M. S., Del Prado, A. M., Ortiz, F. A., Mastor, K. A., Harumi, Y., . . . White, F. A. (2006). Implicit theories and self-perceptions of traitedness across cultures: Toward integration of cultural and trait psychology perspectives. Journal of Cross-Cultural Psychology, 37(6), 694-716.

Cook, T. D., \& Campbell, D. T. (1979). Quasi-experimentation: Design and analysis for field settings. Chicago: Rand McNally.

Corbetta, P. (2003). Social research: Theory, methods and techniques. London: Sage.

Creswell, J. W. (1994). Research design: Quantitative and qualitative approaches. Thousand Oakes: Sage Publication.

Creswell, J. W. (2013). Qualitative inquiry and research design: Choosing among five approaches. Thousand Oaks, CA: Sage Publications. 
Crotty, M. (1998). The foundations of social research: Meaning and perspective in the research process: Sage.

De Mooij, M., \& Hofstede, G. (2010). The Hofstede model: Applications to global branding and advertising strategy and research. International Journal of Advertising, 29(1), 85110.

De Run, E. C., Butt, M. M., Fam, K.-S., \& Jong, H. Y. (2010). Attitudes towards offensive advertising: Malaysian Muslims' views. Journal of Islamic Marketing, 1(1), 25-36.

Delener, N. (1994). Religious contrasts in consumer decision behaviour patterns: their dimensions and marketing implications. European Journal of Marketing, 28(5), 3653.

Della Porta, D., \& Keating, M. (2008). How many approaches in the social sciences? An epistemological introduction. In D. Della Porta \& M. Keating (Eds.), Approaches and Methodologies in the Social Sciences (pp. 19-39). New York: Cambridge University Press.

Delozier, W., \& Tillman, R. (1972). Self-image concepts-can they be used to design marketing programs. Southern Journal of Business, 7(1), 9-15.

Dittmar, H., \& Drury, J. (2000). Self-image-is it in the bag? A qualitative comparison between "ordinary" and "excessive" consumers. Journal of Economic Psychology, 21(2), 109-142.

Dolich, I. J. (1969). Congruence relationships between self images and product brands. Journal of Marketing Research, 80-84.

Driessen, M. D. (2014). Religion and Democratization: Framing Religious and Political Identities in Muslim and Catholic Societies: Oxford University Press.

El-Bassiouny, N. (2014). The one-billion-plus marginalization: Toward a scholarly understanding of Islamic consumers. Journal of Business Research, 67(2), 42-49.

El-Bassiouny, N. (2016). Where is "Islamic marketing" heading?: A commentary on Jafari and Sandikci's (2015) "Islamic" consumers, markets, and marketing. Journal of Business Research, 69(2), 569.

Elinder, E. (1965). How international can European advertising be? The Journal of Marketing, 7-11.

Euromonitor. (2017). Advertising in Indonesia: ISIC 743. Retrieved from http://www.euromonitor.com/advertising-in-indonesia-isic-743/report

Fachruddin, F. (2006). Agama dan pendidikan demokrasi: pengalaman Muhammadiyah dan Nahdlatul Ulama: Pustaka Alvabet.

Fairclough, N. (2009). A dialectical-relational approach to critical discourse analysis in social research. In R. Wodak \& M. Meyer (Eds.), Methods of critical discourse analysis (Vol. 2, pp. 162-187). London: SAGE Publications.

Fam, K. S., Waller, D. S., \& Erdogan, B. Z. (2004). The influence of religion on attitudes towards the advertising of controversial products. European Journal of Marketing, 38(5-1), 537-555.

Farah, M. F., \& El Samad, L. (2014). The effects of religion and religiosity on advertisement assessment among Lebanese consumers. Journal of International Consumer Marketing, 26(4), 344-369.

Fatt, A. C. (1967). The danger of" local" international advertising. The Journal of Marketing, $60-62$.

Forehand, M. R., \& Deshpandé, R. (2001). What we see makes us who we are: Priming ethnic self-awareness and advertising response. Journal of Marketing Research, 38(3), 336-348.

Fransen, M. L., Verlegh, P. W. J., Kirman, A., \& Smit, E. G. (2015). A typology of consumer strategies for resisting advertising, and a review of mechanisms for countering them. 
International Journal of Advertising, 34(1), 6-16. doi:10.1080/02650487.2014.995284

Friestad, M., \& Wright, P. (1994). The persuasion knowledge model: How people cope with persuasion attempts. Journal of Consumer Research, 21(1), 1-31.

Ger, G. (2013). Islamic marketing at the Nexus of global markets-religions-politics and implications for research. Marketing Theory, 13(4), 497-503. doi: $10.1177 / 1470593113499702$

Gibbs, P., \& Ilkan, M. (2008). The ethics of marketing in Islamic and Christian communities: Insights for global marketing. Cross Cultural Management: An International Journal, 15(2), 162-175.

Guba, E. G., \& Lincoln, Y. S. (2004). Competing paradigms in qualitative research: Theories and issues. In S. N. Hesse-Biber \& P. Leavy (Eds.), Approaches to qualitative research: A reader on theory and practice. New York: Oxford University Press.

Guest, G., Bunce, A., \& Johnson, L. (2006). How many interviews are enough? An experiment with data saturation and variability. Field methods, 18(1), 59-82.

Han, S.-P., \& Shavitt, S. (1994). Persuasion and culture: Advertising appeals in individualistic and collectivistic societies. Journal of experimental social psychology, 30(4), 326-350.

Hanafi, A., \& Sallam, H. (1988). Business ethics: an Islamic perspective. Paper presented at the Seminar on Islamic Principles of Organizational Behavior Herndon, VA.

Hanafy, A. A., \& Sallam, H. (2001). Business ethics: An Islamic perspective. In A. M. Sadeq \& K. Ahmad (Eds.), Ethics in business and management: Islamic and mainstream approaches (pp. 169-187). Subang Jaya: Asean Academic Press.

Hannum, K. M. (2007). Social identity: Knowing yourself, knowing others. Greensboro, NC: Center for Creative Leadership.

Haque, A., Ahmed, K., \& Jahan, S. I. (2010). Shariah observation: advertising practices of Bank Muamalat in Malaysia. Journal of Islamic Marketing, 1(1), 70-77.

Hassan, A., Chachi, A., \& Latiff, S. A. (2008). Islamic marketing ethics and its impact on customer satisfaction in the Islamic banking industry. Journal of King Abdul Aziz University Islamic Economics, 21(1), 27-46.

Hawkins, D., Coney, K., Best, R., \& Hawkins, D. (2003). Consumer behavior: Building marketing strategy. Chicago, IL: Irwin.

Healy, M., \& Perry, C. (2000). Comprehensive criteria to judge validity and reliability of qualitative research within the realism paradigm. Qualitative market research: An international journal, 3(3), 118-126.

Hefner, R. W. (2011). Civil Islam: Muslims and democratization in Indonesia. New Jersey: Princeton University Press.

Hofstede, G., \& Hofstede, G. J. (2005). Cultures and organizations: Software of the mind (Vol. 2). New York: McGraw-Hill USA.

Hong, J. W., \& Zinkhan, G. M. (1995). Self-concept and advertising effectiveness: The influence of congruency, conspicuousness, and response mode. Psychology \& Marketing, 12(1), 53-77.

Hussin, R., Yusoff, S. H., \& Yusof, S. N. M. (2015). Islamic Representation in Television Advertising and its Impact on Modern Malay Muslim Women. Procedia-Social and Behavioral Sciences, 211, 890-895.

Ishadi, S. (2011). Negotiating Mass Media Interests and Heterogeneous Muslim Audiences in the Contemporary Social-Political Environment of Indonesia Islam and Popular Culture in Indonesia and Malaysia (pp. 21-45).

Jafari, A., \& Süerdem, A. (2012). An analysis of material consumption culture in the Muslim world. Marketing Theory, 12(1), 61-79. 
Jones, C. (2016). Images of desire. In A. Jafari \& Ö. Sandikci (Eds.), Islam, Marketing and Consumption: Critical Perspectives on the Intersections (pp. 102-122). Abingdon: Routledge.

Kadirov, D. (2014). Islamic marketing as macromarketing. Journal of Islamic Marketing, 5(1), 2-19. doi:10.1108/jima-09-2012-0054

Keenan, K. L., \& Yeni, S. (2003). Ramadan advertising in Egypt: A content analysis with elaboration on select items. Journal of Media and Religion, 2(2), 109-117.

Krauss, S. E. (2005). Research paradigms and meaning making: A primer. The qualitative report, 10(4), 758-770.

Kuhn, T. S. (1962). The structure of scientific revolutions. Chicago: The University of Chicago Press.

Kuran, T. (1995). Islamic economics and the Islamic subeconomy. The Journal of Economic Perspectives, 9(4), 155-173.

Layder, D. (1990). The realist image in social science. London: The Macmillan Press.

Lee, M., \& Johnson, C. (2013). Principles of advertising: a global perspective: Routledge.

Levitt, T. (1983). The globalization of markets. Harvard Business Review, 61(3), 92-102.

Lofland, J., \& Lofland, L. H. (2006). Analyzing social settings. Belmont, CA: Wadsworth Publishing Company.

Lutz, R. J., \& Reilly, P. J. (1974). An exploration of the effects of perceived social and performance risk on consumer information acquisition. NA-Advances in Consumer Research, 1, 393-405.

Maheshwari, A. K. (1974). Self-product image congruence: A macro-level analysis. Ann Arbor, MI: University Microfilms International.

Massey, G. R., Waller, D. S., Wang, P. Z., \& Lanasier, E. V. (2013). Marketing to different Asian communities: The importance of culture for framing advertising messages, and for purchase intent. Asia Pacific Journal of Marketing and Logistics, 25(1), 8-33.

Mehrabian, A., \& Russell, J. A. (1974). The basic emotional impact of environments. Perceptual and motor skills, 38(1), 283-301.

Midgley, D. F. (1983). Patterns of interpersonal information seeking for the purchase of a symbolic product. Journal of Marketing Research, 20, 74-83.

Miracle, G. E. (1987). Feel-do-learn: An alternative sequence underlying Japanese consumer response to television commercials. Paper presented at the The 1987 Conference of the American Academy of Advertising, Columbia, SC.

Mokhlis, S. (2009). Religious differences in some selected aspects of consumer behavior: a Malaysian study. The Journal of International Management Studies, 4(1), 67-76.

Mokhtar, A., \& Samsudin, S. (2015). Islam and advertising: The ideal stakeholder perspective. Paper presented at the The 1st International Conference on Innovative Communication and Sustainable Development in ASEAN, Bangkok.

Moon, Y. S., \& Chan, K. (2005). Advertising appeals and cultural values in television commercialsA comparison of Hong Kong and Korea. International Marketing Review, 22(1), 48-66.

Mueller, B. (1987). Reflections of culture: An analysis of Japanese and American advertising appeals. Journal of Advertising Research, 27(3), 51-59.

Muhamad, R. (2009). Religiosity, Ethical Judgement and Malaysian Muslim Students. Journal of Business Systems, Governance and Ethics, 4(1), 53.

MUI. (2015, 19 January). Menyoal iklan produk halal. Retrieved from http://www.halalmui.org/mui14/index.php/main/detil_page/48/2271

MUI, L. (2014). Sertifikat Halal MUI. Retrieved from http://www.halalmui.org/muil4/index.php/main/go_to_section/55/1360/page/1

Murphy, P. E. (2010). Ethics of Marketing. Wiley Encyclopedia of Management, 2, 83-98. 
Muslimdaily. (2014, 22 June). Meskipun 0\% alkohol, Bintang Zero tetap minuman haram. Retrieved from http://www.muslimdaily.net/khazanah-islam/wawasanislam/meskipun-0-alkohol-bintang-zero-tetaplah-minuman-haram.html

NahiMunkar. (2013, 10 May). Anda tahu iklan-iklan yang tidak sesuai dengan Islam? Beri peringatan ke Ummat Islam lewat nahimunkar.com.

Nan, X., \& Faber, R. J. (2004). Advertising theory: Reconceptualizing the building blocks. Marketing Theory, 4(1-2), 7-30.

Nanji, A. (1991). Islamic ethics. In P. Singer (Ed.), A Companion of Ethics (pp. 106-118). Oxford: Blackwells.

Naseri, A., \& Tamam, E. (2012). Impact of Islamic religious symbol in producing favorable attitude toward advertisement. The Public Administration and Social Policies Review, 1(8), 61-77.

Nestorović, Č. (2016). Islamic Marketing: Understanding the Socio-Economic, Cultural, and Politico-Legal Environment. Basel: Springer International Publishing AG.

Nooh, M. N. (2009). A qualitative insight into Islamic advertising ethics. Paper presented at the 1st Global Conference Ethics in Public Life, Salzburg. http://www.interdisciplinary.net/wp-content/uploads/2009/02/nooh-paper.pdf

O’Guinn, T. C., Allen, C. T., \& Semenik, R. J. (2000). Advertising (Vol. 2). Cincinnati, OH: South Western.

OgilvyNoor. (2010). Brands, Islam and the new Muslim consumer. Retrieved from http://www.ogilvy.com/News/Press-Releases/May-2010-The-Global-Rise-of-theNew-Muslim-Consumer.aspx

Okazaki, S., Mueller, B., \& Taylor, C. R. (2010). Measuring soft-sell versus hard-sell advertising appeals. Journal of Advertising, 39(2), 5-20.

Okazaki, S., Taylor, C. R., \& Zou, S. (2006). Advertising standardization's positive impact on the bottom line: a model of when and how standardization improves financial and strategic performance. Journal of Advertising, 35(3), 17-33.

Onkvisit, S., \& Shaw, J. (1987). Self-concept and image congruence: Some research and managerial implications. Journal of Consumer Marketing, 4(1), 13-23.

Osgood, C. E., \& Tannenbaum, P. H. (1955). The principle of congruity in the prediction of attitude change. Psychological review, 62(1), 42.

Permana, F. E. (2016, 27 December). Stasiun TV Islam tawarkan tayangan yang lebih baik. Republika. Retrieved from http://www.republika.co.id/berita/dunia-islam/islamnusantara/16/12/27/oiu7j9396-stasiun-tv-islam-tawarkan-tayangan-yang-lebih-baik

Perry, M., \& Hamm, B. C. (1969). Canonical analysis of relations between socioeconomic risk and personal influence in purchase decisions. Journal of Marketing Research, 6, 351-354.

Polyorat, K., Alden, D. L., \& Alden, D. L. (2005). Self-construal and need-for-cognition effects on brand attitudes and purchase intentions in response to comparative advertising in Thailand and the United States. Journal of Advertising, 34(1), 37-48.

Purnama, F. A., \& Safira, A. (2017). Investigating Islamic advertising ethics: Perceptions of Indonesian Muslims. Journal of Emerging Economies and Islamic Research, 5(2), 4357.

Putri, M. (2014, 4 February). Cara Bunga Citra Lestari Bangkitkan Getaran Cinta. Berita Satu. Retrieved from http://www.beritasatu.com/cinta/164511-cara-bunga-citralestari-bangkitkan-getaran-cinta.html

Qadafi, A. M., \& Wahyudi, R. (2014). Advertising language: A pragmatic approach to cigarette advertisement in Indonesia. Issues in Language Studies, 3(1), 1-14.

Qur'an: Oxford World Classic edition. (2005). (M. A. S. A. Haleem, Trans.). Oxford: Oxford University Press. 
Qutb, M. (1997). Bhrantir Berajale Islam (Islam The Misunderstood Religion) (A. Razzak, Trans.). Dhaka: Adhunik Prokashani.

Renzetti, C. M., \& Curran, D. J. (1998). Living Sociology. Boston: Allyn \& Bacon.

Reuters, T., \& Standard, D. (2016). State of the Global Islamic Economy 2016/17. Thomson Reuters and Dinar Standard, New York City.

Rice, G., \& Al-Mossawi, M. (2002). The implications of Islam for advertising messages: The Middle Eastern context. Journal of Euromarketing, 11(3), 71-96.

Richards, J. I., \& Curran, C. M. (2002). Oracles on "advertising": Searching for a definition. Journal of Advertising, 31(2), 63-77.

Riduwan, F. (2013). Makna jilbab bagi komunitas Hijabers Surabaya. UIN Sunan Ampel Surabaya, Surabaya.

Rosenberg, M. (1979). Conceiving the self. New York: Basic Books.

Roth, M. S. (1995). Effects of global market conditions on brand image customization and brand performance. Journal of Advertising, 24(4), 55-75.

Rubin, H. J., \& Rubin, I., S. (1995). Qualitative Interviewing: The Art of Hearing Data. Thousand Oaks, CA: Sage.

Ruhiyan, Y. (2016, 12 July). Sambut idul fitri, Bukalapak luncurkan web series Youtube Medok pendekar jari sakti. Tribun News. Retrieved from http://www.tribunnews.com/nasional/2016/07/12/sambut-idul-fitri-bukalapakluncurkan-web-series-youtube-medok-pendekar-jari-sakti

Saeed, A. (1999). Towards religious tolerance through reform in Islamic education: The case of the state institute of Islamic studies of Indonesia. Indonesia and the Malay World, 27(79), 177-191.

Saeed, M., Ahmed, Z. U., \& Mukhtar, S.-M. (2001). International marketing ethics from an Islamic perspective: a value-maximization approach. Journal of Business Ethics, 32(2), 127-142.

Saeed, M., \& Baig, A. K. (2013). Islamic Shari'ah-compliant marketing. International Journal of Social Entrepreneurship and Innovation 2, 2(2), 166-178.

Sally, U. (2015). from https://twitter.com/UkhtiSally/status/661140676017438720/photo/1

Samsudin, S., \& Mahmud, M. (2013). Ikhtilat dan tabarruj: kajian terhadap prinsip dan disiplin surah al-Nur dan al-Ahzab. In A. M. Yusoff (Ed.), Quran: Surging the Ummah transformation. Negeri Sembilan: Universiti Sains Islam Malaysia.

Sand1kçı, Ö. (2011). Researching Islamic marketing: past and future perspectives. Journal of Islamic Marketing, 2(3), 246-258.

Sandikçi, Ö., \& Ger, G. (2011). Islam, Consumption and Marketing: Going Beyond the Essentialist Approaches. In Ö. Sandıç̧ı \& G. Rice (Eds.), Handbook of Islamic marketing (pp. 484-501). Cheltenham: Edward Elgar.

Sandikçi, Ö., \& Jafari, A. (2013). Islamic encounters in consumption and marketing. Marketing Theory, 13(4), 411-420.

Sandikçi, Ö., \& Rice, G. (2011). Handbook of Islamic marketing. Cheltenham: Edward Elgar Publishing.

Saraswati, L. A. (2010). Cosmopolitan whiteness: The effects and affects of skin-whitening advertisements in a transnational women's magazine in Indonesia. Meridians: feminism, race, transnationalism, 10(2), 15-41.

Sari, I. K. (2016, 2 February). Heboh kerudung halal Zoya, ini reaksi para netizen Detik. Retrieved from https://wolipop.detik.com/read/2016/02/03/141541/3133869/1632/heboh-kerudunghalal-zoya-ini-reaksi-para-netizen

Sariayu. (2015). Sariayu Hijab Series. Retrieved from http://www.sariayu.com/hijab-series/ 
Sayer, A. (2000). Realism and social science. London: Sage Publications.

Sayer, A. (2004). Why critical realism? In S. Ackroyd \& S. Fleetwood (Eds.), Critical realist applications in organisation and management studies (pp. 6-20). London: Routledge.

Schramm, W. (1973). Men, messages, and media: A look at human communication. New York: Harper \& Row.

Shirazi, F. (2016). Brand Islam: The Marketing and Commodification of Piety. Austin, TX: University of Texas Press.

Sirgy, M. J. (1980). The self-concept in relation to product preference and purchase intention. Developments in Marketing Science, 3(5), 350-354.

Smaoui, F., \& Ghariani, G. (2011). Being fashionable in today's Tunisia: What about cultural identity? In Ö. Sandikci \& G. Rice (Eds.), Handbook of Islamic marketing (pp. 97113). Cheltenham: Edward Elgar Publishing.

Stayman, D. M., \& Deshpande, R. (1989). Situational ethnicity and consumer behavior. Journal of Consumer Research, 16(3), 361-371.

Sudibyo, A. P. (2013). Pengaruh Penggunaan Mamah Dedeh sebagai Endorser terhadap Citra Merek Produk Larutan Cap Kaki Tiga. Jurnal Ilmiah Universitas Bakrie, 2(01).

Sugiantoro, A. (2017). The role of Indonesian Ulema Council on halal certification postissuance of Law No. 33 of 2014. Journal of Education and Social Sciences, Vol. 6 (February).

Trusov, M., Bucklin, R. E., \& Pauwels, K. (2009). Effects of word-of-mouth versus traditional marketing: findings from an internet social networking site. Journal of marketing, 73(5), 90-102.

Turnbull, S., Howe-Walsh, L., \& Boulanouar, A. (2016). The advertising standardisation debate revisited: Implications of Islamic ethics on standardisation/localisation of advertising in Middle East Islamic States. Journal of Islamic Marketing, 7(1), 2-14. doi:10.1108/JIMA-11-2014-0072

Uddin, S. J. (2003). Understanding the framework of business in Islam in an era of globalization: a review. Business ethics: a european review, 12(1), 23-32.

Van Raaij, W. F. (1997). Globalisation of marketing communication? Journal of Economic Psychology, 18(2), 259-270.

Vatikiotis, M. R. (1993). Indonesian politics under Suharto: order, development and pressure for change: Routledge London and New York.

Volkoff, O., Strong, D. M., \& Elmes, M. B. (2007). Technological embeddedness and organizational change. Organization Science, 18(5), 832-848.

Waller, D. S., \& Fam, K. S. (2000). Cultural values and advertising in Malaysia: views from the industry. Asia Pacific Journal of Marketing and Logistics, 12(1), 3-16.

Wanandi, J. (2002). Islam in Indonesia: Its history, development and future challenges. Asia Pacific Review, 9(2), 104-112.

Wells, W., Burnett, J., \& Moriarty, S. (1998). Advertising Principles and Practices (Vol. 4). Upper Saddle River, NJ: Prentice Hall.

Wilkinson, M. L. N. (2013). Introducing Islamic Critical Realism: A Philosophy for Underlabouring Contemporary Islam. Journal of Critical Realism, 12(4), 419-442. doi:10.1179/1476743013Z.00000000014

Wilson, J. A. J. (2014). The halal phenomenon: An extension or a new paradigm? Social Business, 4(3), 255-271.

Wilson, J. A. J., Belk, R. W., Gary, J. B., Özlem, S., Hermawan, K., Sobh, R., . . Scott, L. (2013). Crescent marketing, Muslim geographies and brand Islam. Journal of Islamic Marketing, 4(1), 22-50. doi:http://dx.doi.org/10.1108/17590831311306336 
Wilson, J. A. J., \& Grant, J. (2013). Islamic marketing - a challenger to the classical marketing canon? Journal of Islamic Marketing, 4(1), 7-21. doi: $10.1108 / 17590831311306327$

Wilson, J. A. J., \& Liu, J. (2010). Shaping the Halal into a brand? Journal of Islamic Marketing, 1(2), 107-123. doi:10.1108/17590831011055851

Wilson, J. A. J., \& Liu, J. (2011). The challenges of Islamic branding: navigating emotions and halal. Journal of Islamic Marketing, 2(1), 28-42.

Wind, Y. (1986). The myth of globalization. Journal of Consumer Marketing, 3(2), 23 - 26.

Wira, N. N. (2016, 3 June). Google announces most popular YouTube video ads. The Jakarta Post. Retrieved from http://www.thejakartapost.com/life/2016/06/03/googleannounces-most-popular-youtube-video-ads.html

Wolcott, H. F. (1990). On seeking-and rejecting-validity in qualitative research In E. Eisner \& A. Peshkin (Eds.), Qualititative inquiry in education the coutinuing debate (pp. 121-152). New York: Teachers College Press.

Yip, G. (1995). The Global Strategy: Managing For Worldwide Competitive Advantage. Upper Saddle River, NJ: Prentice Hall Incorporation.

Yulianti, T. E. (2016, 9 February). Zoya minta maaf soal heboh kerudung halal. Detik. Retrieved from https://wolipop.detik.com/read/2016/02/09/183102/3137948/1632/zoya-minta-maafsoal-heboh-kerudung-halal

Zachariadis, M., Scott, S. V., \& Barrett, M. I. (2013). Methodological Implications of Critical Realism for Mixed-Methods Research. MIS quarterly, 37(3), 855-879.

Zarrad, H., \& Debabi, M. (2015). Islamic marketing ethics: A literature review. International Journal of Management Research and Reviews, 5(2), 60-66.

Zhang, J. (2010). The persuasiveness of individualistic and collectivistic advertising appeals among Chinese generation-X consumers. Journal of Advertising, 39(3), 69-80. 


\section{Appendix}

Appendix 1. Participant Information Sheet (English)

\section{VICTORIA UNIVERSITY OF WELLINGTON Te Whare Wānanga o te Ūpoko o te Ika a Māui}

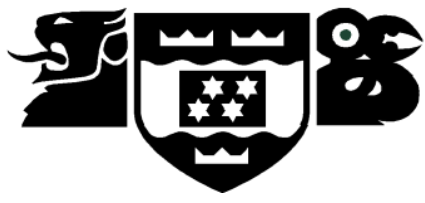

School of Marketing and International Business

\section{Perceptions of Islamic Advertising Held By Indonesian Muslims \\ Student Researcher's Name: Anya Safira}

Thank you for showing an interest in this project. Please read this information sheet carefully before deciding whether or not to participate. If you do decide to participate, thank you. If you decide not to take part, thank you for considering my request.

\section{WHAT IS THE PURPOSE OF THIS PROJECT?}

The research is a part of my Masters degree in marketing at Victoria University of Wellington. This research aims to gain a greater understanding of the perceptions of Islamic advertising held by Indonesian Muslim consumers and how these perceptions are shaped. This research has been reviewed and approved by the Victoria University of Wellington Pipitea Human Ethics Committee (No. 23266).

\section{WHAT WILL YOUR ROLE AND RESPONSIBILITIES BE IF YOU TAKE PART?}

Participation from you would involve being interviewed by me once in a public setting, such as a café. The audio-recorded interview would take approximately 60 minutes but will only begin with your consent, and it can be terminated at any time, without providing reasons. You 
can withdraw from the study up to seven days after the interview, and any data provided by you will be destroyed or returned to you.

\section{WHAT WILL HAPPEN TO THE INFORMATION YOU GIVE?}

This research is completely confidential. Your name will not be used in the resulting report, a pseudonym will be used instead, and any information traceable to you will be excluded from every analysis. Identifying demographic information such as age and gender may be included to support the analysis. The raw data will be reviewed by me and my supervisor and your name will be changed before the supervisors review the raw data. The interview transcripts, summaries and digital recordings will be securely stored in password protected files and destroyed 5 years after the conclusion of the research.

\section{WHAT WILL THE OUTPUTS OF THIS PROJECT BE?}

Information will only be reported in an aggregated/non-attributable form as part of my Masters report. Summary results of this investigation may be published in academic or professional journals and/ or presented at professional or academic conferences. The collected data may also be used for further research, such as a Doctorate dissertation. You can be reassured that your name will be kept confidential, and that any information or opinions that could be traceable to you will not be reported.

\section{IF YOU HAVE ANY QUESTIONS OR PROBLEMS, WHO CAN YOU CONTACT?}

For ethics enquiries: AProf Susan Corbett, email susan.corbett@vuw.ac.nz, telephone +64-4463 5480). For all other enquiries contact:

\section{STUDENT:}

Name: Anya Safira

University email address:

safiraanya@myvuw.ac.nz
Supervisor:

Prof. Kim Fam

Lecturer

School of Marketing \& International Business

044636459

kim.fam@vuw.ac.nz 
Appendix 2. Participant Information Sheet (Indonesian)

VICTORIA UNIVERSITY OF WELLINGTON

Te Whare Wānanga o te Ūpoko o te Ika a Māui

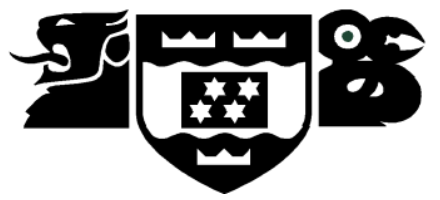

School of Marketing and International Business

\title{
Persepsi Muslim Indonesia terhadap Iklan yang Islami
}

\author{
Nama Mahasiswa Peneliti: Anya Safira
}

Terima kasih untuk minat Anda dalam proyek ini. Silakan baca lembar informasi ini dengan seksama sebelum memutuskan apakah akan berpartisipasi atau tidak. Jika Anda memutuskan untuk berpartisipasi, terima kasih. Jika Anda memutuskan untuk tidak ambil bagian, terima kasih karena telah mempertimbangkan permintaan saya.

\section{APAKAH TUJUAN DARI PROYEK INI?}

Penelitian ini merupakan bagian dari gelar Magister saya di bidang pemasaran di Victoria University of Wellington. Penelitian ini bertujuan untuk mendapatkan pemahaman yang lebih jauh tentang persepsi konsumen Muslim Indonesia terhadap iklan yang Islami dan bagaimana persepsi tersebut terbentuk. Penelitian ini telah ditinjau dan disetujui oleh Komite Etika Manusia Pipitea di Victoria University of Wellington (No. 23266).

\section{APAKAH YANG AKAN MENJADI PERAN DAN TANGGUNG JAWAB ANDA JIKA BERPARTISIPASI?}

Partisipasi Anda akan melibatkan satu kali wawancara oleh saya dalam ruang publik, seperti kafe. Wawancara audio yang direkam akan menghabiskan waktu sekitar 60 menit tetapi hanya akan dimulai dengan persetujuan Anda, dan dapat dihentikan setiap saat, tanpa harus memberikan alasan. Anda dapat menarik diri dari penelitian sampai tujuh hari setelah 
wawancara, dan data yang Anda disediakan akan dihancukan atau dikembalikan kepada Anda.

\section{APAKAH YANG AKAN TERJADI PADA INFORMASI YANG ANDA BERIKAN?}

Penelitian ini benar-benar rahasia. Nama Anda tidak akan digunakan dalam laporan yang dihasilkan, nama samaran akan digunakan sebagai penggantinya, dan informasi yang dapat digunakan untuk melacak Anda akan dikeluarkan dari setiap analisis. Informasi demografis seperti usia dan jenis kelamin mungkin dimasukkan untuk mendukung analisis. Data mentah akan ditinjau oleh saya dan pembimbing saya, dan nama Anda akan diubah sebelum pembimbing meninjau data mentah tersebut. Transkrip wawancara, ringkasan dan rekaman digital akan disimpan secara aman di file yang dilindungi sandi dan akan dihancurkan 5 tahun setelah akhir penelitian.

\section{APA SAJAKAH LUARAN DARI PROYEK INI?}

Informasi hanya akan dilaporkan dalam bentuk gabungan sebagai bagian dari laporan Magister saya. Ringkasan hasil penelitian ini dapat dipublikasikan dalam jurnal akademik atau profesional dan / atau dipresentasikan di konferensi profesional atau akademik. Data yang dikumpulkan juga dapat digunakan untuk penelitian lebih lanjut, seperti disertasi Doktoral. Dapat diyakinkan bahwa nama Anda akan dirahasiakan, dan bahwa setiap informasi atau pendapat yang bisa dilacak pada Anda tidak akan dilaporkan.

\section{JIKA ANDA MEMILIKI PERTANYAAN ATAU MASALAH, SIAPA YANG DAPAT ANDA HUBUNGI?}

Untuk pertanyaan terkait etika: AProf Susan Corbett, email susan.corbett@vuw.ac.nz, telepon +64-4-463 5480). Untuk pertanyaan lain hubungi:

MAHASISWA:

Nama: Anya Safira

Alamat email universitas:

safiraanya@myvuw.ac.nz
Pembimbing:

Prof. Kim Fam

Dosen

School of Marketing \& International Business

044636459

kim.fam@vuw.ac.nz 


\title{
Appendix 3. Participant Consent Form (English)
}

\author{
VICTORIA UNIVERSITY OF WELLINGTON \\ Te Whare Wānanga o te Ūpoko o te Ika a Māui

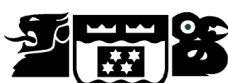 \\ School of Marketing and International Business \\ CONSENT FORM TO PARTICIPATE IN THE INTERVIEW \\ Perceptions of Islamic Advertising Held By Indonesian Muslims
}

- I have been provided with adequate information relating to the nature and objectives of this research project,

- I have understood this information and have been given the opportunity to seek further clarification or explanations,

- I understand that I will be participating in an audio recorded interview,

- I understand that I may withdraw from this study up to seven days of completing the interview, and any data that I have provided will be returned to me or destroyed,

- I understand that the researcher and supervisor will have access to the raw data but my name will be changed beforehand to maintain confidentiality,

- I understand that any information or opinions I provide will be kept confidential and reported only in an aggregated/non-attributable form,

- I understand that the results will be used for a Masters report and summary results of this survey may be published in academic or professional journals and/ or presented at professional or academic conferences. I also understand that the data may be used for further research, such as a Doctorate dissertation, but that my name will have been changed, and no identifiable information that is traceable to me will be included,

- I understand that when this research is completed, the raw data obtained will be destroyed after 5 years,

Signature of participant

Date:

Name of participant

Please provide your email if you would like a summary of the research report. Contact details: 


\title{
Appendix 4. Participant Consent Form (Indonesian)
}

\author{
VICTORIA UNIVERSITY OF WELLINGTON \\ Te Whare Wānanga o te Ūpoko o te Ika a Māui

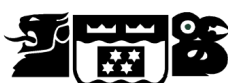 \\ School of Marketing and International Business

\section{FORMULIR PERSETUJUAN UNTUK BERPARTISIPASI DALAM WAWANCARA Persepsi Muslim Indonesia terhadap Iklan yang Islami}

- Saya telah diberikan informasi yang cukup terkait sifat dan tujuan dari proyek penelitian ini,

- Saya telah memahami informasi tersebut dan telah diberi kesempatan untuk mendapatkan klarifikasi atau penjelasan lebih lanjut,

- Saya mengerti bahwa saya akan berpartisipasi dalam sebuah wawancara audio yang direkam,

- Saya mengerti bahwa saya dapat mengundurkan diri dari penelitian ini hingga tujuh hari setelah selesainya wawancara, dan data yang saya berikan akan dikembali kan ke saya atau dihancurkan,

- Saya mengerti bahwa peneliti dan pembimbing akan memiliki akses ke data mentah tetapi nama saya akan diubah terlebih dahulu untuk menjaga kerahasiaan,

- Saya mengerti bahwa setiap informasi atau opini yang saya berikan akan dirahasiakan dan dilaporkan hanya dalam bentuk agregat/tidak dapat dilacak,

- Saya mengerti bahwa hasilnya akan digunakan untuk laporan Magister dan hasil ringkasan wawancara ini dapat dipublikasikan dalam jurnal akademik atau profesional dan / atau dipresentasikan di konferensi profesional atau akademis. Saya juga memahami bahwa data tersebut dapat digunakan untuk penelitian lebih lanjut, seperti disertasi Doktoral, tetapi nama saya akan diubah, dan tidak akan ada informasi identitas yang dapat dilacak ke saya,

- Saya mengerti bahwa ketika penelitian ini selesai, data mentah yang diperoleh akan dihancurkan setelah 5 tahun,

Tanda tangan partisipan

Tanggal:

Nama partisipan

Silakan tuliskan alamat email Anda jika ingin mendapatkan ringkasan hasil penelitian ini. 


\section{Appendix 5. Semi-Structured Interview Guide}

Semi-structured interviews require a certain interview protocol to serve as a guideline during the interviews. The specific questions that will be discussed during the interviews include:

1. Do you like to examine advertisements (ads)?

2. What kind of ads do you pay attention to? Which media?

3. What is an example of an ad that you like? Why?

4. Which parts of the ad do you like?

5. How do you feel or what do you do when you see an ad that you like?

6. What is an example of an ad that you dislike? Why?

7. Which parts of the ad do you dislike?

8. How do you feel or what do you do when you see an ad that you dislike?

9. What do you think are the purposes of an ad?

10. Do you think the ads you see achieve those purposes?

11. What considerations should companies have when developing ads in Indonesia?

12. Are there any specific elements, which should or should not be included?

13. Do you think your considerations would be different to other people's? Why?

14. What has influenced your way of thinking?

15. How would you describe yourself? Do you have specific values that you hold important?

16. What goes through your mind when I mention "Islamic advertising"?

17. What do you think makes an ad Islamic?

18. Is it important for an ad to be Islamic?

19. If so, do all ads have to Islamic or only specific ones?

20. Have you seen any examples of Islamic ads in Indonesia?

21. What do you think when you watch an Islamic ad? What are your feelings or reactions? 


\section{Appendix 6. Elements of Islamic Advertising}

Below is a table of the most frequent words used to describe Islamic advertising:

\begin{tabular}{lrr}
\hline Word & Count & Weighted Percentage (\%) \\
\hline hijab & 46 & $12.47 \%$ \\
\hline good & 37 & $10.03 \%$ \\
\hline islam & 31 & $8.40 \%$ \\
\hline halal & 28 & $7.59 \%$ \\
\hline wear & 26 & $7.05 \%$ \\
\hline wardah & 20 & $5.42 \%$ \\
\hline values & 19 & $5.15 \%$ \\
\hline Muslims & 17 & $4.61 \%$ \\
\hline content & 13 & $3.52 \%$ \\
\hline Muslim & 13 & $3.52 \%$ \\
\hline ramadhan & 13 & $3.52 \%$ \\
\hline target & 12 & $3.25 \%$ \\
\hline eid & 10 & $2.71 \%$ \\
\hline certain & 9 & $2.44 \%$ \\
\hline polite & 9 & $2.44 \%$ \\
\hline powder & 9 & $2.44 \%$ \\
\hline religion & 9 & $2.44 \%$ \\
\hline clothes & 8 & $2.17 \%$ \\
\hline food & 8 & $2.17 \%$ \\
\hline kid & 8 & $2.17 \%$ \\
\hline kids & 8 & $2.17 \%$ \\
\hline market & 8 & $2.17 \%$ \\
\hline story & 8 & $2.17 \%$ \\
\hline & &
\end{tabular}

